\title{
Actuele arbeidsmarktinformatie voor de regio Rijnmond
}

Citation for published version (APA):

Hoevenberg, J., Willems, E. J. T. A., \& de Grip, A. (1993). Actuele arbeidsmarktinformatie voor de regio Rijnmond. Researchcentrum voor Onderwijs en Arbeidsmarkt, Faculteit der Economische

Wetenschappen. ROA Reports No. 5 https://doi.org/10.26481/umarep.1993005

Document status and date:

Published: 01/01/1993

DOI:

10.26481/umarep.1993005

Document Version:

Publisher's PDF, also known as Version of record

\section{Please check the document version of this publication:}

- A submitted manuscript is the version of the article upon submission and before peer-review. There can be important differences between the submitted version and the official published version of record.

People interested in the research are advised to contact the author for the final version of the publication, or visit the DOI to the publisher's website.

- The final author version and the galley proof are versions of the publication after peer review.

- The final published version features the final layout of the paper including the volume, issue and page numbers.

Link to publication

\footnotetext{
General rights rights.

- You may freely distribute the URL identifying the publication in the public portal. please follow below link for the End User Agreement:

www.umlib.nl/taverne-license

Take down policy

If you believe that this document breaches copyright please contact us at:

repository@maastrichtuniversity.nl

providing details and we will investigate your claim.
}

Copyright and moral rights for the publications made accessible in the public portal are retained by the authors and/or other copyright owners and it is a condition of accessing publications that users recognise and abide by the legal requirements associated with these

- Users may download and print one copy of any publication from the public portal for the purpose of private study or research.

- You may not further distribute the material or use it for any profit-making activity or commercial gain

If the publication is distributed under the terms of Article $25 \mathrm{fa}$ of the Dutch Copyright Act, indicated by the "Taverne" license above, 
ACTUELE ARBEIDSMARKTINFORMATIE

VOOR DE REGIO RIJNMOND

ROA-R-1993/5

J. Hoevenberg

E.J.T.A. Willems

A. de Grip

RESEARCHCENTRUM VOOR ONDERWIJS EN ARBEIDSMARKT

Rijksuniversiteit Limburg

Faculteit der Economische Wetenschappen

Maastricht, oktober 1993 


\section{CIP-GEGEVENS KONINKLIJKE BIBLIOTHEEK, DEN HAAG}

Hoevenberg, J.

Actuele arbeidsmarktinformatie voor de regio Rijnmond/J. Hoevenberg, E.J.T.A. Willems, A. de Grip. - Maastricht: Researchcentrum voor Onderwijs en Arbeidsmarkt, Rijksuniversiteit Limburg, Faculteit der Economische Wetenschappen. - (ROA-R-1993/5)

Met lit. opg.

ISBN 90-5321-108-X

Trefw.: arbeidsmarkt; Rijnmond. 


\section{INHOUDSOPGAVE}

Bladzijde

VOORWOORD

1. INLEIDING 1

2. WERKGELEGENHEIDSSTRUCTUUR 4

2.1. Inleiding 4

2.2. Sectorstructuur 4

2.3. Beroepenstructuur 5

2.4. Opleidingenstructuur $\quad 7$

3. DE POSITIE VAN VROUWEN EN ALLOCHTONEN OP DE ARBEIDSMARKT 11

3.1. De positie van vrouwen op de arbeidsmarkt 11

$\begin{array}{ll}\text { 3.2. De positie van allochtonen op de arbeidsmarkt } & 17\end{array}$

4. DE ARBEIDSMARKTPOSITIE VAN SCHOOLVERLATERS 22

4.1. Inleiding 22

4.2. Werkloosheid 23

4.3. Kwalitatieve aansluiting onderwijs-arbeidsmarkt 25

4.4. De arbeidsmarktpositie van vrouwelijke schoolverlaters $\quad 27$

4.5. De arbeidsmarktpositie van allochtone schoolverlaters 28

5. FORENSENSTROMEN 30

5.1. Inleiding 30

5.2. Forensenstromen per bedrijfssector 31

5.3. Forensenstromen per opleidingsniveau 32

6. ROTTERDAM NADER BELICHT 34

6.1. Inleiding $\quad 34$

6.2. Opleidingsniveau in Rotterdam 34

6.2. Forensenstromen $\quad 35$

$\begin{array}{lll}\text { 7. BESLUIT } & 38\end{array}$

$\begin{array}{ll}\text { LITERATUUR } & 41\end{array}$

BIJLAGE A. DEFINITIES REGIO RIJNMOND

BIJLAGE B. OVERZICHT VAN BEDRIJFSSECTOREN

BIJLAGE C. STATISTISCH SUPPLEMENT 



\section{VOORWOORD}

Voor het uitvoeren van een adequaat arbeidsmarktbeleid is de beschikbaarheid van voldoende gedetailleerde arbeidsmarktinformatie onontbeerlijk. Het Researchcentrum voor Onderwijs en Arbeidsmarkt (ROA) heeft het informatiesysteem onderwijs-arbeidsmarkt ontwikkeld, op basis waarvan op landelijk niveau een veelheid aan arbeidsmarktinformatie kan worden gepresenteerd. Met behulp van de gegevens van dit informatiesysteem wordt een beeld verkregen van de actuele werkgelegenheidsstructuur, verbijzonderd naar bedrijfssector, beroep en opleiding. Daarnaast bevat dit landelijke informatiesysteem enkele arbeidsmarktindicatoren ('risicoindicatoren'; zie ROA, 1992) en middellange-termijn beroeps- en opleidingsprognoses op een vrij gedesaggregeerd niveau.

Dit landelijke informatiesysteem vormt een geschikt raamwerk om ook op regionaal niveau gegevens te verzamelen. In dit onderzoek, dat is verricht in opdracht van het Ontwikkelingsbedrijf Rotterdam (OBR), wordt met name op basis van de gegevens afkomstig uit de Enquête Beroepsbevolking van het Centraal Bureau voor de Statistiek (CBS), een beeld geschetst van de actuele arbeidsmarktsituatie in de regio Rijnmond. Evenals in het landelijke informatiesysteem zijn de gegevens daarbij verbijzonderd naar bedrijfssector, beroep en opleiding. Daarnaast zullen enkele specifieke thema's nader worden belicht. Het gaat daarbij achtereenvolgens om de positie van vrouwen, allochtonen en schoolverlaters op de arbeidsmarkt. Van de schoolverlatersinformatie is gebruik gemaakt van de resultaten van het onderzoek Registratie Uitstroom en Bestemming van Schoolverlaters (RUBS). Tenslotte wordt expliciet ingegaan op de omvang en de aard van het forensisme en wordt meer expliciet ingegaan op de werkgelegenheidsstructuur in de stad Rotterdam.

Het onderzoek is uitgevoerd door drs. J. Hoevenberg, drs. E.J.T.A. Willems (projectleider) en dr. A. de Grip. Drs. R.J.P. Dekker was betrokken bij de verzameling van de gegevens en M.E.C. Reiners assisteerde bij de verwerking van deze gegevens. Vanuit het OBR, Unit Arbeidsmarkt en Werkgelegenheid, is het onderzoek begeleid door ir. W.A. Hamel. 



\section{INLEIDING}

\section{Achtergrond}

Eén van de belangrijkste doelstellingen van het Ontwikkelingsbedrijf Rotterdam (OBR) is het stimuleren van de economische groei en de werkgelegenheid in de regio. Dit bepaalt tevens het kader van de taken van de unit Arbeidsmarkt en Werkgelegenheid van het Ontwikkelingsbedrijf. Een groot manco bij de concrete invulling van dit beleid is momenteel het ontbreken van een cijfermatig inzicht in de actuele arbeidsmarktsituatie en de op lange termijn te verwachten ontwikkelingen. De beschikbaarheid van goede en voldoende gedetailleerde arbeidsmarktinformatie is echter een noodzakelijke randvoorwaarde voor het formuleren en uitvoeren van een deugdelijk werkgelegenheids-, c.q. arbeidsmarktbeleid (zie bijvoorbeeld ook Heijke, 1993 en De Grip en Heijke, 1993).

Het is daarbij van belang dat de informatie een regionaal karakter heeft, omdat de regio Rijnmond op hoofdpunten afwijkt van de Nederlandse economische en werkgelegenheidsstructuur. Een typisch kenmerk van de economische structuur van de regio Rijnmond wordt vanzelfsprekend gevormd door de Rotterdamse haven. Zo vindt meer dan $60 \%$ van het volume van alle Nederlandse import en export via Rijnmond plaats. Indien alleen naar de over zee aangevoerde en afgevoerde goederen wordt gekeken is dit zelfs meer dan 70\% (CBS, 1991). Derhalve is er een oververtegenwoordiging van bedrijfsvestigingen in de sectoren binnenvaart, hulpbedrijven van het vervoer en spoor- en wegvervoer. Daarnaast neemt de regio een dominerende positie in in de olie-overslag'. Deze spilfunctie van Rijnmond in de aanvoer, afvoer en overslag van goederen wordt vanzelfsprekend weerspiegeld in de bedrijfssectorstructuur in de regio. Van alle ondernemingen in de zeevaart is bijna de helft in Rijnmond gevestigd. Daarentegen wordt slechts $31 \%$ van de totale oppervlakte voor agrarische doeleinden gebruikt, terwijl dit landelijk gezien maar liefst $64 \%$ is (CBS, 1991).

\section{Onderzoeksopzet}

Om in de bovengenoemde lacune in de beschikbaarheid van adequate arbeidsmarktinformatie te voorzien, zijn de voor dit onderzoek noodzakelijke gegevens verzameld en geanalyseerd. De benodigde gegevens zijn afkomstig van de Enquête Beroepsbevolking (EBB), die sinds 1987 jaarlijks door het Centraal Bureau voor de Statistiek (CBS) wordt gehouden. De EBB is gebaseerd op een ongeveer 1\%-steekproef. De enquêteresultaten worden vervolgens opgehoogd tot 'werkelijke' aantallen. De werkgelegenheidsinformatie zal worden verbijzonderd naar bedrijfssector, beroep en opleiding en heeft vooral betrekking op de degenen die werken in

1. Zie voor meer details CBS (1992). 
de regio Rijnmond ${ }^{2}$. Daarbij wordt uitgegaan van de gemiddelde cijfers over de jaren 1989$1991^{3}$. Ten eerste heeft dit als voordeel dat de informatie 'harder' is dan wanneer wordt uitgegaan van de cijfers voor één bepaald jaar. Ten tweede maakt dit het mogelijk om meer informatie te krijgen. Het CBS stelt namelijk bepaalde voorwaarden aan het publiceren van de EBB-gegevens, in verband met de betrouwbaarheid en de privacy-gevoeligheid van de gegevens. Voor drie- en tweejaarsgemiddelden wordt een ondergrens van respectievelijk 2.000 en 3.000 personen per 'cel' gehanteerd. Daarentegen geldt bij jaarcijfers een ondergrens van 5.000 personen ${ }^{4}$. Bovendien is het van belang om op te merken dat de gegevens zijn gebaseerd op de nieuwe definitie van de beroepsbevolking, dat wil zeggen dat alleen degenen met een wekelijkse arbeidstijd van tenminste 12 uur tot de werkzame bevolking worden gerekend (zie ook CBS, 1993).

Naast de op de EBB gebaseerde arbeidsmarktdata wordt ook gebruik gemaakt van de uitkomsten van de schoolverlatersenquête RUBS (Registratie Uitstroom en Bestemming van Schoolverlaters). De meest recente gegevens van RUBS zijn gebaseerd op een enquête onder ruim 44.000 schoolverlaters van het schooljaar 1990/1991 over de volle breedte van het Algemeen Voortgezet Onderwijs (AVO), Lager Beroepsonderwijs (LBO) ${ }^{5}$ en Middelbaar Beroepsonderwijs (MBO) (zie Wieling, Van de Loo en Van der Velden, 1993). De gegevens daarvoor zijn verzameld in het voorjaar van 1992, dat wil zeggen bijna een jaar na het verlaten van de opleiding. Met behulp van de RUBS-enquête kan een beter beeld worden verkregen van de directe aans/uitingsproblemen van de schoolverlaters op de arbeidsmarkt. Daarnaast kan op basis van deze gegevens een beeld worden verkregen van de werkloosheid onder schoolverlaters in de regio. Op basis van de EBB is op dit moment helaas geen informatie over de werkloosheid in de regio Rijnmond beschikbaar.

Tot nu toe is zonder nadere aanduiding gesproken van de regio Rijnmond. Er bestaan echter verschillende definities van deze regio. In dit onderzoek behoren tot de regio Rijnmond de

2. De 'werkregio' van een respondent is bepaald aan de hand van de gemeente waar men normaal de werkzaamheden verricht. In een aantal gevallen is dit echter onbekend, c.q. er is geen antwoord op de desbetreffende vraag gegeven. In dat geval wordt uitgegaan van de vestigingsgemeente van het bedrijf waar men werkzaam is. Is ook dit onbekend dan wordt noodgedwongen teruggegrepen op de woonplaats van de respondent. De gevolgde procedure zou kunnen betekenen dat de pendel van werkenden in lichte mate wordt onderschat.

3. Gegevens over 1992 waren ten tijde van de verzameling van de benodigde data nog niet beschikbaar. Gegevens verbijzonderd naar opleiding zijn alleen beschikbaar voor de jaren 1990 en 1991. Eerdere opleidingsgegevens op basis van de Arbeidskrachtentelling (AKT) zijn slechts beschikbaar tot 1985. Deze cijfers zijn echter door onder meer verschillen in de opzet tussen AKT en EBB minder goed vergelijkbaar met de in dit rapport gepresenteerde gegevens.

4. In het geval van driejaarsgemiddelden vindt een afronding op 500-tallen plaats; in de beide andere gevallen moet op 1.000-tallen worden afgerond.

5. Per 1 augustus 1992 is het LBO vervangen door het Voorbereidend Beroepsonderwijs (VBO). Aangezien er momenteel nog geen VBO-schoolverlaters op de arbeidsmarkt actief zijn, zal in dit rapport nog de term LBO worden gehanteerd. 
gemeenten die zijn aangesloten bij het Overleg Orgaan Rijnmond (OOR) ${ }^{6}$. In bijlage A wordt aangegeven welke gemeenten dit zijn. Tevens zijn in deze bijlage drie andere definities van de regio Rijnmond opgenomen, zodat eenvoudig kan worden nagegaan wat de verschillen tussen de gebieden zijn.

\section{Opzet van het rapport}

De verdere opbouw van dit rapport is als volgt. In hoofdstuk 2 wordt een beeld geschetst van de actuele structuur van de werkgelegenheid in de regio Rijnmond. Daarbij zal een onderscheid worden gemaakt tussen de bedrijfssectorstructuur, de beroepenstructuur en de opleidingenstructuur. Bovendien wordt de situatie voor de regio Rijnmond vergeleken met de rest van Nederland. Bij de interpretatie van deze verschillen moet wel worden beseft dat de resultaten zijn gebaseerd op een voor dit doel vrij kleine steekproef ${ }^{7}$. Hoofdstuk 3 gaat vervolgens in op de positie van een tweetal specifieke groepen op de arbeidsmarkt: vrouwen en allochtonen. Ook in hoofdstuk 4 wordt de arbeidsmarktpositie van een specifieke groep nader belicht. Hier betreft het de aansluiting tussen onderwijs en arbeidsmarkt voor schoolverlaters. Daarna komt in hoofdstuk 5 het forensisme aan bod. In hoofdstuk 6 wordt expliciet aandacht besteed aan de positie van de stad Rotterdam. Het rapport wordt in hoofdstuk 7 met enkele conclusies afgesloten. Tevens zullen in dit slothoofdstuk voorstellen voor mogelijke vervolgtrajecten van dit onderzoek worden gedaan.

6. Ten tijde van de dataverzameling voor dit onderzoek behoorde de gemeente Bleiswijk nog niet tot het OOR en derhalve is deze gemeente niet tot de regio Rijnmond gerekend.

7. Zie hiervoor bijvoorbeeld tabel 12 van de CBS-publikatie Enquête Beroepsbevolking 1992 (CBS, 1993, blz. 27). 


\section{WERKGELEGENHEIDSSTRUCTUUR}

\subsection{Inleiding}

Voor de ontwikkeling van de werkgelegenheid in de regio Rijnmond zijn de sector-, beroepen- en opleidingenstructuur van groot belang. Als een landelijke groeisector sterk in de regio is vertegenwoordigd, zal de regionale werkgelegenheidsontwikkeling doorgaans eveneens gunstig zijn, al bestaat vanzelfsprekend ook de mogelijkheid dat een dergelijke landelijke groeisector in de regio zelf minder floreert. Wanneer echter de economisch 'zwakkere' sectoren sterk in de regio zijn verankerd, betekent dit waarschijnlijk dat ook de ontwikkeling van de werkgelegenheid in de regio achter zal blijven bij de landelijke ontwikkeling. Verder bepaalt de sectorstructuur, vanzelfsprekend, in hoge mate de beroepenstructuur van de werkgelegenheid. Ook de opleidingenstructuur van de werkzame bevolking zal in belangrijke mate door de sector- en beroepenstructuur worden bepaald. In dit hoofdstuk wordt een globaal overzicht gegeven van de werkgelegenheidsstructuur van de in Rijnmond werkzame beroepsbevolking. Er is alleen een overzicht van de werkzame beroepsbevolking mogelijk, daar het CBS momenteel geen gegevens over de geregistreerde werkloosheid in de regio Rijnmond verstrekt.

De verdere opzet van dit hoofdstuk is als volgt. Eerst wordt in paragraaf 2.2 aandacht besteed aan de sectorstructuur van de werkgelegenheid. Paragraaf 2.3 gaat vervolgens in op de beroepenstructuur, terwijl in paragraaf 2.4 de opleidingenstructuur aan de orde komt. Daarbij wordt telkens het beeld voor de regio Rijnmond afgezet tegen de landelijke situatie.

\subsection{Sectorstructuur}

In tabel 2.1 wordt weergegeven hoe de werkgelegenheid in de regio Rijnmond over de verschillende bedrijfssectoren ${ }^{8}$ is verdeeld. Daarbij is tevens aangegeven hoe deze cijfers zich verhouden tot de landelijke sectorale werkgelegenheidsstructuur. Uit de tabel kan worden opgemaakt dat de in de regio Rijnmond werkzame bevolking ongeveer $8 \%$ van de totale werkzame bevolking van geheel Nederland uitmaakt. Verder blijkt uit de tabel dat de sectorstructuur, zoals verwacht mocht worden, op een aantal punten sterk afwijkt van de landelijke structuur. Zo is het percentage van het totaal aantal werkenden dat werkzaam is in de bedrijfssector 'Land-, tuin- en bosbouw, visserij' aanzienlijk lager dan het landelijk gemiddelde. Ook is het niet verrassend dat de bedrijfssectoren 'Delfstoffenwinning en aardolie industrie' en 'Vervoer en communicatie' meer dan evenredig in de regio zijn vertegenwoordigd. Voor deze beide sectoren geldt dat respectievelijk maar liefst $16 \%$ en $32 \%$ van de landelijke werkgelegenheid in deze sectoren zich in de regio Rijnmond bevindt.

Opvallend is wel het relatief lage aantal arbeidskrachten dat in de sector 'Overige industrie' werkt. Het verschil bedraagt 4\%-punt met het landelijke cijfer. Daarnaast blijken de bedrijfs-

8. In bijlage B wordt een overzicht gegeven van de in dit rapport onderscheiden bedrijfssectoren, waarbij tevens de CBS-classificatie volgens de Standaard Bedrijfsindeling (SBI) is opgenomen. 
sectoren 'Metaalindustrie en openbare nutsbedrijven' en 'Overheid en onderwijs' in de regio Rijnmond enigszins te zijn ondervertegenwoordigd, terwijl de werkgelegenheid in de sector 'Overige tertiaire dienstverlening' verhoudingsgewijs groot is.

Tabel 2.1. Aantal en percentage werkenden naar bedrijfssector in de regio Rijnmond en in geheel Nederland, gemiddelde 1989-1991

Bedrijfssector Rijnmond Nederland aantal werkenden $\quad \% \quad$ aantal werkenden $\quad \%$

Land-, tuin- en bosbouw, visserij

Chemische industrie

Metaalindustrie en openbare nutsbedrijven

Delfstoffenwinning en aardolie industrie

Overige industrie

Bouwnijverheid en bouwinstallatiebedrijven

Groothandel en reparatiebedrijven

Detailhandel en horeca

Vervoer en communicatie

Bank- en verzekeringswezen

Overige tertiaire dienstverlening

Overheid en onderwijs

Overige kwartaire dienstverlening

Totaal

\subsection{0}

14.000

33.500

7.000

19.000

30.000

36.500

41.000

55.000

22.000

38.000

56.500

80.000

442.500

100

261.500

5

137.000

563.000

22.000

428.500

394.000

434.500

564.500

354.000

210.500

381.000

859.000

1.005 .500

2

Bron: CBS/ROA

\subsection{Beroepenstructuur}

Zoals gezegd, bepaalt de sectorstructuur in belangrijke mate de beroepenstructuur van de werkgelegenheid. In deze paragraaf zijn de beroepen ingedeeld volgens de ROA-beroepenclassificatie 1990, welke is gestructureerd volgens een viercijferige code. Het eerste cijfer, dat een onderscheid aanbrengt naar beroepssectoren, verwijst naar de opleidingsrichting van de werkenden. Het tweede cijfer (beroepstakken) geeft een verdere verbijzondering naar de branche waarin de desbetreffende beroepsbeoefenaren hoofdzakelijk werkzaam zijn, terwijl het derde cijfer (beroepssegmenten) vervolgens een onderscheid maakt naar het (mediaan) opleidingsniveau van de werkenden. Het vierde cijfer is slechts een volgnummer. Met de viercijferige code worden 93 beroepsklassen onderscheiden (voor verdere details zie Van de Loo, Dekker en de Grip, 1992).

Tabel 2.2 geeft een overzicht van de verdeling van de werkgelegenheid in de verschillende beroepssectoren. De beroepenstructuur in de regio Rijnmond wijkt slechts op enkele punten af van de landelijke beroepenstructuur. In de 'Agrarische beroepen' is de werkgelegenheid in de regio Rijnmond 3\%-punt lager dan de landelijke werkgelegenheid. Dit hangt vanzelfsprekend samen met de ondervertegenwoordiging van de bedrijfssector 'Land-, tuin- en bosbouw, visserij' in de regio Rijnmond die in de vorige paragraaf is geconstateerd. De 'Economisch-administra- 
$-6-$

tieve beroepen' zijn in de regio Rijnmond sterk vertegenwoordigd ten opzichte van de landelijke werkgelegenheid. Dit wordt waarschijnlijk veroorzaakt door de sterke positie van de bedrijfssectoren 'Vervoer en communicatie' en de 'Overige tertiaire dienstverlening' in de regio. Gezien de ondervertegenwoordiging van de sector 'Overige industrie' in de regio zou men verwachten dat het aandeel arbeidskrachten in de beroepssector 'Technische, ambachts- en industrie beroepen' lager zou liggen dan het landelijke cijfer. Dit is echter niet het geval.

Tabel 2.2. Aantal en percentage werkenden naar beroepssector in de regio Rijnmond en in geheel Nederland, gemiddelde 1989-1991

\begin{tabular}{|c|c|c|c|c|c|}
\hline & beroepssector & $\begin{array}{l}\text { nmond } \\
\text { ntal werkenden }\end{array}$ & $\%$ & $\begin{array}{l}\text { Nederland } \\
\text { aantal werkenden }\end{array}$ & $\%$ \\
\hline 0 & Pedagogische beroepen & 22.000 & 5 & 296.000 & 5 \\
\hline 1 & Culturele beroepen & 4.000 & 1 & 76.500 & 1 \\
\hline 2 & Agrarische beroepen & 8.000 & 2 & 284.000 & 5 \\
\hline 3 & Technische, ambachts- en industrie beroepen & 127.000 & 29 & 1.651 .000 & 29 \\
\hline 4 & Transportberoepen & 33.000 & 7 & 328.000 & 6 \\
\hline 5 & Medische en paramedische beroepen & 30.500 & 7 & 389.500 & 7 \\
\hline 6 & Economisch-administratieve beroepen & 158.000 & 36 & 1.831 .000 & 32 \\
\hline 7 & Sociaal-culturele beroepen & 12.500 & 3 & 166.000 & 3 \\
\hline 8 & Verzorgende en dienstverlenende beroepen & 39.000 & 9 & 479.000 & 8 \\
\hline \multirow[t]{2}{*}{9} & Openbare orde- en veiligheidsberoepen & 7.000 & 2 & 95.000 & 2 \\
\hline & Totaal & 442.500 & 100 & 5.660 .000 & 100 \\
\hline
\end{tabular}

Bron: CBS/ROA

Tabel 2.3. Beroepsklassen die relatief sterk in de regio Rijnmond zijn vertegenwoordigd, gemiddelde 19891991

\begin{tabular}{|c|c|c|c|c|}
\hline $\begin{array}{l}\text { ROA- } \\
\text { code }\end{array}$ & beroepsklasse & $\begin{array}{l}\text { Rijnmond } \\
\text { aantal werkenden }\end{array}$ & $\begin{array}{l}\text { Nederland } \\
\text { aantal werkenden }\end{array}$ & $\begin{array}{l}\% \text { van he } \\
\text { totaal }\end{array}$ \\
\hline 4121 & Scheepsofficieren, loodsen, walinspecteurs & 3.000 & 8.000 & 38 \\
\hline 3511 & Produktiepersoneel chemische industrie & 5.000 & 28.500 & 18 \\
\hline 4321 & Vliegers, boordwerktuigkundigen, transport- & & & \\
\hline & dienstleiders & 5.000 & 29.000 & 17 \\
\hline 3622 & Middelbare (scheeps/werktuigkundigen e.a. & & & \\
\hline 3012 & $\begin{array}{l}\text { metaaikunaigen } \\
\text { Machinisten bouw en industrie }\end{array}$ & $\begin{array}{l}2.000 \\
4.000\end{array}$ & $\begin{array}{l}13.000 \\
31.000\end{array}$ & $\begin{array}{l}15 \\
13\end{array}$ \\
\hline 6121 & Administratief leidinggevenden & 5.000 & 43.000 & 12 \\
\hline 3023 & Technisch tekenaars & 4.000 & 37.500 & 11 \\
\hline 3914 & Loodgieters, sanitair-installateurs en & & & \\
\hline & -reparateurs & 5.000 & 45.500 & 11 \\
\hline $\begin{array}{l}3931 \\
5025\end{array}$ & $\begin{array}{l}\text { Architecten, geodeten e.a. hogere bouwkundigen } \\
\text { FFGG }\end{array}$ & 3.000 & 28.000 & 11 \\
\hline & logopedisten, pedicuren e.d. & 2.500 & 23.500 & 11 \\
\hline & Totaal & 442.500 & 5.660 .000 & 8 \\
\hline
\end{tabular}

Bron: CBS/ROA 
In bijlage $\mathrm{C}$ wordt een totaaloverzicht gegeven van de werkgelegenheid per ROA-beroepsklasse. In tabel 2.3 wordt een beeld geschetst van de tien beroepsklassen die in vergelijking met het landelijk gemiddelde sterk in de regio Rijnmond zijn vertegenwoordigd. In de tabel komt de positie van Rijnmond als distributiecentrum van Nederland duidelijk naar voren. Zo is maar liefst $40 \%$ van de totale Nederlandse werkgelegenheid in de beroepsklasse 'Scheepsofficieren, loodsen en walinspecteurs' geconcentreerd in de regio Rijnmond. Ook de beroepsklassen 'Vliegers, boordwerktuigkundigen, transportdienstleiders' en 'Middelbare (scheeps)werktuigkundigen e.a. metaalkundigen' zijn sterk in de regio vertegenwoordigd. Verder blijkt dat het aantal werkenden in de beroepsklasse 'Produktiepersoneel chemische industrie', met $18 \%$ van de totale landelijke werkgelegenheid in de desbetreffende beroepsklasse, relatief groot is. Dit hangt vanzelfsprekend samen met de sterke vertegenwoordiging van de sector 'Delfstoffen en aardolie-industrie' in de regio.

\subsection{Opleidingenstructuur}

Tabel 2.4 geeft een overzicht van het aantal werkenden per opleidingsniveau en het aandeel van degenen met de desbetreffende opleidingsachtergrond in de totale werkgelegenheid. De tabel laat zien dat de percentages werkenden, verbijzonderd naar opleidingsniveau in de regio Rijnmond, slechts marginaal afwijken van de landelijke percentages. Alleen het aantal 'ongeschoolden' (werkenden met uitsluitend basisonderwijs) ${ }^{9}$ ligt enigszins boven het landelijke cijfer. Het aantal werkenden MBO-ers blijft daarentegen in Rijnmond verhoudingsgewijs iets achter bij de rest van Nederland.

Tabel 2.4. Aantal en percentage werkenden naar opleidingsniveau in de regio Rijnmond en in geheel Nederland, gemiddelde 1990-1991

\begin{tabular}{lrrrr} 
Opleidingsniveau & $\begin{array}{l}\text { Rijnmond } \\
\text { aantal werkenden }\end{array}$ & $\begin{array}{l}\text { Nederland } \\
\text { aantal werkenden }\end{array}$ & $\%$ \\
\hline Basisonderwijs & 52.000 & 12 & 597.000 & 10 \\
MAVO en onderbouw HAVO/VWO & 32.000 & 7 & 396.000 & 7 \\
LBO & 80.000 & 18 & 1.029 .000 & 18 \\
HAVO/VWO & 25.000 & 6 & 267.000 & 5 \\
MBO & 161.000 & 36 & 2.172 .000 & 38 \\
HBO & 71.000 & 16 & 871.000 & 15 \\
WO & 28.000 & 6 & 390.000 & 7 \\
& & & & \\
Totaal & 449.000 & 100 & 5.740 .000 & 100 \\
\hline
\end{tabular}

\section{Bron: $\mathrm{CBS} / \mathrm{ROA}$}

Ook tabel 2.5, waarin de opleidingstypen zijn weergegeven die in vergelijking met het landelijke beeld in de regio zijn oververtegenwoordigd, laat zien dat de regio Rijnmond het distributiecentrum van Nederland is. Uit de tabel blijkt dat maar liefst ruim een kwart van de werkzame

9. Dit zijn behalve de oudere arbeidskrachten vooral drop-outs van het voortgezet onderwijs. 
bevolking in Nederland met een 'HBO Vervoer' opleiding, circa $20 \%$ van de werkzame bevolking met de opleiding 'MBO Haven \& Vervoer' en ruim $15 \%$ van de arbeidskrachten met 'LBO Haven \& Vervoer' werkzaam is in de regio Rijnmond. In deze tabel is verder opvallend dat de werkgelegenheid voor arbeidskrachten met 'HBO Technisch Laboratorium' in de regio Rijnmond relatief groot is. Waarschijnlijk hangt dit samen met de sterke vertegenwoordiging van de chemische industrie in de regio.

Tabel 2.5. Opleidingstypen die relatief sterk in de regio Rijnmond zijn vertegenwoordigd, gemiddelde 1990 1991

\begin{tabular}{llrrr}
\hline $\begin{array}{l}\text { SOI- } \\
\text { code }\end{array}$ & opleidingstype & $\begin{array}{l}\text { Rijnmond } \\
\text { aantal werkenden }\end{array}$ & $\begin{array}{l}\text { Nederland } \\
\text { aantal werkenden }\end{array}$ & $\begin{array}{l}\% \text { van het } \\
\text { totaal }\end{array}$ \\
\hline $541-549$ & HBO Vervoer & & & 27 \\
$441-449$ & MBO Haven \& Vervoer & 9.000 & 26.000 & 20 \\
552 & HBO Medisch Laboratorium & 9.000 & 44.000 & 17 \\
$341-349$ & LBO Haven \& Vervoer & 3.000 & 18.000 & 16 \\
531 & HBO Technisch Laboratorium & 6.000 & 37.000 & 10 \\
$361-369$ & LBO Economisch-Administratief & 3.000 & 29.000 & 9 \\
401 & Bovenbouw HAVO/VWO & 13.000 & 134.000 & 9 \\
$491-494$ & MBO Politie \& Defensie & 25.000 & 267.000 & 9 \\
466 & MBO Bestuurlijk & 8.000 & 87.000 & 9 \\
$000,111,201$ & Basisonderwijs & 4.000 & 44.000 & 8 \\
& Totaal & 52.000 & 597.000 & \\
\hline
\end{tabular}

Bron: CBS/ROA

Tabel 2.6 laat zien dat het aandeel van de ongeschoolden (degenen met uitsluitend basisonderwijs) in de werk-gelegenheid in de regio Rijnmond binnen alle bedrijfssectoren groter of gelijk is aan het landelijke aandeel van deze groep in de werkgelegenheid van de desbetreffende sector. Vooral in de sector 'Detailhandel en horeca' zijn, in vergelijking met de landelijke situatie, relatief veel ongeschoolden werkzaam. Ook in de sectoren 'Metaalindustrie en openbare nutsbedrijven', 'Overige industrie', 'Bouwnijverheid en bouwinstallatiebedrijven' en 'Overige kwartaire dienstverlening' werken, vergeleken met de landelijke situatie, relatief veel ongeschoolden. In deze vijf bedrijfssectoren is ruim $60 \%$ van alle ongeschoolden in de regio Rijnmond werkzaam. De sector 'Overige kwartaire dienstverlening' biedt daarbij werkgelegenheid aan $17 \%$ van alle ongeschoolden in de regio Rijnmond, terwijl dit landelijk slechts $13 \%$ is. Echter, vooral in de sector 'Vervoer en communicatie' is er relatief gezien veel werk voor ongeschoolde arbeidskrachten. In Rijnmond is $15 \%$ van alle ongeschoolden in deze sector werkzaam, terwijl dit landelijk slechts $9 \%$ is (zie tabel C.13 van bijlage C). Overigens is dit in overeenstemming met de sterke werkgelegenheidspositie van deze sector in de regio Rijnmond (zie tabel 2.1).

Uit tabel 2.6 blijkt verder dat een relatief groot aantal werkenden in de sector 'Bank- en verzekeringswezen' een opleiding MAVO of onderbouw HAVO/VWO heeft genoten in de regio Rijnmond. Van alle werkenden in deze sector in de regio Rijnmond heeft $14 \%$ een dergelijke opleiding, tegenover slechts $11 \%$ in geheel Nederland. In de bedrijfssector 'Land-, tuin- en 
bosbouw, visserij' ligt het percentage werkenden met een LBO-opleiding in de regio hoger dan het landelijke cijfer. Ook in de sectoren 'Metaalindustrie en openbare nutsbedrijven' en 'Overige kwartaire dienstverlening' is het aantal werkenden met een opleiding op LBO-niveau in de regio Rijnmond relatief groot. In beide sectoren ligt het percentage werkenden met deze opleiding in de regio Rijnmond $4 \%$-punt hoger dan landelijk het geval is.

Tabel 2.6. Percentage werkenden naar opleidingsniveau per bedrijfssector in de regio Rijnmond en in geheel Nederland, gemiddelde 1990-1991

Bedrijfssector

\begin{tabular}{|c|c|c|c|c|c|}
\hline \multicolumn{6}{|c|}{ Opleidingsniveau } \\
\hline 1 & 2 & 3 & 4 & 5 & 6 \\
\hline$\%$ & $\%$ & $\%$ & $\%$ & $\%$ & $\%$ \\
\hline
\end{tabular}

\section{Rijnmond}

Land-, tuin- en bosbouw, visserij

Chemische industrie

Metaalindustrie en openbare nutsbedrijven

Delfstoffenwinning en aardolie industrie

Overige industrie

Bouwnijverheid en bouwinstallatiebedrijven

Groothandel en reparatiebedrijven

Detailhandel en horeca

Vervoer en communicatie

Bank- en verzekeringswezen

Overige tertiaire dienstverlening

Overheid en onderwijs

Overige kwartaire dienstverlening

Totaal

$\begin{array}{rrrrrrr}- & - & 43 & - & - & - & 7.000 \\ - & - & 21 & - & 43 & 21 & 14.000 \\ 18 & - & 29 & - & 38 & 9 & 34.000 \\ - & - & - & - & 57 & - & 7.000 \\ 21 & - & 21 & - & 37 & 16 & 19.000 \\ 19 & - & 32 & - & 35 & - & 31.000 \\ 13 & 8 & 18 & 8 & 39 & 13 & 38.000 \\ 18 & 13 & 23 & 8 & 35 & - & 40.000 \\ 15 & 11 & 22 & 5 & 35 & 13 & 55.000 \\ - & 14 & - & 14 & 41 & 23 & 22.000 \\ - & 7 & 10 & 10 & 32 & 39 & 41.000 \\ 5 & 5 & 7 & - & 31 & 50 & 58.000 \\ 11 & 5 & 14 & 5 & 37 & 28 & 79.000 \\ & & & & & & \\ 12 & 7 & 18 & 6 & 36 & 22 & 449.000\end{array}$

\section{Nederland}

Land-, tuin- en bosbouw, visserij

Chemische industrie

Metaalindustrie en openbare nutsbedrijven

Delfstoffenwinning en aardolie industrie

Overige industrie

Bouwnijverheid en bouwinstallatiebedrijven

Groothandel en reparatiebedrijven

Detailhandel en horeca

Vervoer en communicatie

Bank- en verzekeringswezen

Overige tertiaire dienstverlening

Overheid en onderwijs

Overige kwartaire dienstverlening

Totaal

$\begin{array}{rrrrrrr}14 & 5 & 36 & 2 & 41 & 3 & 264.000 \\ 11 & 6 & 19 & 4 & 39 & 21 & 135.000 \\ 15 & 6 & 25 & 3 & 37 & 14 & 570.000 \\ - & - & - & - & 43 & 29 & 21.000 \\ 18 & 8 & 23 & 4 & 36 & 10 & 432.000 \\ 16 & 4 & 34 & 1 & 41 & 5 & 400.000 \\ 11 & 9 & 19 & 6 & 43 & 13 & 445.000 \\ 13 & 11 & 23 & 6 & 42 & 5 & 574.000 \\ 15 & 10 & 24 & 6 & 35 & 11 & 358.000 \\ 3 & 11 & 9 & 12 & 44 & 21 & 214.000 \\ 4 & 7 & 8 & 9 & 31 & 41 & 395.000 \\ 4 & 5 & 8 & 4 & 30 & 48 & 851.000 \\ 8 & 5 & 10 & 4 & 41 & 32 & 1.028 .000 \\ 10 & 7 & 18 & 5 & 38 & 22 & 5.740 .000\end{array}$
Legenda: 1 Basisonderwijs
2 MAVO en onderbouw HAVO/VWO
3 Lager Beroepsonderwijs

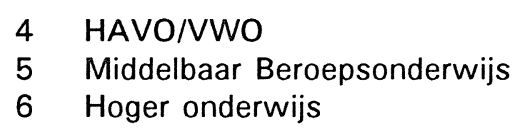

- = minder dan 3.000 werkenden 
Bij de werkenden met een opleiding op MBO-niveau zijn de grootste verschillen tussen de regio Rijnmond en de rest van Nederland waar te nemen in de bedrijfssectoren 'Delfstoffenwinning en aardolie industrie' en 'Detailhandel en horeca'. In de eerstgenoemde sector is het werkgelegenheidsaandeel van MBO-opgeleiden in de regio Rijnmond hoger dan in de rest van Nederland, terwijl in de laatstgenoemde sector het aandeel MBO-ers in Rijnmond 7\%-punt lager is dan het landelijk gemiddelde. Tevens valt op dat in de bedrijfssector 'Chemische industrie' het aantal werkenden met een MBO-opleiding in de regio Rijnmond 4\%-punt hoger ligt dan landelijk en in de sectoren 'Groothandel en reparatiebedrijven' en 'Overige kwartaire dienstverlening' 4\%punt lager. Wat betreft het aandeel hoger opgeleiden in de werkgelegenheid zijn de verschillen tussen Rijnmond en de rest van Nederland het grootst voor de bedrijfssectoren 'Overige industrie', 'Metaal industrie en openbare nutsbedrijven' en 'Overige kwartaire dienstverlening'. In de 'Overige industrie' is het aandeel hoger opgeleiden in Rijnmond 6\%-punt hoger dan het landelijke gemiddelde, terwijl in de beide andere sectoren het werkgelegenheidsaandeel van hoger opgeleiden respectievelijk $5 \%$-punt en $4 \%$-punt lager is.

Concluderend kan worden gesteld dat in de regio Rijnmond, in vergelijking met het landelijke beeld, relatief veel werkgelegenheid is voor laag geschoolden. Daarentegen zijn er in Rijnmond verhoudingsgewijs minder HAVO/VWO- en MBO-opgeleiden werkzaam. Vooral in de bedrijfssector van 'Overige kwartaire dienstverlening' is het aantal werkenden met een lagere opleiding erg hoog vergeleken met de landelijke situatie. Hier staat tegenover dat het aantal werkenden met een middelbare of hogere opleiding in deze sector relatief laag is. 


\section{DE POSITIE VAN VROUWEN EN ALLOCHTONEN OP DE ARBEIDSMARKT}

\subsection{De positie van vrouwen op de arbeidsmarkt}

Sinds de jaren '60 is de Nederlandse samenleving, qua samenstelling, zeer sterk veranderd. Zo is het aantal jongeren sterk afgenomen en is het aantal ouderen gestaag gestegen. Bedroeg de groene druk ${ }^{10}$ in 1960 nog ruim $71 \%$, in 1990 was deze reeds gedaald tot nog geen $42 \%$ (CPB, 1992). Daarentegen is de grijze druk $^{11}$ in de periode $1960-1990$ toegenomen van ongeveer $14 \%$ tot bijna $21 \%$. De verwachting is dat de grijze druk in de komende decennia nog aanzienlijk zal stijgen. Mogelijk voor een deel samenhangend met de afname van de groene druk, is het aantal vrouwen dat zich aanbiedt op de arbeidsmarkt sterk toegenomen. Dit heeft geresulteerd in meer dan een verdubbeling van de participatiegraad van vrouwen in de periode 1960-1990 (zie Ministerie van Soziale Zaken en Werkgelegenheid, 1990). Uit onderzoek van onder meer Siegers (1979), Van Mourik en Siegers (1988) en ROA (1992) is gebleken dat vrouwen in andere beroepen terechtkomen dan mannen. $\mathrm{Er}$ is sprake van een zeker segregatieeffect, waardoor kan worden gesproken van typische 'vrouwenberoepen' en typische 'vrouwenopleidingen'12. Om de aard van de werkgelegenheid voor vrouwen in de regio Rijnmond zo goed mogelijk in beeld te brengen, zal in eerste instantie worden bekeken in welke bedrijfssectoren vrouwen vooral werkzaam zijn. Daarbij zal een vergelijking worden gemaakt met het landelijke beeld. Vervolgens zal een vergelijking worden gemaakt tussen de typische 'vrouwenberoepen' en typische 'vrouwenopleidingen' in de regio Rijnmond en geheel Nederland.

\section{Sectorstructuur}

Tabel 3.1 geeft een overzicht van het aantal werkzame vrouwen per bedrijfssector in de regio Rijnmond en in geheel Nederland. Tevens is in deze tabel het aandeel van vrouwen in de totale werkgelegenheid in de desbetreffende sector weergegeven. Evenals bij het totaal aantal werkenden het geval is, is ongeveer $8 \%$ van de totale werkzame vrouwelijke beroepsbevolking in Nederland in de regio Rijnmond werkzaam. Uit de tabel blijkt dat er nauwelijks verschil bestaat tussen de sectorale werkgelegenheidsstructuur van vrouwen in de regio Rijnmond en die van geheel Nederland. De tabel laat zien dat in Rijnmond net als in geheel Nederland meer dan de helft van de vrouwelijke beroepsbevolking in de kwartaire sector werkzaam is. Wel kan worden geconcludeerd dat de in de regio Rijnmond sterk vertegenwoordigde sector 'Vervoer en communicatie' ook relatief veel werkgelegenheid biedt voor vrouwen. Tenslotte dient te worden opgemerkt dat in drie bedrijfsectoren minder dan 2.000 vrouwen werkzaam zijn. Er kan dan ook

10. Onder de groene druk wordt de bevolking van 0 tot 19 jaar verstaan als percentage van de bevolking van 20 tot 64 jaar.

11. Onder de grijze druk wordt de bevolking ouder dan 65 jaar verstaan, uitgedrukt als een percentage van de bevolking van 20 tot 64 jaar.

12. Onder typische 'vrouwenberoepen' en 'vrouwenopleidingen' verstaat Siegers (1979) die beroepen en opleidingen, waarvan meer dan $60 \%$ van de werkgelegenheid uit vrouwen bestaat. 
alleen worden geconstateerd dat in de drie sectoren tezamen ongeveer 5.000 vrouwen werkzaam zijn, hetgeen overeenkomt met ongeveer $4 \%$ van de totale werkgelegenheid voor vrouwen.

Tabel 3.1. Aantal en percentage van het totaal aantal werkende vrouwen naar bedrijfssector in de regio Rijnmond en in geheel Nederland, gemiddelde 1989-1991

Bedrijfssector

Rijnmond Nederland

aantal werkenden $\%$ aantal werkenden $\%$

Land-, tuin- en bosbouw, visserij

Chemische industrie

Metaalindustrie en openbare nutsbedrijven

Delfstoffenwinning en aardolie industrie

Overige industrie

Bouwnijverheid en bouwinstallatiebedrijven

aantal werkenden

Groothandel en reparatiebedrijven

Detailhandel en horeca

Vervoer en communicatie

Bank- en verzekeringswezen

Overige tertiaire dienstverlening

Overheid en onderwijs

Overige kwartaire dienstverlening

$\begin{array}{rrrr}- & - & 93.500 & 5 \\ - & - & 23.000 & 1 \\ 4.500 & 3 & 74.500 & 4 \\ - & - & 2.500 & 0 \\ 5.500 & 4 & 111.000 & 6 \\ 2.000 & 1 & 22.500 & 1 \\ 7.500 & 5 & 96.500 & 5 \\ 22.000 & 14 & 298.000 & 15 \\ 8.500 & 6 & 63.500 & 3 \\ 8.500 & 6 & 85.500 & 4 \\ 12.000 & 8 & 128.500 & 7 \\ 22.500 & 15 & 283.500 & 15 \\ 55.000 & 36 & 673.500 & 35 \\ 153.500 & 100 & 1.945 .500 & 100\end{array}$

Totaal

153.500

100

1.945 .500

100

- = minder dan 2.000 werkenden

Bron: CBS/ROA

In tabel 3.2 is per bedrijfssector aangegeven hoe groot het percentage vrouwen is in de werkgelegenheid in de regio Rijnmond en in geheel Nederland. De tabel laat zien dat het percentage vrouwen in de meeste bedrijfssectoren in de regio Rijnmond niet in belangrijke mate afwijkt van het landelijke beeld. In de sectoren 'Overige kwartaire dienstverlening' en 'Detailhandel en horeca' is het aandeel van vrouwen in de totale werkgelegenheid relatief groot, waarbij er overigens weinig verschil bestaat tussen Rijnmond en geheel Nederland. Wel valt op dat in de regio Rijnmond relatief veel vrouwen werkzaam zijn in de sector 'Overheid en onderwijs'. Terwijl in Nederland 33\% van deze sector uit vrouwen bestaat, bedraagt dit aandeel in de regio Rijnmond $40 \%$. Ook in de sector 'Overige industrie' is het percentage vrouwen in de regio Rijnmond verhoudingsgewijs groot. In de sector 'Vervoer en communicatie' is daarentegen het percentage vrouwen lager dan het landelijk gemiddelde. Dit betekent dat, ondanks het relatief grote belang van deze sector voor de werkgelegenheid van vrouwen in de regio Rijnmond, vrouwen niet optimaal profiteren van het grote belang van deze sector voor de werkgelegenheid in de regio Rijnmond. 
Tabel 3.2. Percentage vrouwen per bedrijfssector in de regio Rijnmond en in geheel Nederland, gemiddelde 1989-1991

Bedrijfssector

Rijnmond

Land-, tuin- en bosbouw, visserij

Chemische industrie

Metaalindustrie en openbare nutsbedrijven

Delfstoffenwinning en aardolie industrie

Overige industrie

Bouwnijverheid en bouwinstallatiebedrijven

Groothandel en reparatiebedrijven

Detailhandel en horeca

Vervoer en communicatie

Bank- en verzekeringswezen

Overige tertiaire dienstverlening

Overheid en onderwijs

Overige kwartaire dienstverlening

Totaal
$\%$

$\begin{array}{ll}- & 36 \\ - & 17\end{array}$

Nederland

$\%$

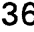

17

$13 \quad 13$

$-11$

2926

$7 \quad 6$

$21 \quad 22$

$54-53$

$15 \quad 18$

$39 \quad 41$

$32 \quad 34$

$40 \quad 33$

$69 \quad 67$

$35 \quad 34$

- $=$ minder dan 2.000 werkenden

Bron: CBS/ROA

Beroepenstructuur

Tabel 3.3 geeft aan hoe de werkgelegenheid voor vrouwen in de regio Rijnmond over de verschillende beroepssectoren is verdeeld. Daarbij zijn ook hier deze cijfers afgezet tegen de landelijke situatie. Het blijkt dat de beroepenstructuur van de werkzame vrouwen in de regio Rijnmond op slechts enkele punten afwijkt van de landelijke structuur. Vrouwen zijn in de regio Rijnmond relatief weinig werkzaam in de 'Agrarische beroepen' en de 'Technische, ambachtsen industrieberoepen', maar zijn daarentegen verhoudingsgewijs sterk vertegenwoordigd in de 'Economisch-administratieve beroepen'. Bijna de helft van alle in de regio Rijnmond werkzame vrouwen oefent een economisch-administratief beroep uit. Het verhoudingsgewijs lage aantal vrouwen in de 'Agrarische beroepen' en het relatief grote aantal vrouwen in de 'Economischadministratieve beroepen' is niet verwonderlijk gezien het lage, respectievelijk hoge totaal aantal werkenden in deze beroepssectoren in de regio Rijnmond. Het relatief kleine aantal vrouwen dat in de beroepssector 'Technische, ambachts- en industrieberoepen' werkt is wel opvallend, gezien het feit dat deze beroepssector qua grootte de tweede in de regio Rijnmond is. 
Tabel 3.3. Aantal en percentage werkende vrouwen naar beroepssector in de regio Rijnmond en geheel Nederland, gemiddelde 1989-1991

\begin{tabular}{|c|c|c|c|c|c|}
\hline $\begin{array}{l}\text { ROA- } \\
\text { code }\end{array}$ & beroepssector & $\begin{array}{l}\text { Rijnmond } \\
\text { aantal werkenden }\end{array}$ & $\%$ & $\begin{array}{l}\text { Nederland } \\
\text { aantal werkenden }\end{array}$ & $\%$ \\
\hline 0 & Pedagogische beroepen & 11.000 & 7 & 127.000 & 7 \\
\hline 1 & Culturele beroepen & & - & 30.500 & 2 \\
\hline 2 & Agrarische beroepen & 2.000 & 1 & 60.000 & 3 \\
\hline 3 & Technische, ambachts- en industrie beroepen & 7.000 & 5 & 127.000 & 7 \\
\hline 4 & Transportberoepen & 2.000 & 1 & 41.500 & 2 \\
\hline 5 & Medische en paramedische beroepen & 23.000 & 15 & 290.000 & 15 \\
\hline 6 & Economisch-administratieve beroepen & 72.000 & 47 & 845.500 & 43 \\
\hline 7 & Sociaal-culturele beroepen & 7.000 & 5 & 93.500 & 5 \\
\hline 8 & Verzorgende en dienstverlenende beroepen & 27.000 & 18 & 330.500 & 17 \\
\hline \multirow[t]{2}{*}{9} & Openbare orde- en veiligheidsberoepen & - & - & 6.000 & 0 \\
\hline & Totaal & 153.500 & 100 & 1.945 .500 & 100 \\
\hline
\end{tabular}

Bron: $\mathrm{CBS} / \mathrm{ROA}$

Tabel 3.4. Percentage vrouwen per beroepssector in de regio Rijnmond en in geheel Nederland, gemiddelde 1989-1991

$\begin{array}{lcc}\text { ROA- beroepssector } & \text { Rijnmond } & \text { Nederland } \\ \text { code } & \% & \%\end{array}$

$\begin{array}{llrl}0 & \text { Pedagogische beroepen } & 50 & 43 \\ 1 & \text { Culturele beroepen } & - & 40 \\ 2 & \text { Agrarische beroepen } & 25 & 21 \\ 3 & \text { Technische, ambachts- en industrie beroepen } & 6 & 8 \\ 4 & \text { Transportberoepen } & 6 & 13 \\ 5 & \text { Medische en paramedische beroepen } & 75 & 74 \\ 6 & \text { Economisch-administratieve beroepen } & 46 & 46 \\ 7 & \text { Sociaal-culturele beroepen } & 56 & 50 \\ 8 & \text { Verzorgende en dienstverlenende beroepen } & 69 & 69 \\ 9 & \text { Openbare orde- en veiligheidsberoepen } & - & 34 \\ & \text { Totaal } & 35 & \\ & & & \end{array}$

Bron: CBS/ROA

Het percentage vrouwen in de totale werkgelegenheid, verbijzonderd naar beroepssector, is weergegeven in tabel 3.4. Uit de tabel blijkt dat het percentage vrouwen in 'Pedagogische beroepen' in de regio Rijnmond maar liefst 7\%-punt hoger is dan landelijk het geval is. Daarentegen is ondanks het geringe aantal vrouwen dat werkzaam is in de 'Agrarische beroepen', het percentage vrouwen in deze beroepssector $4 \%$-punt hoger dan het landelijke 
cijfer. Een andere beroepssector die opvalt is de beroepssector 'Sociaal-culturele beroepen'. Het percentage vrouwen in deze beroepssector is in de regio Rijnmond 6\%-punt hoger dan het landelijke percentage. Verder is het opvallend dat het percentage vrouwen in de 'Transportberoepen' in de regio Rijnmond, in verhouding tot het landelijke cijfer, erg laag is. Terwijl landelijk gezien vrouwen $13 \%$ van de werkgelegenheid in deze beroepssector uitmaken, is dit in de regio Rijnmond slechts $6 \%$.

Uit de bovenstaande tabellen kan worden afgeleid dat er sprake is van twee duidelijke 'vrouwenberoepen', te weten 'Medische en paramedische beroepen' en 'Verzorgende en dienstverlenende beroepen'. Deze beroepssectoren zijn beide sterk gerelateerd aan de dienstensector. Als men de beroepssector 'Verzorgende en dienstverlenende beroepen' op een lager aggregatieniveau bekijkt, blijkt dat de beroepstak 'Verzorgende beroepen' er verantwoordelijk voor is dat deze sector een typische 'vrouwensector' is. Binnen deze beroepstak bestaat ongeveer $80 \%$ van de werkgelegenheid betrekking op vrouwen.

\section{Opleidingenstructuur}

Tabel 3.5 geeft een overzicht van het aantal werkzame vrouwen in de regio Rijnmond, verbijzonderd naar opleidingsniveau. Uit de tabel blijkt dat het opleidingsniveau van vrouwen in de regio Rijnmond slechts in zeer beperkte mate afwijkt van het landelijke beeld. Wel kan worden opgemerkt dat het aandeel van de lager opgeleiden (dat wil zeggen ten hoogste MAVO/LBO-niveau) in de totale werkgelegenheid voor vrouwen, evenals bij het totaal aantal werkenden (zie tabel 2.4), in Rijnmond iets hoger is dan landelijk het geval is. Het percentage vrouwen met een opleiding op MBO-niveau is daarentegen iets lager. Het bovenstaande beeld komt ook naar voren in tabel 3.6, waarin het percentage vrouwen in het totaal aantal werkenden per opleidingsniveau wordt weergegeven.

Wanneer een vergelijking wordt gemaakt met de werkgelegenheid voor mannen, verbijzonderd naar opleidingsniveau, dan valt op dat zowel in Rijnmond als in geheel Nederland, relatief veel vrouwen met 'MAVO en onderbouw HAVO/VWO' werkzaam zijn. Het verschil tussen vrouwen en mannen bedraagt respectievelijk 6\%-punt voor de regio Rijnmond en $4 \%$-punt voor geheel Nederland (zie tabel 3.5). Procentueel gezien is het aantal werkende vrouwen met een HBOopleiding aanzienlijk groter dan het aantal mannelijke arbeidskrachten. Dit geldt zowel voor de regio Rijnmond als geheel Nederland. Hier staat echter tegenover dat het percentage werkende vrouwen met een WO-opleiding aanzienlijk lager ligt dan het percentage werkende mannen op academisch niveau. Tenslotte is het aantal werkzame vrouwen met een LBO-opleiding procentueel aanzienlijk lager dan het percentage mannen met deze opleiding in zowel de regio Rijnmond als in geheel Nederland. Uit deze tabel lijkt dan ook de conclusie te kunnen worden getrokken dat vrouwen voor andere opleidingsniveaus kiezen dan mannen, zowel in de regio Rijnmond als in geheel Nederland. 
Tabel 3.5. Aantal en percentage werkende vrouwen en mannen naar opleidingsniveau in de regio Rijnmond en in geheel Nederland, gemiddelde 1990-1991

\begin{tabular}{lrrrr}
\hline Opleidingsniveau & $\begin{array}{c}\text { Rijnmond } \\
\text { aantal werkenden }\end{array}$ & $\begin{array}{l}\text { Nederland } \\
\text { aantal werkenden }\end{array}$ & $\%$ \\
\hline Vrouwen & & & \\
Basisonderwijs & & & & \\
MAVO en onderbouw HAVO/VWO & 15.000 & 10 & 174.000 & 9 \\
LBO & 17.000 & 11 & 190.000 & 10 \\
HAVO/VWO & 24.000 & 15 & 303.000 & 15 \\
MBO & 11.000 & 7 & 115.000 & 6 \\
HBO & 54.000 & 35 & 752.000 & 38 \\
WO & 30.000 & 19 & 355.000 & 18 \\
& 6.000 & 4 & 99.000 & 5 \\
Totaal & & & \\
& 156.000 & 100 & 1.994 .000 & 100 \\
Mannen & & & & \\
Basisonderwijs & & & & \\
MAVO en onderbouw & 37.000 & 13 & 423.000 & 11 \\
LBO & 15.000 & 5 & 206.000 & 6 \\
HAVO/VWO & 56.000 & 19 & 726.000 & 19 \\
MBO & 13.000 & 4 & 152.000 & 4 \\
HBO & 107.000 & 37 & 1.420 .000 & 38 \\
WO & 41.000 & 14 & 515.000 & 14 \\
& 22.000 & 8 & 291.000 & 8 \\
Totaal & & & \\
& 293.000 & 100 & 3.746 .000 & 100 \\
\hline
\end{tabular}

Bron: CBS/ROA

Tabel 3.6. Percentage vrouwen per opleidingsniveau in de regio Rijnmond en in geheel Nederland, gemiddelde 1990-1991

\begin{tabular}{lcc} 
Opleidingsniveau & $\begin{array}{c}\text { Rijnmond } \\
\%\end{array}$ & $\begin{array}{c}\text { Nederland } \\
\%\end{array}$ \\
\hline Basisonderwijs & 29 & 29 \\
MAVO en onderbouw HAVO/VWO & 53 & 48 \\
LBO & 30 & 29 \\
HAVO/VWO & 44 & 43 \\
MBO & 34 & 35 \\
HBO & 42 & 41 \\
WO & 21 & 25 \\
Totaal & 35 & 34 \\
\hline
\end{tabular}

Bron: $\mathrm{CBS} / \mathrm{ROA}$

Als men het percentage vrouwen per opleidingstype voor de regio Rijnmond en geheel Nederland met elkaar vergelijkt (zie bijlage C, tabel C.6), komen veel extremere verschillen naar voren. Het opleidingstype dat het meest opvalt is 'MBO Horeca \& Kappers'. Het aandeel van 
vrouwen in het totaal aantal werkenden met deze opleidingsachtergrond is in de regio Rijnmond maar liefst 22\%-punt hoger dan landelijk. Andere opleidingstypen die sterk van het landelijke beeld afwijken zijn: 'HBO Onderwijs', 'HBO Verpleging \& Paramedisch', 'HBO EconomischAdministratief' en 'LBO Economisch-Administratief'. In alle bovengenoemde opleidingen zijn vrouwen in de regio Rijnmond zeer sterk vertegenwoordigd. Voor 'HBO Verpleging \& Paramedisch' kan worden gesteld dat dit een typische 'vrouwenopleiding' is. De opleidingstypen 'HBO Sociaal-Cultureel' en 'HBO Onderwijs' kunnen in de regio Rijnmond bijna als een 'vrouwenopleiding' worden getypeerd. Andere typische 'vrouwenopleidingen' zijn: 'LBO Economisch-administratief', 'LBO Verzorgend', 'MBO Verpleging \& Ziekenverzorging', 'MBO Verzorgend' en 'MBO Horeca \& Kappers'. Dit beeld weerspiegelt het beeld dat in tabel 3.4 naar voren kwam van de typische 'vrouwenberoepen' Met andere woorden: de beroepensegregatie op de arbeidsmarkt vindt voor een zeer belangrijk deel al plaats bij de opleidingskeuze van mannen en vrouwen ${ }^{13}$.

\subsection{De positie van allochtonen op de arbeidsmarkt}

De andere groep die in dit hoofdstuk nader wordt belicht, betreft de allochtonen. Met het meer aantrekken van de economie in de tweede helft van de jaren tachtig, dringt breed het besef door dat deze groep structureel gezien een zeer zwakke positie op de arbeidsmarkt inneemt. De problematiek is daarbij voor een zeer groot deel geconcentreerd in de grootstedelijke gebieden (zie bijvoorbeeld Atzema en Ram, 1992). In deze paragraaf zal eerst worden aangegeven in welke sectoren allochtonen in de regio Rijnmond vooral werkzaam zijn. Daarnaast zal worden ingegaan op het opleidingsniveau van de werkzame allochtonen. Het is helaas momenteel niet goed mogelijk om een goed inzicht te krijgen in de omvang en de aard van de werkloosheidsproblematiek van allochtonen in de regio Rijnmond. Wel is duidelijk dat het werkloosheidspercentage onder allochtonen aanmerkelijk hoger is dan onder autochtonen en dat bovendien het gemiddeld scholingsniveau hierbij een grote rol speelt ${ }^{14}$.

\section{Sectorstructuur}

In de regio Rijnmond werken in totaal ongeveer 44.000 allochtonen ${ }^{15}$. Dit betekent dat deze groep $10 \%$ van de totale werkgelegenheid in de regio Rijnmond uitmaakt, hetgeen $3 \%$-punt hoger is dan het landelijke cijfer. Tabel 3.7 geeft een vergelijkend beeld van dit aantal werkzame allochtonen in de regio Rijnmond en in geheel Nederland, verbijzonderd naar bedrijfssector. Uit

13. Groot (1990) spreekt in dit verband over 'voorsortering'.

14. Het is niet mogelijk om expliciete uitspraken over de werkloosheid onder allochtonen te doen, aangezien zoals gezegd, het CBS momenteel geen gegevens over de geregistreerde werkloosheid verstrekt.

15. Het begrip allochtonen is hier in navolging aan het CBS in ruime zin gedefiniëerd, in die zin dat iedereen die niet de Nederlandse nationaliteit heeft of niet in Nederland is geboren, tot de allochtonen wordt gerekend. Ook Nederlanders die in het overzeese deel van het koninkrijk zijn geboren, worden derhalve tot de allochtonen gerekend. 
de tabel kan worden opgemaakt dat $11 \%$ van de totale in Nederland werkzame allochtone bevolking werkzaam is in de regio Rijnmond. In overeenstemming met het beeld van geheel Nederland is ook in de regio Rijnmond ongeveer een derde van de allochtonen in de kwartaire sector werkzaam. Tussen de verschillende bedrijfssectoren binnen de kwartaire sector bestaan er echter grote verschillen. In de regio Rijnmond zijn allochtonen relatief minder vaak werkzaam in de sector 'Overheid en onderwijs' en juist meer in de sector 'Overige kwartaire dienstverlening'. Een ander opvallend facet in deze tabel is het relatief geringe aantal allochtonen in de sectoren 'Metaalindustrie en openbare nutsbedrijven' en 'Overige industrie'. Hierbij dient wel te worden opgemerkt dat de totale werkgelegenheid in de beide sectoren, zoals reeds gebleken in hoofdstuk 2, in de regio Rijnmond klein is ten opzichte van de landelijke werkgelegenheid. Overeenkomstig het in hoofdstuk 2 geconstateerde beeld dat de sector 'Vervoer en communicatie' sterk in de regio Rijnmond is vertegenwoordigd, blijken ook allochtonen verhoudingsgewijs vaak in deze bedrijfssector werkzaam te zijn.

Tabel 3.7. Aantal en percentage werkende allochtonen naar bedrijfssector in de regio Rijnmond en in geheel Nederland, gemiddelde 1989-1991

\begin{tabular}{|c|c|c|c|c|}
\hline Bedrijfssector & $\begin{array}{l}\text { Rijnmond } \\
\text { aantal werkenden }\end{array}$ & $\%$ & $\begin{array}{l}\text { Nederland } \\
\text { aantal werkenden }\end{array}$ & $\%$ \\
\hline Land-, tuin- en bosbouw, visserij & - & - & 7.000 & 2 \\
\hline Chemische industrie & 2.000 & 5 & 14.000 & 4 \\
\hline Metaalindustrie en openbare nutsbedrijven & 5.000 & 11 & 56.000 & 15 \\
\hline Delfstoffenwinning en aardolie industrie & - & - & 2.500 & 1 \\
\hline Overige industrie & 3.000 & 7 & 39.000 & 10 \\
\hline Bouwnijverheid en bouwinstallatiebedrijven & 2.000 & 5 & 13.000 & 3 \\
\hline Groothandel en reparatiebedrijven & 3.000 & 7 & 24.500 & 6 \\
\hline Detailhandel en horeca & 4.500 & 10 & 40.500 & 11 \\
\hline Vervoer en communicatie & 4.000 & 9 & 22.500 & 6 \\
\hline Bank- en verzekeringswezen & 2.500 & 6 & 15.500 & 4 \\
\hline Overige tertiaire dienstverlening & 3.000 & 7 & 25.000 & 6 \\
\hline Overheid en onderwijs & 4.500 & 10 & 49.000 & 13 \\
\hline Overige kwartaire dienstverlening & 9.500 & 22 & 72.000 & 19 \\
\hline Totaal & 44.000 & 100 & 385.000 & 100 \\
\hline
\end{tabular}

Bron: CBS/ROA

Tabel 3.8 beschrijft het percentage allochtonen per bedrijfssector voor de regio Rijnmond en geheel Nederland. Zoals gezegd wordt $10 \%$ van de totale werkgelegenheid in de regio Rijnmond door allochtonen vervuld, tegenover landelijk 7\%. Daarbij kan worden opgemerkt dat voor alle onderscheiden bedrijfssectoren geldt dat het percentage allochtonen in Rijnmond groter is dan voor geheel Nederland. Het verschil is het grootst voor de sector 'Overige industrie', maar ook voor de sectoren 'Metaalindustrie en openbare nutsbedrijven' en 'Overige kwartaire dienstverlening' is het verschil aanzienlijk. Daarentegen is er een aantal sectoren waarin allochtonen relatief zwak zijn vertegenwoordigd. Dit zijn met name de sectoren 'Vervoer en communicatie' 
en 'Bouwnijverheid en bouwinstallatiebedrijven' en in mindere mate in de sectoren 'Overige tertiaire dienstverlening' en 'Overheid en onderwijs'. Overigens wijkt Rijnmond daarin niet af van het landelijke beeld.

Tabel 3.8. Percentage allochtonen per bedrijfssector in de regio Rijnmond en in geheel Nederland, gemiddelde 1989-1991

$\begin{array}{ccc}\text { Bedrijfssector } & \text { Rijnmond } & \text { Nederland } \\ \% & \%\end{array}$

Land-, tuin- en bosbouw, visserij

Chemische industrie

Metaalindustrie en openbare nutsbedrijven

Delfstoffenwinning en aardolie industrie

Overige industrie

Bouwnijverheid en bouwinstallatiebedrijven

Groothandel en reparatiebedrijven

Detailhandel en horeca

Vervoer en communicatie

Bank- en verzekeringswezen

Overige tertiaire dienstverlening

Overheid en onderwijs

Overige kwartaire dienstverlening

$\begin{array}{rr}- & 3 \\ 14 & 11 \\ 15 & 10 \\ - & 11 \\ 16 & 9 \\ 7 & 3 \\ 8 & 6 \\ 11 & 7 \\ 7 & 6 \\ 11 & 8 \\ 8 & 7 \\ 8 & 6 \\ 12 & 7 \\ 10 & \\ & \end{array}$

Totaal

11

11

9

7

6

8

7

6

7

- $=$ minder dan 2.000 werkenden

Bron: CBS/ROA

\section{Opleidingenstructuur}

Tabel 3.9 laat de verdeling zien van de werkzame allochtone beroepsbevolking naar opleidingsniveau. Ten opzichte van de landelijke situatie valt op dat er in de regio Rijnmond relatief veel allochtonen werkzaam zijn ongeschoold zijn (alleen basisonderwijs) of een LBO-opleiding hebben gevolgd. De percentages voor de regio Rijnmond liggen respectievelijk 5 en 4\%-punt hoger dan de landelijke percentages. Opvallend is verder dat in de regio Rijnmond verhoudingsgewijs veel werkzame allochtonen een opleiding op HBO-niveau hebben afgerond. Daarentegen zijn er in verhouding tot het landelijke beeld in de regio Rijnmond relatief weinig allochtonen werkzaam met een universitaire opleidingsachtergrond.

Wanneer het opleidingsniveau van werkzame allochtonen wordt gerelateerd aan het opleidingsniveau van de werkzame autochtonen in de regio Rijnmond valt vooral het zeer hoge percentage werkende allochtonen met uitsluitend basisonderwijs en het zeer lage percentage van werkende allochtonen met een MBO-opleiding op. De verschillen bedragen respectievelijk 15\%-punt meer ongeschoolde allochtonen dan autochtonen en 15\%-punt minder allochtonen met een MBOopleidingsachtergrond dan de autochtone arbeidskrachten. Het kan verder verrassend worden genoemd dat percentage allochtonen met een hogere opleiding (HBO of WO) boven dat voor de 
autochtone bevolking ligt.

Tabel 3.9. Aantal en percentage werkende allochtonen en autochtonen naar opleidingsniveau in de regio Rijnmond en in geheel Nederland, gemiddelde 1990-1991

\begin{tabular}{lrrrr} 
Opleidingsniveau & $\begin{array}{l}\text { Rijnmond } \\
\text { aantal werkenden }\end{array}$ & $\begin{array}{l}\text { Nederland } \\
\text { aantal werkenden }\end{array}$ & $\%$ \\
\hline Allochtonen & & & & \\
Basisonderwijs & & & & \\
MAVO en onderbouw HAVO/VWO & 11.000 & 25 & 84.000 & 21 \\
LBO & 3.000 & 7 & 36.000 & 9 \\
HAVO/VWO & 8.000 & 18 & 59.000 & 15 \\
MBO & 3.000 & 7 & 28.000 & 7 \\
HBO & 10.000 & 22 & 93.000 & 24 \\
WO & 7.000 & 16 & 51.000 & 13 \\
& 3.000 & 7 & 38.000 & 10 \\
Totaal & & & \\
& 43.000 & 100 & 392.000 & 100 \\
Autochtonen & & & & \\
Basisonderwijs & & & & \\
MAVO en onderbouw HAVO/VWO & & & \\
LBO & 41.000 & 10 & 513.000 & 10 \\
HAVO/VWO & 29.000 & 7 & 360.000 & 7 \\
MBO & 72.000 & 18 & 971.000 & 18 \\
HBO & 22.000 & 5 & 239.000 & 4 \\
WO & 151.000 & 37 & 2.079 .000 & 39 \\
Totaal & 64.000 & 16 & 819.000 & 15 \\
\hline
\end{tabular}

Bron: CBS/ROA

Tabel 3.10. Percentage allochtonen per opleidingsniveau in de regio Rijnmond en in geheel Nederland, gemiddelde 1990-1991

\begin{tabular}{lcc}
\hline Opleidingsniveau & $\begin{array}{c}\text { Rijnmond } \\
\%\end{array}$ & $\begin{array}{c}\text { Nederland } \\
\%\end{array}$ \\
\hline Basisonderwijs & 21 & 14 \\
MAVO en onderbouw HAVO/VWO & 9 & 9 \\
LBO & 10 & 6 \\
HAVO/VWO & 12 & 10 \\
MBO & 6 & 4 \\
HBO & 10 & 6 \\
WO & 11 & 10 \\
Totaal & 10 & 7 \\
\hline
\end{tabular}

Bron: $\mathrm{CBS} / \mathrm{ROA}$

In tabel 3.10 wordt een verbijzondering gemaakt van het percentage werkzame allochtonen 
naar opleidingsniveau. In deze tabel valt direct op dat het aandeel van de allochtonen in het aantal werkenden met uitsluitend basisonderwijs relatief hoog is. Voor de regio Rijnmond is dit beeld nog extremer dan voor de rest van Nederland. Daarentegen blijkt ook uit deze tabel dat met name van de werkende MBO-ers er relatief weinig een niet-Nederlandse achtergrond hebben. 


\section{DE ARBEIDSMARKTPOSITIE VAN SCHOOLVERLATERS}

\subsection{Inleiding}

Ook de schoolverlaters vormen een zeer specifieke groep op de arbeidsmarkt. In de eerste plaats geeft de arbeidsmarktpositie van schoolverlaters informatie over de directe aansluiting tussen het initiële onderwijs en de arbeidsmarkt. In de tweede plaats geldt voor veel mensen dat de 'uiteindelijke' positie die zij op de arbeidsmarkt bereiken voor een belangrijk deel afhankelijk is van hun arbeidsmarktsituatie direct na het verlaten van het dagonderwijs. Sinds 1992 worden op grote schaal de schoolverlaters van het AVO, het LBO en het MBO schriftelijk geënquêteerd via het onderzoek Registratie Uitstroom en Bestemming van Schoolverlaters (RUBS) (zie voor een uitgebreide rapportage Wieling, Van de Loo en Van der Velden, 1993). De enquête vindt circa driekwart jaar na het afsluiten van de dagopleiding plaats. De meest recente gegevens, die beschikbaar zijn, hebben betrekking op de schoolverlaters van het schooljaar 1990/1991, die zijn geënquêteerd in het voorjaar van 1992.

De RUBS-gegevens hebben, naast de op zich zeer waardevolle EBB-gegevens, een aantal voordelen. Het belangrijkste is dat met behulp van RUBS een beter inzicht wordt verkregen in de directe aansluiting tussen onderwijs en arbeidsmarkt. Daarmee geven de cijfers, zoals reeds werd aangegeven, ook een eerste indicatie van mogelijk te verwachten toekomstige ontwikkelingen. Daarnaast bieden de gegevens de mogelijkheid om een gedetailleerd beeld, naar opleidingscluster te geven, vanwege de minder vergaande publikatierestricties bij de RUBSgegevens in vergelijking tot de EBB. Bovendien heeft RUBS het voordeel dat hierin - in tegenstelling tot de EBB - gegevens zijn opgenomen over bijvoorbeeld de mate van onderbenutting, alsmede over de verdiende inkomens van de werkenden. Voorts is een belangrijk voordeel dat met behulp van de RUBS-gegevens kan worden voorzien in de lacune die bij de EBB bestaat met betrekking tot de werkloosheidsgegevens. Overigens zijn de RUBS-data direct koppelbaar aan de EBB-gegevens ${ }^{16}$.

In dit hoofdstuk zal op basis van de gegevens van de RUBS-enquête de arbeidsmarktpositie van de schoolverlaters in de regio Rijnmond in beeld worden gebracht. Het gaat daarbij zoals gezegd uitsluitend om de gediplomeerde schoolverlaters uit het algemeen voortgezet onderwijs, het LBO en het MBO. Daar de arbeidsmarkt voor hoger opgeleiden slechts in zeer beperkte mate regionaal is afgebakend (zie ook Windmeijer, 1992), is het overigens ook minder zinvol voor deze groep regiospecifieke informatie over het arbeidsaanbod te genereren. Evenals in de beide voorgaande hoofdstukken zal daarbij een vergelijking worden gemaakt met de landelijke situatie. Eerst wordt in paragraaf 4.2 ingegaan op de werkloosheid onder schoolverlaters. Daarna komt in paragraaf 4.3 de kwalitatieve aansluiting tussen onderwijs en arbeidsmarkt aan bod. In deze paragraaf wordt bovendien ingegaan op de inkomenspositie van de schoolverlaters. Paragraaf

16. Voor meer informatie over het gebruik van de RUBS-gegevens in combinatie met de EBB-gegevens, alsmede voor de beschrijving van enkele arbeidsmarktindicatoren op basis van de RUBS-data, wordt verwezen naar De Grip, Van der Velden en Wieling (1993). 
4.4 beschrijft vervolgens de arbeidsmarktpositie van vrouwelijke schoolverlaters, terwijl paragraaf 4.5 tenslotte ingaat op de allochtone schoolverlaters.

\subsection{Werkloosheid}

Met behulp van het werkloosheidspercentage onder schoolverlaters wordt een beeld geschetst van de directe kwantitatieve aansluiting tussen de onderscheiden opleidingen en de arbeidsmarkt. Tabel 4.1 geeft een overzicht van de werkloosheid ${ }^{17}$, verbijzonderd naar opleidingscluster, in de regio Rijnmond, waarbij een vergelijking wordt gemaakt met het werkloosheidspercentage van schoolverlaters met de desbetreffende opleidingsachtergrond voor geheel Nederland. Uit de tabel blijkt dat de totale werkloosheid onder schoolverlaters in de regio Rijnmond vrijwel niet verschilt van het totale werkloosheidspercentage voor geheel Nederland: $5 \%$.

Tabel 4.1. Werkloosheidspercentage onder schoolverlaters per opleidingscluster in de regio Rijnmond en in geheel Nederland, 1992

Opleidingscluster

Rijnmond

Nederland

werkloosheidspercentage werkloosheidspercentage

LBO agrarisch

LBO technisch

LBO economisch-administratief

LBO verzorgend

$\begin{array}{ll}0 & 3 \\ 1 & 2 \\ 4 & 7 \\ 6 & 9\end{array}$

(K)MBO agrarisch

(K)MBO technisch

(K)MBO economisch-administratief

(K)MBO verzorgend

- 2

4 3

115

MAVO

$8-5$

HAVO

$8 \quad 7$

VWO

10

Totaal

5

5

- = geen informatie i.v.m. te weinig waarnemingen

Bron: RUBS 1992/ROA

De tabel laat wel zien dat er tussen de onderscheiden opleidingsclusters enkele opmerkelijke verschillen in de ernst van de werkloosheidsproblematiek bestaan. Het meest opvallend is daarbij dat de werkloosheid onder de (gediplomeerde) schoolverlaters van het AVO in Rijnmond

17. De schoolverlaters worden als werkloos getypeerd als zij op zoek zijn naar een betaalde baan van tenminste 12 uur per week, op dit moment geen betaalde baan van 12 uur of meer per week hebben, binnen twee weken kunnen beginnen als ze een geschikte baan hebben gevonden en staan ingeschreven bij het Arbeidsbureau. Het werkloosheidspercentage wordt bepaald door het aantal werklozen te relateren aan het aantal werklozen plus het aantal werkenden, waarbij degenen die de militaire dienstplicht vervullen in het aantal werkenden worden meegerekend. 
duidelijk hoger is dan het landelijk gemiddelde voor de desbetreffende opleidingen. Dit geldt het sterkst voor de schoolverlaters van het VWO. De werkloosheid onder LBO-schoolverlaters is daarentegen in Rijnmond relatief laag in vergelijking met de landelijke cijfers. Bij de schoolverlaters van het gewoon of kort MBO is het beeld wisselend: de werkloosheid onder de schoolverlaters van het (K)MBO economisch-administratief is in Rijnmond relatief laag, terwijl daarentegen verhoudingsgewijs veel schoolverlaters van het '(K)MBO verzorgend' werkloos zijn.

Een andere manier om inzicht te krijgen in de kwantitatieve aansluiting tussen het onderwijs en de arbeidsmarkt, bestaat uit het bepalen van de zogenaamde intredewerkloosheid. Hiermee wordt een indicatie verkregen voor de snelheid waarmee schoolverlaters met succes hun intrede doen op de arbeidsmarkt. Daarbij wordt gekeken naar de totale werkloosheidsduur sinds het verlaten van de opleiding en dus niet alleen naar de duur van de werkloosheid tot de eerste baan. Hiermee wordt in belangrijke mate voorkomen dat het beeld wordt vertroebeld, i.c. te positief wordt voorgesteld, vanwege de zeer kortstondige arbeidscontracten, die juist bij jongeren nogal eens voorkomen. In tabel 4.2 is de intredewerkloosheid onder de schoolverlaters van 1990/1991 weergegeven. Ook hier is een onderscheid gemaakt naar opleidingsclusters en zijn de gegevens voor de regio Rijnmond afgezet tegen het landelijke beeld.

Tabel 4.2. Intredewerkloosheid onder schoolverlaters per opleidingscluster in de regio Rijnmond en in geheel Nederland, 1992

\begin{tabular}{|c|c|c|c|c|c|c|}
\hline \multirow[t]{2}{*}{ Opleidingscluster } & \multicolumn{3}{|c|}{$\begin{array}{c}\text { Rijnmond } \\
\text { intredewerkloosheid }\end{array}$} & \multicolumn{3}{|c|}{$\begin{array}{l}\text { Nederland } \\
\text { intredewerkloosheid }\end{array}$} \\
\hline & $\underset{\%}{0 \text { mnd }}$ & $\begin{array}{l}1-3 \text { mnd } \\
\%\end{array}$ & $\begin{array}{l}>3 \mathrm{mnd} \\
\%\end{array}$ & $\begin{array}{c}0 \text { mnd } \\
\%\end{array}$ & $\begin{array}{l}1-3 \mathrm{mnd} \\
\%\end{array}$ & $\begin{array}{l}>3 \mathrm{mnd} \\
\%\end{array}$ \\
\hline LBO agrarisch & 87 & 10 & 3 & 85 & 11 & 4 \\
\hline LBO technisch & 91 & 6 & 3 & 86 & 10 & 3 \\
\hline LBO economisch-administratief & 75 & 13 & 12 & 82 & 11 & 7 \\
\hline LBO verzorgend & 78 & 14 & 8 & 79 & 13 & 8 \\
\hline (K)MBO agrarisch & - & - & - & 86 & 9 & 5 \\
\hline (K)MBO technisch & 74 & 19 & 7 & 76 & 17 & 7 \\
\hline (K)MBO economisch-administratief & 77 & 19 & 4 & 68 & 21 & 10 \\
\hline (K)MBO verzorgend & 73 & 19 & 8 & 77 & 16 & 8 \\
\hline MAVO & 82 & 10 & 8 & 85 & 10 & 5 \\
\hline HAVO & 86 & 11 & 3 & 85 & 10 & 5 \\
\hline VWO & 80 & 17 & 2 & 88 & 9 & 3 \\
\hline Totaal & 80 & 14 & 6 & 80 & 14 & 6 \\
\hline
\end{tabular}

Bron: RUBS 1992/ROA

Ten aanzien van de intredewerkloosheid zijn er doorgaans geen of slechts geringe verschillen tussen de situatie voor de regio Rijnmond en voor geheel Nederland. Het blijkt dat MBOschoolverlaters van de onderscheiden opleidingscategorieën de meeste tijd nodig hebben voor 
het vinden van een baan. De AVO-schoolverlaters zijn doorgaans minder lang werkloos geweest. De schoolverlaters van het 'LBO technisch' hebben verhoudingsgewijs het snelst een baan gevonden.

\subsection{Kwalitatieve aansluiting onderwijs-arbeidsmarkt}

In deze paragraaf zal worden ingegaan op een tweetal kwalitatieve aspecten van de aansluiting tussen het onderwijs en de arbeidsmarkt voor schoolverlaters. Eerst wordt voor de verschillende opleidingsclusters de mate van onder- of overbenutting van het opleidingsniveau van de werkzame schoolverlaters in kaart gebracht. Vervolgens komt de inkomenspositie van de schoolverlaters aan de orde.

Tabel 4.3. Vereist opleidingsniveau (onderbenutting) van werkende schoolverlaters per opleidingscluster in de regio Rijnmond en in geheel Nederland, 1992

\begin{tabular}{|c|c|c|c|c|c|c|}
\hline \multirow[t]{2}{*}{ Opleidingscluster } & \multicolumn{3}{|c|}{$\begin{array}{c}\text { Rijnmond } \\
\text { vereist opleidingsniveau }\end{array}$} & \multicolumn{3}{|c|}{$\begin{array}{l}\text { Nederland } \\
\text { vereist opleidingsniveau }\end{array}$} \\
\hline & $\begin{array}{c}\text { lager } \\
\%\end{array}$ & $\begin{array}{l}\text { zelfde } \\
\%\end{array}$ & $\begin{array}{l}\text { hoger } \\
\%\end{array}$ & $\begin{array}{c}\text { lager } \\
\%\end{array}$ & $\begin{array}{l}\text { zelfde } \\
\%\end{array}$ & $\begin{array}{c}\text { hoger } \\
\%\end{array}$ \\
\hline LBO agrarisch & 14 & 62 & 24 & 34 & 49 & 17 \\
\hline LBO technisch & 12 & 75 & 13 & 14 & 70 & 16 \\
\hline LBO economisch-administratief & 28 & 52 & 20 & 37 & 50 & 14 \\
\hline LBO verzorgend & 24 & 64 & 12 & 36 & 51 & 13 \\
\hline (K)MBO agrarisch & - & - & - & 29 & 69 & 2 \\
\hline (K)MBO technisch & 16 & 82 & 2 & 22 & 75 & 3 \\
\hline (K)MBO economisch-administratief & 9 & 90 & 1 & 25 & 71 & 4 \\
\hline (K)MBO verzorgend & 23 & 75 & 2 & 28 & 71 & 1 \\
\hline MAVO & 27 & 66 & 7 & 42 & 47 & 11 \\
\hline HAVO & 55 & 45 & 0 & 67 & 33 & 1 \\
\hline VWO & 56 & 44 & 0 & 65 & 35 & 1 \\
\hline Totaal & 25 & 69 & 6 & 32 & 62 & 7 \\
\hline
\end{tabular}

Bron: RUBS 1992/ROA

Tabel 4.3 geeft een beeld van het vereiste opleidingsniveau, en daarmee van de mate van onderbenutting ${ }^{18}$ van de werkende schoolverlaters, verbijzonderd naar opleidingscluster. Uit de tabel kan worden opgemaakt dat in de regio Rijnmond verhoudingsgewijs minder schoolverlaters in hun kwalificaties worden onderbenut dan in de rest van Nederland. Dit geldt opvallend genoeg voor alle onderscheiden opleidingsclusters. Bij het '(K)MBO economisch-administratief'

18. Overigens moet daarbij worden bedacht dat het hier doorgaans startfuncties betreft, waarbij een verdere doorgroei naar een wel aansluitend functieniveau tot de mogelijkheden behoort (zie ook De Grip, Heijke en Willems, 1992). 
is het verschil het meest opmerkelijk: terwijl op landelijk niveau ongeveer een kwart van de schoolverlaters werkzaam is in een functie, waarvoor slechts een lager opleidingsniveau vereist is dan waarover de desbetreffende schoolverlater beschikt, is dit in de regio Rijnmond nog geen $10 \%$. In de vorige paragraaf is reeds gebleken dat het werkloosheidspercentage voor deze opleidingscategorie in Rijnmond relatief laag is, zodat kan worden vastgesteld dat de huidige arbeidsmarktpositie voor deze schoolverlaters in de regio in verhouding tot het landelijke beeld erg gunstig is. Andere opleidingsclusters waar de mate van onderbenutting in Rijnmond in vergelijking met het landelijke beeld voor de desbetreffende opleiding opvallend laag is, zijn het 'LBO agrarisch' en het 'MAVO'.

Vervolgens wordt ingegaan op het inkomen dat door de schoolverlaters wordt verdiend. In de RUBS-enquête betreft dit het netto inkomen per maand, inclusief eventuele fooien of toeslagen, maar exclusief overwerk of vakantiegeld. Er is voor gekozen om geen omrekening te maken naar de verdiende uurlonen, mede omdat de verschillen tussen de opleidingsclusters wellicht meer voortvloeien uit verschillen in de beschikbaarheid van voltijdsbanen voor schoolverlaters binnen een bepaalde opleidingscluster dan uit verschillen tussen deze schoolverlaters wat betreft het gewenste aantal te werken uren.

Tabel 4.4. Gemiddeld netto maandloon van werkende schoolverlaters per opleidingscluster in de regio Rijnmond en in geheel Nederland, 1992

Opleidingscluster

Rijnmond gem. netto mndloon
Nederland

gem. netto mndloon

\begin{tabular}{|c|c|c|c|}
\hline LBO agrarisch & 800 & $\mathrm{fl}$ & 832 \\
\hline LBO technisch & 811 & $\mathrm{fl}$ & 860 \\
\hline LBO economisch-administratief & 725 & $\mathrm{fl}$ & 731 \\
\hline LBO verzorgend & 711 & $\mathrm{fl}$ & 731 \\
\hline (K)MBO agrarisch & - & $\mathrm{fl}$ & 1.352 \\
\hline (K)MBO technisch & $\mathrm{fl} 1.820$ & $\mathrm{fl}$ & 1.617 \\
\hline (K)MBO economisch-administratief & $\mathrm{fl} 1.559$ & $\mathrm{fl}$ & 1.361 \\
\hline (K)MBO verzorgend & $\mathrm{fl} 1.505$ & $\mathrm{fl}$ & 1.365 \\
\hline MAVO & 710 & $\mathrm{fl}$ & 670 \\
\hline HAVO & 873 & $\mathrm{fl}$ & 870 \\
\hline VWO & 876 & $\mathrm{fl}$ & 856 \\
\hline Totaal & fl 1.118 & $\mathrm{fl}$ & 1.105 \\
\hline
\end{tabular}

Bron: RUBS 1992/ROA

Uit de in tabel 4.4 gepresenteerde gegevens blijkt dat de schoolverlaters in de regio Rijnmond gemiddeld net iets meer verdienen dan in de rest van het land. Vooral MBO-schoolverlaters hebben op dit punt in de regio een erg gunstige positie met gemiddelde netto maandinkomens die maar liefst $\mathrm{fl} 150,--$ tot $\mathrm{fl} 200,--$ boven het landelijke gemiddelde voor de desbetreffende 
opleidingscategorie liggen. Opvallend is dat de LBO-schoolverlaters daarentegen in Rijnmond een iets lager loon verdienen dan hun collega's elders in het land. De verschillen zijn, met uitzondering van de schoolverlaters met een opleiding LBO-technisch, echter gering. Dit laatste geldt ook voor de schoolverlaters van het AVO, maar dan in het voordeel van degenen die in de regio Rijnmond werken.

Samenvattend kan worden gesteld dat de arbeidsmarktpositie van de schoolverlaters in het algemeen iets gunstiger is ten opzichte van het landelijke beeld. De werkloosheid is weliswaar min of meer gelijk, maar in de regio Rijnmond worden minder schoolverlaters in hun kwalificaties onderbenut in vergelijking met de rest van Nederland, terwijl zij bovendien gemiddeld een iets hoger inkomen verdienen. Daarbij zijn er overigens wel redelijke verschillen tussen de onderscheiden opleidingscategorieën. Een in verhouding tot de rest van Nederland opvallend gunstige arbeidsmarktpositie wordt waargenomen onder de schoolverlaters van het opleidingscluster '(K)MBO economisch-administratief': de werkloosheid onder deze groep schoolverlaters is erg laag, de mate van onderbenutting is vrij gering en bovendien verdienen zij gemiddeld circa fl 200,-- netto per maand meer dan de schoolverlaters van deze opleiding die in de rest van Nederland werken. Mogelijk hangt dit samen met de sterke vertegenwoordiging van de beroepssector 'Economisch-administratieve beroepen', zoals die in hoofdstuk 2 is geconstateerd. De schoolverlaters van het LBO technisch onderscheiden zich qua verdiensten in ongunstige zin in vergelijking met het landelijke beeld.

\subsection{De arbeidsmarktpositie van vrouwelijke schoolverlaters}

Nadat in hoofdstuk 3 is ingegaan op de arbeidsmarktpositie van vrouwen in het algemeen, wordt in deze paragraaf specifiek aandacht besteed aan de situatie van vrouwelijke schoolverlaters op de arbeidsmarkt. Daarbij zal op dezelfde indicatoren worden ingegaan als in de beide voorgaande paragrafen. De resultaten op basis van de RUBS-enquête zijn weergegeven in tabel 4.5 .

De tabel laat zien dat de werkloosheid onder vrouwelijke schoolverlaters twee keer zo hoog is als die onder hun mannelijke collega's. Op dit punt is er niet of nauwelijks verschil tussen het landelijke beeld en de situatie in de regio Rijnmond. Ook ten aanzien van de duur van de intredewerkloosheid van schoolverlaters bestaan er geen grote verschillen tussen Rijnmond en de rest van Nederland. De arbeidsmarktpositie van vrouwen is op dit punt in beide gevallen iets minder gunstig dan de positie van mannelijke schoolverlaters op de arbeidsmarkt.

In paragraaf 4.3 is reeds geconstateerd dat in de regio Rijnmond in vergelijking met de rest van Nederland relatief weinig arbeidskrachten in hun kwalificaties worden onderbenut. Uit tabel 4.5 blijkt dat dit voor zowel vrouwen als mannen geldt. Het verschil tussen mannen en vrouwen in de regio Rijnmond is, wat betreft onderbenutting, klein. Opvallend is het verschil in netto inkomen tussen mannelijke en vrouwelijke schoolverlaters in de regio Rijnmond. De mannen die in de regio Rijnmond werken verdienen iets minder dan in de rest van het land. De vrouwelijke schoolverlaters in de regio Rijnmond hebben daarentegen een hoger maandinkomen dan de 
vrouwelijke schoolverlaters in de rest van Nederland. Bovendien is dit maandinkomen gemiddeld hoger dan het inkomen van de mannelijke schoolverlaters in de regio. Dit hangt echter nauw samen met het feit dat de vrouwelijke schoolverlaters relatief vaker een MBO-opleiding hebben afgesloten, terwijl de mannen vaker met een LBO-opleiding op de arbeidsmarkt terecht komen.

Tabel 4.5. De positie van vrouwelijke en mannelijke schoolverlaters op de arbeidsmarkt in de regio Rijnmond en in geheel Nederland, 1992

\begin{tabular}{|c|c|c|c|c|}
\hline \multirow[t]{2}{*}{ Indicator } & \multicolumn{2}{|c|}{ Rijnmond } & \multicolumn{2}{|c|}{ Nederland } \\
\hline & $\begin{array}{c}\text { mannen } \\
\%\end{array}$ & $\begin{array}{c}\text { vrouwen } \\
\%\end{array}$ & $\underset{\%}{\operatorname{mannen}}$ & $\begin{array}{c}\text { vrouwen } \\
\%\end{array}$ \\
\hline Werkloosheidspercentage & 3 & 6 & 3 & 6 \\
\hline \multicolumn{5}{|l|}{ Intredewerkloosheid: } \\
\hline $0 \mathrm{mnd}$ & 87 & 76 & 84 & 76 \\
\hline $1-3 \mathrm{mnd}$ & 9 & 17 & 11 & 16 \\
\hline$>3 \mathrm{mnd}$ & 3 & 7 & 5 & 8 \\
\hline \multicolumn{5}{|l|}{ Vereist opleidingsniveau: } \\
\hline lager & 24 & 26 & 30 & 33 \\
\hline zelfde & 69 & 69 & 61 & 62 \\
\hline hoger & 7 & 5 & 9 & 5 \\
\hline Gem. netto maandloon & fl 1.087 & fl 1.140 & fl 1.094 & fl 1.113 \\
\hline
\end{tabular}

Bron: RUBS 1992/ROA

\subsection{De arbeidsmarktpositie van allochtone schoolverlaters}

Ook de positie van de allochtone ${ }^{19}$ schoolverlaters op de arbeidsmarkt kan aan de hand van enkele indicatoren nader worden belicht. De allochtone schoolverlaters hebben een veel slechtere arbeidsmarktpositie dan hun autochtone collega's. Dit geldt zowel voor Nederland als geheel, als voor de regio Rijnmond. Bovendien blijkt zowel de kwantitatieve als de kwalitatieve aansluiting tussen het onderwijs en de arbeidsmarkt voor allochtone schoolverlaters relatief slechter te zijn. Tabel 4.6 geeft hiervan een overzicht.

De werkloosheid onder allochtone schoolverlaters is in het algemeen veel hoger dan onder autochtone schoolverlaters. Voor Rijnmond is de situatie weliswaar iets gunstiger dan landelijk, maar ook hier geldt dat allochtonen veel vaker werkloos zijn. Uit de tabel blijkt ook dat voor allochtonen het intredeproces op de arbeidsmarkt veel minder soepel verloopt, getuige de gemiddeld langere duur van de intredewerkloosheid. Op dit punt wijkt de regio Rijnmond nauwelijks af van Nederland als geheel.

19. In de RUBS-enquête wordt - in tegenstelling tot de EBB - direct gevraagd naar de etniciteit van de respondenten. De schoolverlaters worden tot de allochtonen gerekend indien zij aangeven niet tot de Nederlandse etniciteit te behoren. 
Zoals gezegd, is ook de kwalitatieve aansluiting tussen het gevolgde onderwijs en de positie op de arbeidsmarkt voor allochtone schoolverlaters slechter dan voor hun autochtone collega's. De verschillen in de mate van onderbenutting zijn daarbij in de regio Rijnmond duidelijk groter dan in de rest van Nederland. Het verschil kan vooral worden toegeschreven aan de relatief gunstige positie van de autochtone schoolverlaters in de regio, terwijl de mate van onderbenutting van allochtonen in de regio Rijnmond nauwelijks verschilt van het landelijke beeld. De verschillen in de kwalitatieve arbeidsmarktsituatie tussen autochtonen en allochtonen zijn het meest duidelijk zichtbaar in de inkomensverschillen tussen beide groepen. In Rijnmond is het verschil daarbij nog aanmerkelijk groter dan in de rest van Nederland.

Tabel 4.6. De positie van allochtone en autochtone schoolverlaters op de arbeidsmarkt in de regio Rijnmond en in geheel Nederland, 1992

\begin{tabular}{|c|c|c|c|c|}
\hline \multirow[t]{2}{*}{ Indicator } & \multicolumn{2}{|c|}{ Rijnmond } & \multicolumn{2}{|c|}{ Nederland } \\
\hline & autochtonen & allochtonen & autochtone & allochtone \\
\hline Werkloosheidspercentage & 5 & 12 & 4 & 15 \\
\hline \multicolumn{5}{|l|}{ Intredewerkloosheid: } \\
\hline $0 \mathrm{mnd}$ & 81 & 67 & 80 & 64 \\
\hline $1-3 \mathrm{mnd}$ & 14 & 13 & 14 & 18 \\
\hline$>3 \mathrm{mnd}$ & 5 & 20 & 6 & 18 \\
\hline \multicolumn{5}{|l|}{ Vereist opleidingsniveau: } \\
\hline lager & 25 & 38 & 31 & 41 \\
\hline zelfde & 69 & 57 & 62 & 50 \\
\hline hoger & 6 & 5 & 7 & 9 \\
\hline Gem. netto maandloon & fl 1.123 & fl 985 & fl 1.105 & fl 1.063 \\
\hline
\end{tabular}

Bron: RUBS 1992/ROA 


\section{FORENSENSTROMEN}

\subsection{Inleiding}

Dit hoofdstuk probeert inzicht te geven in de forensenstromen van en naar de regio Rijnmond. Dit is onder meer van belang, omdat forensenstromen in het algemeen een beeld geven van de verhouding van vraag en aanbod op de regionale arbeidsmarkt. Een grote forensenstroom duidt op een in vergelijking met andere regio's grote spanning tussen de vraag naar en het aanbod van werk in de regio. Een kleine forensenstroom, daarentegen, geeft een goede match aan tussen de vraag naar arbeidskrachten en het aanbod van de in de regio woonachtige beroepsbevolking ${ }^{20}$.

Daarnaast heeft de opleidingenstructuur van de in de regio woonachtige werkzame beroepsbevolking invloed op de aantrekkelijkheid van de regio als vestigingsplaats voor bedrijven en andere instellingen. Wonen er in een regio bijvoorbeeld relatief veel hoog geschoolden met een technische achtergrond, dan zal de regio aantrekkelijk zijn voor high-tech- en maatwerkbedrijven. Voor een eventueel te voeren regionaal ontwikkelingsbeleid, dat er op is gericht de werkgelegenheid voor de in de regio woonachtige beroepsbevolking te vergroten, is het derhalve niet voldoende alleen naar de huidige structuur van de regionale werkgelegenheid te kijken, maar moet tevens worden nagegaan welk deel van de arbeidsplaatsen wordt vervuld door pendelaars.

Tabel 5.1. Aantallen werkenden naar woonregio en werkregio, gemiddelde 1990-1991

\begin{tabular}{lrrr}
\hline Woonregio & Rijnmond & $\begin{array}{l}\text { werkregio } \\
\text { rest Nederland }\end{array}$ & totaal \\
\hline Rijnmond & 343.000 & 73.000 & 416.000 \\
Rest Nederland & 106.000 & 5.218 .000 & 5.325 .000 \\
Totaal & 449.000 & 5.291 .000 & 5.740 .000 \\
\hline
\end{tabular}

Bron: CBS/ROA

In tabel 5.1 wordt een overzicht gegeven van de totale omvang van de forensenstromen tussen Rijnmond en Nederland. Het in- en uitgaande pendelverkeer in de regio Rijnmond bedraagt in totaal 179.000 personen: 106.000 werkenden in de regio Rijnmond wonen buiten de regio, terwijl 73.000 mensen die in de regio Rijnmond wonen elders werkzaam zijn. Per saldo is er derhalve sprake van een netto ingaande pendel van 33.000 personen. Dit betekent dat de totale forensenstroom in verhouding tot het saldo van in- en uitgaande pendel bijzonder groot is.

20. Vanzelfsprekend moet daarbij ook rekening worden gehouden met het feit dat forensenstromen ook in belangrijke mate bepaald kunnen worden door de ruimtelijke onderwijsproblematiek. 
Mogelijk hangt dit samen met verschillen in de kwalitatieve structuur van de werkgelegenheid en van de beroepsbevolking in de regio Rijnmond. In paragraaf 5.2. wordt daarom ingegaan op de verbijzondering van de pendelstromen naar bedrijfssector. In paragraaf 5.3. komt vervolgens de omvang van de pendel naar opleidingsniveau aan bod.

\subsection{Forensenstromen per bedrijfssector}

In deze paragraaf zal worden nagegaan op welke bedrijfssectoren de pendel vooral betrekking heeft. Tabel 5.2 geeft een beeld van de omvang van zowel de ingaande als de uitgaande pendel, verbijzonderd naar de verschillende bedrijfssectoren. Daarbij is tevens het aandeel van de ingaande pendel in de werkgelegenheid in de regio Rijnmond weergegeven en is de uitgaande pendel gerelateerd aan het totaal aantal in de regio Rijnmond wonende arbeidskrachten. Zoals ook al uit tabel 5.1 kon worden afgeleid, blijkt maar liefst bijna een kwart van de werkenden in de regio Rijnmond buiten de regio werkzaam te zijn, terwijl $18 \%$ van degenen die in Rijnmond wonen elders werkzaam is. Uit de tabel blijkt dat voor vrijwel alle bedrijfssectoren de ingaande pendel groter is dan de uitgaande. Alleen de sectoren 'Metaalindustrie en openbare nutsbedrijven' en 'Land-, tuin- en bosbouw, visserij' vormen hierop een uitzondering.

Tabel 5.2. In- en uitgaande forensenstromen naar bedrijfssector voor de regio Rijnmond, gemiddelde 1989-1991

\begin{tabular}{|c|c|c|c|c|}
\hline Bedrijfssector & $\begin{array}{l}\text { ingaande pendel } \\
\text { aantal }\end{array}$ & $\%^{*}$ & $\begin{array}{l}\text { uitgaande pendel } \\
\text { aantal }\end{array}$ & $\%{ }^{* *}$ \\
\hline Land-, tuin- en bosbouw, visserij & - & - & 2.500 & 28 \\
\hline Chemische industrie & 2.500 & 18 & - & - \\
\hline Metaalindustrie en openbare nutsbedrijven & 6.500 & 19 & 8.000 & 23 \\
\hline Delfstoffenwinning en aardolie industrie & 2.500 & 36 & - & - \\
\hline Overige industrie & 5.000 & 26 & 4.500 & 24 \\
\hline Bouwnijverheid en bouwinstallatiebedrijven & 10.000 & 33 & 5.500 & 22 \\
\hline Groothandel en reparatiebedrijven & 9.500 & 26 & 8.000 & 23 \\
\hline Detailhandel en horeca & 6.000 & 15 & 4.000 & 10 \\
\hline Vervoer en communicatie & 15.500 & 28 & 4.500 & 10 \\
\hline Bank- en verzekeringswezen & 7.000 & 32 & 3.000 & 17 \\
\hline Overige tertiaire dienstverlening & 12.000 & 32 & 8.000 & 24 \\
\hline Overheid en onderwijs & 15.000 & 27 & 13.500 & 25 \\
\hline Overige kwartaire dienstverlening & 14.500 & 18 & 8.000 & 11 \\
\hline Totaal & 107.000 & 24 & 72.500 & 18 \\
\hline $\begin{array}{l}\text { - minder dan } 2.000 \text { werkenden } \\
\text { als percentage van de in de regio Rijnmc } \\
\text { als percentage van de in de regio Rijnmc }\end{array}$ & $\begin{array}{l}\text { rkzame beroepsb } \\
\text { onachtige werkz }\end{array}$ & $\mathrm{ng}$ & evolking & \\
\hline
\end{tabular}

Bron: $\mathrm{CBS} / \mathrm{ROA}$

Zeer opvallend is dat zowel de ingaande als de uitgaande pendel in de regio Rijnmond voor meer dan $80 \%$ betrekking heeft op de tertiaire en kwartaire sector. De sector 'Vervoer en communicatie' springt er uit, omdat de ingaande forensenstroom in deze sector aanzienlijk groter is dan 
de uitgaande forensenstroom. Dit is niet geheel verwonderlijk, aangezien in hoofdstuk 2 reeds is gebleken dat deze sector zeer sterk in de regio Rijnmond is vertegenwoordigd. Ook in de sector 'Bank- en verzekeringswezen' en de 'Bouwnijverheid en bouwinstallatiebedrijven' is er sprake van een veel grotere grote ingaande dan uitgaande pendel. Voor de sector 'Overheid en onderwijs' is de totale pendel in absolute zin het grootst. Daarbij is het opvallend dat de ingaande en uitgaande forensenstromen van deze sector elkaar bijna opheffen. Wanneer men de relatieve forensenstromen in de regio Rijnmond bekijkt zijn er enkele sectoren die sterk opvallen. De ingaande pendel is verhoudingsgewijs het grootst in de sector 'Delfstoffenwinning en aardolie industrie', die zoals gezegd sterk in de regio is vertegenwoordigd. Verder valt op dat er verschillende sectoren in de regio Rijnmond zijn die voor ongeveer een derde deel afhankelijk zijn van ingaande forensenstromen. Dit betreft de sectoren 'Bouwnijverheid en bouwinstallatiebedrijven', 'Bank- en verzekeringswezen' en 'Overige tertiaire dienstverlening'. Bij zowel de eerste als de laatstgenoemde sector is het opvallend dat ook de uitgaande pendel relatief hoog is.

\subsection{Forensenstromen per opleidingsniveau}

In tabel 5.3 wordt een overzicht gegeven van de in- en uitgaande forensenstromen, verbijzonderd naar opleidingsniveau in de regio Rijnmond. Tevens is aangegeven hoe deze pendelstromen zich verhouden tot het aantal werkenden die in de regio Rijnmond werken, respectievelijk wonen.

Tabel 5.3. In- en uitgaande forensenstromen naar opleidingsniveau voor de regio Rijnmond, gemiddelde 1990-1991

\begin{tabular}{|c|c|c|c|c|}
\hline Opleidingsniveau & $\begin{array}{l}\text { ingaande pendel } \\
\text { aantal }\end{array}$ & $\%{ }^{*}$ & $\begin{array}{l}\text { uitgaande pendel } \\
\text { aantal }\end{array}$ & $\%{ }^{* *}$ \\
\hline Basisonderwijs & 7.000 & 13 & 6.000 & 12 \\
\hline MAVO en onderbouw HAVO/VWO & 7.000 & 22 & 4.000 & 14 \\
\hline LBO & 14.000 & 18 & 12.000 & 15 \\
\hline HAVO/VWO & 5.000 & 21 & 4.000 & 17 \\
\hline $\mathrm{MBO}$ & 38.000 & 24 & 26.000 & 18 \\
\hline $\mathrm{HBO}$ & 24.000 & 34 & 12.000 & 20 \\
\hline WO & 13.000 & 46 & 8.000 & 35 \\
\hline Totaal & 106.000 & 24 & 73.000 & 18 \\
\hline
\end{tabular}

Bron: CBS/ROA

De tabel laat ook zien dat meer dan 35\% van het forensisme betrekking heeft op MBOopgeleiden. Gezien de opleidingenstructuur van de beroepsbevolking is het echter niet verwonderlijk dat deze groep het grootste aantal pendelaars heeft. Tevens kan uit tabel 5.3 
worden afgeleid dat ongeveer $30 \%$ van de totale uitgaande pendel bestaat uit werkenden met een opleiding op MAVO/LBO-niveau of lager. Daarentegen is deze groep slechts verantwoordelijk voor circa $20 \%$ van de totale ingaande pendel. Van de totale uitgaande pendel heeft bijna $30 \%$ een opleiding op HBO- of WO-niveau. Van de totale ingaande pendel in de regio Rijnmond maken de hoger opgeleiden $35 \%$ uit. In het algemeen kan worden opgemerkt dat weliswaar op alle opleidingsniveaus de ingaande pendel in absolute zin groter is dan de uitgaande pendel. Maar bij de hogere opleidingsniveaus is het verschil veel groter dan bij de lager opleidingsniveaus.

Wanneer men de relatieve pendelstromen naar opleidingsniveau bekijkt, dan valt op dat er vooral op HBO- en WO-niveau sprake is van een relatief groot aantal ingaande forensen. Zo blijkt dat maar liefst $46 \%$ van de in de regio Rijnmond werkzame academici buiten de regio woont. Bij de HBO-ers is dit circa $35 \%$. Van de arbeidskrachten op WO- en HBO-niveau die in de regio Rijnmond wonen, is respectievelijk $35 \%$ en $20 \%$ buiten de regio werkzaam. Het percentage pendelaars op de lagere niveaus is, zowel ingaand als uitgaand, beduidend lager. Dit geldt het sterkst voor de ongeschoolden. Zo wordt slechts $13 \%$ van de werkgelegenheid voor ongeschoolden in de regio Rijnmond opgevuld door arbeidskrachten die afkomstig zijn van buiten de regio. 


\section{ROTTERDAM NADER BELICHT}

\subsection{Inleiding}

In Nederland staan de grote steden er om bekend verzamelbekkens te zijn van laag opgeleiden, terwijl er juist veel werkgelegenheid is voor hoger opgeleiden. Deze vraag moet dan worden opgevuld door buiten de stad wonende hoger opgeleiden. In dit hoofdstuk zal de positie op de arbeidsmarkt van de stad Rotterdam vanuit enkele gezichtsvelden nader worden belicht.

De opbouw van dit hoofdstuk is als volgt. Eerst zal in paragraaf 6.2. worden ingegaan op de opleidingenstructuur. Daarbij komt niet alleen de opleidingenstructuur van diegenen die in de stad werken aan bod, maar wordt tevens ingegaan op degenen die in de stad Rotterdam woonachtig zijn. Vervolgens wordt in paragraaf 6.3. een overzicht gegeven van de in- en uitgaande pendelstromen van Rotterdam naar de rest van de regio Rijnmond en de rest van Nederland.

\subsection{Opleidingsniveau in Rotterdam}

Tabel 6.1 beschrijft het opleidingsniveau van de werkgelegenheid in Rotterdam. Het blijkt dat de werkgelegenheidsstructuur op dit punt in Rotterdam nauwelijks afwijkt van de rest van de regio Rijnmond. Dit is echter niet vreemd, daar maar liefst tweederde van de totale werkgelegenheid van Rijnmond in de stad Rotterdam is geconcentreerd. De tabel laat verder zien dat in Rotterdam relatief iets meer HBO- en WO-opgeleiden werken dan in de rest van Rijnmond. Het aandeel van LBO- en MBO-opgeleiden in de totale stedelijke werkgelegenheid is daarentegen iets kleiner.

Tabel 6.1. Aantal en percentage werkenden naar opleidingsniveau werkzaam in Rotterdam en in geheel Rijnmond, gemiddelde 1990-1991

\begin{tabular}{lrrrr}
\hline Opleidingsniveau & $\begin{array}{l}\text { Rotterdam } \\
\text { aantal werkenden }\end{array}$ & $\begin{array}{c}\text { geheel Rijnmond } \\
\text { aantal werkenden }\end{array}$ \\
\hline Basisonderwijs & 36.000 & 12 & 52.000 & 12 \\
MAVO en onderbouw HAVO/VWO & 21.000 & 7 & 32.000 & 7 \\
LBO & 48.000 & 16 & 80.000 & 18 \\
HAVO/VWO & 18.000 & 6 & 24.000 & 5 \\
MBO & 104.000 & 34 & 160.000 & 36 \\
HBO & 51.000 & 17 & 70.000 & 16 \\
WO & 23.000 & 8 & 28.000 & 6 \\
Totaal & 302.000 & 100 & 449.000 & 100 \\
\hline
\end{tabular}

Bron: CBS/ROA

Tabel 6.2 geeft vervolgens een beeld van de in Rotterdam woonachtige werkzame beroepsbevolking, verbijzonderd naar opleidingsniveau. Het valt op dat, zoals in de inleiding van dit 
hoofdstuk al werd verondersteld, in Rotterdam verhoudingsgewijs veel (werkende) lager opgeleiden wonen. Zo ligt het percentage ongeschoolden in Rotterdam aanzienlijk boven het percentage voor geheel Rijnmond. Het percentage hoger opgeleiden in Rotterdam ligt echter eveneens iets hoger dan het percentage voor geheel Rijnmond. Waarschijnlijk hangt dit laatste samen met de aantrekkelijkheid van de grootstedelijke woonomgeving van bepaalde groepen hoger opgeleiden. Opmerkelijk is het lage percentage werkenden met een opleiding op MBOniveau dat woonachtig is in Rotterdam. Het percentage voor Rotterdam is maar liefst 6\%-punt lager dan het percentage voor geheel Rijnmond. Het is met name deze middengroep waarvoor de grootstedelijke woonomgeving weinig aantrekkelijk lijkt te zijn.

Tabel 6.2. Aantal en percentage werkenden naar opleidingsniveau wonend in Rotterdam en in geheel Rijnmond, gemiddelde 1990-1991

\begin{tabular}{lrrrr} 
Opleidingsniveau & $\begin{array}{l}\text { Rotterdam } \\
\text { aantal werkenden }\end{array}$ & $\begin{array}{l}\text { geheel Rijnmond } \\
\text { aantal werkenden }\end{array}$ \\
\hline Basisonderwijs & 30.000 & 15 & 50.000 & 12 \\
MAVO en onderbouw HAVO/VWO & 14.000 & 7 & 30.000 & 7 \\
LBO & 37.000 & 19 & 78.000 & 19 \\
HAVO/VWO & 14.000 & 7 & 24.000 & 6 \\
MBO & 59.000 & 30 & 148.000 & 36 \\
HBO & 28.000 & 14 & 59.000 & 14 \\
WO & 15.000 & 8 & 23.000 & 6 \\
Totaal & 198.000 & 100 & 415.000 & 100 \\
\hline
\end{tabular}

Bron: $\mathrm{CBS} / \mathrm{ROA}$

\subsection{Forensenstromen}

In deze paragraaf wordt de omvang van de forensenstromen tussen de stad Rotterdam, de rest van de regio Rijnmond en de rest van Nederland in beeld gebracht. Daarvoor wordt eerst in tabel 6.3 een overzicht gegeven van het totaal aantal werkenden in Rotterdam, de rest van Rijnmond en de rest van Nederland, verbijzonderd naar woonregio. Het valt op dat meer dan de helft van de in Rotterdam werkzame beroepsbevolking van buiten de stad komt, waarvan de helft zelfs van buiten de regio Rijnmond komt. Verder is het opvallend dat meer dan $25 \%$ van de in Rotterdam woonachtige (werkzame) beroepsbevolking buiten Rotterdam werkt. Dit duidt er op dat in Rotterdam de vraag naar en het aanbod van arbeid wellicht onvoldoende op elkaar aansluiten. Om een beeld te krijgen van de achterliggende structuur van deze 'structurele' spanning op de Rotterdamse arbeidsmarkt, zal de pendel van en naar Rotterdam worden bekeken. Eerst zal worden nagegaan waar de in Rotterdam woonachtige werkzame beroepsbevolking werkzaam is. Vervolgens zal worden ingegaan op de vraag naar arbeid in Rotterdam en waar de benodigde arbeidskrachten vandaan komen. 
Tabel 6.3. Aantal werkenden naar woonplaats en werkregio, gemiddelde 1990-1991

\begin{tabular}{lrrrr}
\hline Woonregio & Rotterdam & $\begin{array}{l}\text { werkregio } \\
\text { rest Rijnmond }\end{array}$ & rest Nederland & totaal \\
\hline Rotterdam & 147.000 & 18.000 & 33.000 & 198.000 \\
Rest Rijnmond & 76.000 & 102.000 & 40.000 & 217.000 \\
Rest Nederland & 79.000 & 27.000 & 5.218 .000 & 5.740 .000 \\
Totaal & 302.000 & 147.000 & 5.291 .000 & 5.740 .000 \\
\hline
\end{tabular}

Bron: ROA/CBS

In tabel 6.4 is aangegeven waar de in Rotterdam wonende arbeidskrachten, verbijzonderd naar opleidingsniveau, werkzaam zijn. Zoals al eerder vermeld, werkt ongeveer een kwart van de in Rotterdam woonachtige werkenden buiten de stad. Vooral het percentage academici dat buiten Rotterdam werkt is relatief groot, namelijk $40 \%$. Opvallend is dat deze academici bijna allemaal buiten de regio Rijnmond werken. Van alle andere opleidingsniveaus werkt ongeveer een kwart buiten Rotterdam, hetgeen ongeveer overeenkomt met het totale percentage.

Tabel 6.4. Overzicht van de in Rotterdam wonende werkzame beroepsbevolking naar opleidingsniveau en werkregio, gemiddelde 1990-1991

\begin{tabular}{lrcrr}
\hline Opleidingsniveau & $\begin{array}{l}\text { werkzaam in } \\
\text { Rotterdam }\end{array}$ & $\begin{array}{l}\text { werkzaam in } \\
\text { overig Rijnmond }\end{array}$ & $\begin{array}{l}\text { werkzaam in } \\
\text { overig Nederland }\end{array}$ & totaal \\
\hline Basisonderwijs & 25.000 & 3.000 & 3.000 & 30.000 \\
MAVO en onderbouw HAVO/VWO & 11.000 & - & - & 14.000 \\
LBO & 28.000 & 4.000 & 5.000 & 37.000 \\
HAVO/VWO & 10.000 & - & 1.000 & 14.000 \\
MBO & 43.000 & 6.000 & 59.000 \\
HBO & 21.000 & - & 6.000 & 28.000 \\
WO & 9.000 & - & 33.000 & 15.000 \\
Totaal & 147.000 & 18.000 & & 198.000 \\
& & & & \\
\hline$\quad$ minder dan 3.000 werkenden & & & & \\
\hline
\end{tabular}

Bron: ROA/CBS

Tabel 6.5 geeft aan waar de in Rotterdam werkzame bevolking woonachtig is, verbijzonderd naar opleidingsniveau. Daarmee geeft de tabel een inzicht in de structuur van de ingaande pendel van de stad Rotterdam. In deze tabel valt het grote aantal inkomende forensen met een MBO-, HBO- en WO-opleiding op. Van alle in Rotterdam werkende personen met een middelbare of hogere opleiding komt ongeveer $60 \%$ van buiten Rotterdam. Bijna de helft van alle werkenden met een WO-opleiding komt zelfs van buiten de regio Rijnmond. Voor personen met een HBO- of een MBO-opleiding bedragen de percentages respectievelijk $37 \%$ en $26 \%$. Deze drie 
groepen zijn dan ook verantwoordelijk voor ongeveer $70 \%$ van de ingaande pendel in Rotterdam. Daarentegen lijkt de werkgelegenheid voor lager opgeleiden voor het merendeel ten goede te komen voor de arbeidskrachten die in de stad zelf wonen. Dit geldt met name voor de werkgelegenheid van ongeschoolden. Ook hier blijkt echter dat nog circa $30 \%$ van de werkgelegenheid wordt opgevuld door arbeidskrachten van buiten, waarvoor bijna de helft zelfs buiten de regio Rijnmond woonachtig is.

Tabel 6.5. Overzicht van de in Rotterdam werkzame beroepsbevolking naar opleidingsniveau en woonregio, gemiddelde 1990-1991

\begin{tabular}{lccrr}
\hline Opleidingsniveau & $\begin{array}{l}\text { woonachtig in } \\
\text { Rotterdam }\end{array}$ & $\begin{array}{l}\text { woonachtig in } \\
\text { overig Rijnmond }\end{array}$ & $\begin{array}{l}\text { woonachtig in } \\
\text { overig Nederland }\end{array}$ & totaal \\
\hline Basisonderwijs & 25.000 & 6.000 & 5.000 & 36.000 \\
MAVO en onderbouw HAVO/VWO & 11.000 & 6.000 & 5.000 & 21.000 \\
LBO & 28.000 & 11.000 & 9.000 & 48.000 \\
HAVO/VWO & 10.000 & 5.000 & 4.000 & 18.000 \\
MBO & 43.000 & 34.000 & 27.000 & 104.000 \\
HBO & 21.000 & 12.000 & 19.000 & 51.000 \\
WO & 9.000 & 3.000 & 11.000 & 23.000 \\
Totaal & 147.000 & 76.000 & 79.000 & 302.000 \\
\hline
\end{tabular}

Bron: ROA/CBS 


\section{BESLUIT}

In dit rapport is een groot aantal actuele arbeidsmarktgegevens voor de regio Rijnmond gepresenteerd. Daarbij zijn de gegevens verbijzonderd naar bedrijfssector, beroep en opleiding. Dergelijke informatie is van belang voor het formuleren en uitvoeren van een adequaat arbeidsmarktbeleid. Dit geldt met name ook voor recente arbeidsmarktinformatie naar beroep en opleiding die tot op heden grotendeels ontbrak. Met deze informatie kan voor een groot deel in de behoefte aan recente en adequate arbeidsmarktinformatie voor deze regio worden voorzien.

De werkgelegenheidsstructuur in de regio Rijnmond wijkt op enkele punten belangrijk af van de landelijke werkgelegenheidsstructuur. Voor een groot deel hangt dit vanzelfsprekend samen met het typische karakter van de regio, waarbij de haven een factor van betekenis is. Met name de bedrijfssectoren 'Delfstoffenwinning en aardolie-industrie' en 'Vervoer en communicatie' zijn erg sterk in de regio vertegenwoordigd. Daarentegen is het aandeel van de sector 'Land-, tuin- en bosbouw, visserij' in de totale werkgelegenheid in de regio Rijnmond veel lager dan het landelijk gemiddelde.

De verschillen in de bedrijfssectorstructuur van de werkgelegenheid tussen Rijnmond en de rest van Nederland vinden, zoals mocht worden verwacht, hun neerslag in de beroepen- en opleidingenstructuur. Het is derhalve niet verwonderlijk dat de 'Agrarische beroepen' in Rijnmond zijn ondervertegenwoordigd. Het aandeel van de 'Economisch-administratieve beroepen' is daarentegen groot, in vergelijking met het landelijke beeld. Verder zijn bijvoorbeeld de beroepsklassen 'Scheepsofficieren, loodsen en walinspecteurs', 'Vliegers, boordwerktuigkundigen, transportdienstleiders' en 'Middelbare (scheeps)werktuigbouwkundingen e.a. metaalkundigen' sterk in de regio vertegenwoordigd.

In de regio Rijnmond zijn verhoudingsgewijs veel 'ongeschoolden' (uitsluitend basisonderwijs') werkzaam. Voor het overige wijkt de samenstelling van de werkzame bevolking, verbijzonderd naar opleidingsniveau, in Rijnmond nauwelijks af van het landelijke beeld. Wanneer echter naar de opleidingsrichtingen binnen de verschillende niveaus wordt gekeken, blijken er echter wel aanzienlijke verschillen te bestaan. Het wekt daarbij weinig verbazing dat in de regio vooral veel mensen werkzaam zijn met een opleidingsachtergrond in de vervoersrichting.

In het rapport is voorts aandacht besteed aan een aantal specifieke groepen op de arbeidsmarkt. Eerst is de arbeidsmarktpositie van vrouwen nader belicht. In het algemeen kan worden opgemerkt dat de landelijke 'vrouwensectoren', '-beroepen' en '-opleidingen' ook op regionaal niveau zijn terug te vinden. Toch zijn er enkele belangrijke verschillen. In de sector 'Overheid en onderwijs' is het percentage vrouwen in de regio Rijnmond relatief groot. De sector 'Vervoer en communicatie' wordt echter gekenmerkt door een, in vergelijking met het landelijk gemiddelde, laag aandeel van vrouwen in de werkgelegenheid, hetgeen er op wijst dat vrouwen relatief weinig profiteren van de sterke positie van deze sector in de regio. De bovengenoemde verschillen naar bedrijfssector zijn terug te vinden in de beroepen- en opleidingenstructuur van de werkgelegenheid. Zo is het aandeel van vrouwen in de 'Pedagogische beroepen' en het 
aantal vrouwen met 'HBO Onderwijs' als opleidingsachtergrond in de regio Rijnmond relatief groot, terwijl het percentage vrouwen in de 'Transportberoepen' achter blijft bij het landelijk gemiddelde.

De tweede doelgroep die in dit rapport aan de orde is geweest, betreft de werkzame bevolking van allochtone afkomst. In de regio Rijnmond wordt $10 \%$ van de totale werkgelegenheid door allochtonen vervuld, tegenover landelijk 7\%. Dit hogere percentage allochtonen doet zich in meerdere of mindere mate in alle sectoren voor. Een groot deel van de allochtone arbeidskrachten is ongeschoold (uitsluitend basisonderwijs). Met name is opvallend dat het aandeel van ongeschoolden in de totale werkgelegenheid van allochtonen in de regio Rijnmond duidelijk hoger ligt dan in de rest van Nederland.

Vervolgens is nader ingegaan op de positie van schoolverlaters op de regionale arbeidsmarkt. Het blijkt dat de werkloosheid onder schoolverlaters in de regio Rijnmond min of meer gelijk is aan het landelijk gemiddelde. Wel is het opvallend dat AVO-opgeleiden in Rijnmond verhoudingsgewijs vaak werkloos zijn, terwijl de werkloosheid onder de schoolverlaters van het LBO daarentegen relatief laag is. Daarnaast is het opmerkelijk dat de mate van onderbenutting van het opleidingsniveau van schoolverlaters voor alle onderscheiden opleidingsclusters lager is dan landelijk het geval is. Totaal gezien wordt $25 \%$ van de in Rijnmond werkende schoolverlaters onderbenut, terwijl dit landelijk $32 \%$ is. Ook de inkomenspositie van de in de regio Rijnmond werkende schoolverlaters is iets gunstiger dan het landelijke beeld. Opvallend daarbij is dat vooral (K)MBO-ers aanmerkelijk meer verdienen dan in de rest van het land. LBOschoolverlaters verdienen in de regio Rijnmond daarentegen duidelijk minder dan elders in het land. Ook meer in het algemeen kan worden geconcludeerd dat voor schoolverlaters van het (K)MBO economisch-administratief de huidige arbeidsmarktpositie in de regio Rijnmond het meest gunstig is. Aangenomen mag worden dat dit voor een belangrijk deel het gevolg is van de sterke groei van bedrijven in de financiële en zakelijke dienstverlening in de regio Rijnmond (zie voor dit laatste Atzema, Lensink en Zondag, 1992).

Een belangrijk aandachtspunt is verder geweest het verkrijgen van meer inzicht in de omvang en de aard van het forensisme. Het blijkt dat er voor de regio Rijnmond sprake is van een netto ingaande pendel van ruim 30.000 arbeidskrachten. Voor vrijwel alle bedrijfssectoren geldt daarbij dat de ingaande forensenstroom groter is dan de uitgaande stroom. Alleen voor de sectoren 'Metaalindustrie en openbare nutsbedrijven' en 'Land-, tuin- en bosbouw, visserij' is de uitgaande pendel groter dan de ingaande. De sector 'Delfstoffenwinning en aardolie-industrie' kent relatief de meeste inkomende pendelaars. Opvallend is dat de totale ingaande pendel maar liefst meer dan het vijfvoudige bedraagt van het genoemde pendelsaldo. Dit wijst op discrepanties tussen de opleidingenstructuur van het arbeidsaanbod en de arbeidsvraag in de regio Rijnmond.

Wanneer de omvang van de pendelstromen wordt verbijzonderd naar opleidingsniveau, dan blijkt dat op alle niveaus de ingaande pendel groter is dan de uitgaande pendel. Vooral bij de hogere opleidingsniveaus is er sprake van omvangrijke pendelstromen. Zo woont maar liefst bijna de 
helft van alle in Rijnmond werkzame academici niet in de regio. Daarentegen is ruim een derde van alle in Rijnmond wonende academici buiten de regio werkzaam.

Tenslotte is in dit rapport in het bijzonder aandacht besteed aan de positie van de stad Rotterdam. In de stad is ruim twee derde van de totale werkgelegenheid van de regio Rijnmond geconcentreerd. De opleidingenstructuur van de werkgelegenheid is derhalve niet of nauwelijks verschillend van de werkgelegenheidsstructuur van Rijnmond als geheel. Wel is er sprake van relatief omvangrijke pendelstromen van en naar Rotterdam. Van alle in Rotterdam werkzame personen is slechts ongeveer de helft ook in de stad woonachtig. Een kwart van de in Rotterdam werkzame arbeidskrachten pendelt vanuit de rest van de regio Rijnmond, terwijl een even groot deel van de werkenden van buiten de regio komt. De uit Rotterdam gaande pendel is daarentegen veel geringer van omvang.

Eén van de belangrijkste resultaten van dit onderzoek is dat voor vrijwel alle bedrijfssectoren het percentage ongeschoolden in Rijnmond hoger is dan in de rest van Nederland. Dit duidt er op dat dit relatief hoge percentage lager opgeleiden in de werkzame bevolking voor de regio Rijnmond niet zozeer samenhangt met de structuur van de werkgelegenheid in de regio, maar met de structuur van het arbeidsaanbod. Voor een deel hangt dit weer samen met de relatieve oververtegenwoordiging van allochtonen in Rijnmond. Ook de omvangrijke pendelstromen van met name middelbaar en hoger opgeleiden naar de regio Rijnmond wijzen op scheve verhoudingen in de opleidingenstructuur van het arbeidsaanbod.

Tenslotte wordt opgemerkt dat de in dit rapport beschreven actuele arbeidsmarktgegevens slechts een eerste, weliswaar belangrijke en noodzakelijke, stap vormen bij het voeren van een adequaat regionaal werkgelegenheidsbeleid. Voor een dergelijk beleid is het immers vooral ook van belang inzicht te krijgen in de te verwachten toekomstige ontwikkelingen op de arbeidsmarkt. Daarbij moet de blik niet uitsluitend zijn gericht op de werkgelegenheidsontwikkeling. De vervangingsvraag als gevolg van pensionering, tijdelijke terugtreding van de arbeidsmarkt e.d. is doorgaans een veel belangrijkere component van de totale vraag naar nieuwkomers (zie De Grip, Meijboom en Willems, 1993). Daarnaast is het van belang deze vraagprognoses te confronteren met gegevens over de verwachte instroom van nieuwkomers (schoolverlaters en kortdurig werklozen) op de arbeidsmarkt (zie ook ROA, 1992 en Berendsen, De Grip, Wieling en Willems, 1992). Op die manier kan een indicatie worden verkregen van de ruimte of spanning die in de toekomst op de regionale arbeidsmarkt, verbijzonderd naar beroep en opleiding, kan worden verwacht. Ook kan zo verder uitsluitsel worden gegeven over de toekomstige arbeidsmarktpositie van ongeschoolden in verhouding tot de arbeidsmarktperspectieven van deze groep in de rest van Nederland. 


\section{LITERATUUR}

Atzema, O., E. Lensink, H. Zondag (1992), Economische dynamiek en werkgelegenheid in de Randstad, Stedelijke Netwerken Werkstukken 47, Utrecht.

Atzema, O., E. Ram (1992), Spreiding van de beroepsbevolking in de Randstad anno 1990, Stedelijke Netwerken Werkstukken 46, Utrecht.

Berendsen, H., A. de Grip, M.H. Wieling, E.J.T.A. Willems (1992), Arbeidsmarktinformatie naar opleiding en beroep voor de provincie Noord-Holland, ROA-R-1992/3, Maastricht.

CBS (1991), Regionaal Statistisch Zakboek 1991, SDU-Uitgeverij, 's-Gravenhage.

CBS (1992), Statistiek van de Zeevaart 1991, Voorburg/Heerlen.

CBS (1993), Enquête Beroepsbevolking 1992, Voorburg/Heerlen.

CPB (1992), Nederland in Drievoud; een scenariostudie van de Nederlandse economie 1990 2015, SDU-Uitgeverij, 's-Gravenhage.

Heijke, J.A.M. (1993), Achtergronden en opzet van het Informatiesysteem Onderwijs-Arbeidsmarkt van het ROA, in: R.M.H. Spijkerman, A.J.R. Vincken, M.J.M. Weekenborg (red.), Handboek Studie- en Beroepskeuzebegeleiding, Samsom H.D. Tjeenk Willink, Alphen aan den Rijn, blz. 2050/1-2050/30.

Grip, A. de, J.A.M. Heijke (1993), De aansluiting onderwijs-arbeidsmarkt: regionale arbeidsmarktinformatie, in: Werkgroep Regionale Arbeidsmarkt, Onderwijs en Arbeidsmarkt in de regio, te verschijnen.

Grip, A. de, P. Meijboom, E. Willems (1993), Vacancies, Employment Growth, and the Demand for Newcomers on the Labour Market, ROA-RM-1993/1E, Maastricht.

Grip, A. de, R.K.W. van der Velden, M.H. Wieling (1993), De inpassing van schoolverlatersinformatie in het ROA-informatiesysteem onderwijs-arbeidsmarkt, ROA, te verschijnen.

Grip, A. de, J.A.M. Heijke, E.J.T.A. Willems (1992), Scholing en mobiliteit, Maandschrift Economie, jrg. 56, blz. 131-144.

Groot, L.F.M. (1990), De onderwijs- en beroepssegregatie tussen mannen en vrouwen in de eerste helft van de jaren tachtig, Tijdschrift voor Arbeidsvraagstukken, jrg. 6, nr. 4, blz. 4-12.

Loo, P.J.E. van de, R.J.P. Dekker, A. de Grip (1992), Arbeidsmarktsegmentatie als uitgangspunt voor een beroepenclassificatie, Tijdschrift voor Arbeidsvraagstukken, jrg. 8, nr. 1, blz. 19-31. 
$-42-$

Mourik, A. van, J.J. Siegers (1988), Ontwikkelingen in de beroepssegregatie tussen mannen en vrouwen 1971-1985, Economisch Statistische Berichten, jrg. 73, nr. 3668, blz. 732-737.

Ministerie van Sociale Zaken en Werkgelegenheid (1990), Rapportage arbeidsmarkt 1990, 'sGravenhage.

ROA (1992), De arbeidsmarkt naar opleiding en beroep tot 1994, ROA-R-1992/1, Maastricht.

Siegers, J.J. (1979), Beroepssegregatie tussen mannen en vrouwen in Nederland, Economische Statistische Berichten, jrg. 64, nr. 3194, blz. 208-213.

Wieling, M.H., P.J.E. van de Loo, R.K.W. van der Velden (1993), Waar komen onze schoolverlaters terecht? De uitstroom en bestemming van het schooljaar 1990/1991, LDC, Leeuwarden.

Windmeyer, F. (1992), De regionale dimensie van de arbeidsmarkt, OSA W108, Den Haag. 


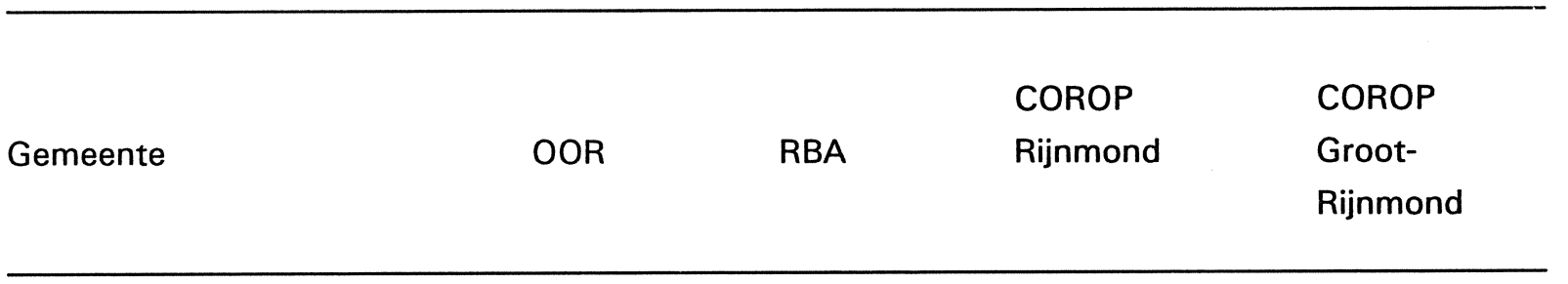

$\begin{array}{ll}\text { Albrandswaard } & x \\ \text { Barendrecht } & x \\ \text { Bergschenhoek } & x \\ \text { Berkel en Rodenrijs } & x \\ \text { Bernisse } & x \\ \text { Binnenmaas } & \end{array}$

$\begin{array}{ll}x & x \\ x & x\end{array}$

$x \quad x$

$x \quad x$

$x \quad x$

$x \quad x$

Binnenmaas

1)

Bleiswijk

Brielle

Capelle a/d IJssel

$\mathrm{x}$

Cromstrijden

Dirksland

Goedereede

Heerjansdam

Hellevoetsluis

X

Korendijk

Krimpen a/d IJssel

Maassluis

$x$

X

X

Middelharnis

Nederlek

Nieuwerkerk a/d IJssel

Oostflakkee

Ouderkerk

Oud-beijerland

Ridderkerk

Rotterdam

Rozenburg

Schiedam

Spijkenisse

Strijen

Vlaardingen

Westvoorne $x$

$x$

$x$
$x$
$x$
$x$
$x$
$x$

$x$

$x$

$x$

$x$

$x$

$x$

$x$

$x$

$x$

$\mathrm{x}$

$x$

$\mathbf{x}$

$\mathrm{x}$

$\mathrm{x}$

$x$

$\mathrm{x}$

$x \quad x$

$x$

x $x$

$x \quad x$

$x \quad x$

$x \quad x$

$x \quad x$

$x$

$x \quad x$

$x \quad x$

$x \quad x$

$x \quad x$

$x$

$x$

$x$

$x$

$x$

$x$

$x \quad x$

$x \quad x$

$x \quad x$

$x \quad x$

$x$

$x$

$\begin{array}{ll}x & x \\ x & x\end{array}$

$x$

$x$

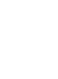

$\mathrm{x}$

1) Pas sinds kort aangesloten bij het OOR. In dit rapport wordt deze gemeente nog niet tot de regio Rijnmond gerekend. 


\title{
BIJLAGE B. OVERZICHT VAN BEDRIJFSSECTOREN
}

\author{
Bedrijfssector \\ SBI-codijbehorende bedrijfsklassen
}

\begin{tabular}{|c|c|c|}
\hline & SBI-code & naam \\
\hline Land-, tuin- en bosbouw, visserij & $\begin{array}{l}1 \\
2 \\
3\end{array}$ & $\begin{array}{l}\text { Land- en tuinbouw } \\
\text { Bosbouw } \\
\text { Visserij }\end{array}$ \\
\hline \multirow[t]{2}{*}{ Chemische industrie } & $\begin{array}{l}11 \\
29 \\
30\end{array}$ & $\begin{array}{l}\text { Kolenmijnbouw e.d. } \\
\text { Chemische industrie } \\
\text { Kunstmatige en synthetische garen- en vezelin- } \\
\text { dustrie }\end{array}$ \\
\hline & $\begin{array}{l}31 \\
33\end{array}$ & $\begin{array}{l}\text { Rubber- en kunststofverwerkenden industrie } \\
\text { Basismetaalindustrie }\end{array}$ \\
\hline \multirow{6}{*}{ Metaalindustrie en openbare nutsbedrijven } & 34 & $\begin{array}{l}\text { Metaalproduktenindustrie (excl. machines en } \\
\text { transportmiddelen) }\end{array}$ \\
\hline & 35 & Machine-industrie \\
\hline & $\begin{array}{l}36 \\
37\end{array}$ & $\begin{array}{l}\text { Elektrotechnische industrie } \\
\text { Transportmiddelenindustrie }\end{array}$ \\
\hline & 38 & Instrumenten- en optische industrie \\
\hline & 39 & Overige industrie \\
\hline & 40 & Openbare nutsbedrijven \\
\hline \multirow[t]{2}{*}{ Delfstoffenwinning en aardolie industrie } & $\begin{array}{l}12 \\
19\end{array}$ & $\begin{array}{l}\text { Aardolie- en aardgaswinning en exploitatie } \\
\text { Overiqe delfstoffenwinning }\end{array}$ \\
\hline & 28 & Aardolie-industrie \\
\hline \multirow[t]{7}{*}{ Overige industrie } & $20 / 21$ & Voedings- en genotmiddelenindustrie \\
\hline & 22 & Textielindustrie \\
\hline & 23 & Kledingindustrie \\
\hline & 24 & $\begin{array}{l}\text { Leder-, schoen- e.a. lederwarenindustrie lexcl. } \\
\text { kleding) }\end{array}$ \\
\hline & 25 & $\begin{array}{l}\text { Hout- en meubelindustrie (excl. metalen meube- } \\
\text { len) }\end{array}$ \\
\hline & 26 & Papier- en papierwarenindustrie \\
\hline & $\begin{array}{l}27 \\
32\end{array}$ & $\begin{array}{l}\text { Grafische industrie, uitgeverijen } \\
\text { Bouwmaterialen-, aardewerk- en glasindustrie }\end{array}$ \\
\hline \multirow[t]{2}{*}{ Bouwnijverheid en bouwinstallatiebedrijven } & 51 & Bouwnijverheid \\
\hline & 52 & Bouwinstallatiebedrijven e.d. \\
\hline \multirow[t]{2}{*}{ Groothandel en reparatiebedrijven } & $61 / 64$ & Groothandel, tussenpersonen in de handel \\
\hline & 68 & Reparatiebedrijven voor gebruiksgoederen \\
\hline \multirow[t]{2}{*}{ Detailhandel en horeca } & $65 / 66$ & Detailhandel \\
\hline & 67 & Hotels, restaurants, café's e.d. \\
\hline \multirow[t]{6}{*}{ Vervoer en communicatie } & 71 & Spoorwegen \\
\hline & $\begin{array}{l}72 \\
73\end{array}$ & $\begin{array}{l}\text { Wegvervoer } \\
\text { Zeevaart }\end{array}$ \\
\hline & $\begin{array}{l}73 \\
74\end{array}$ & $\begin{array}{l}\text { Zeevaart } \\
\text { Binnenvaart }\end{array}$ \\
\hline & 75 & $\begin{array}{l}\text { Binnenvaart } \\
\text { Luchtvaart }\end{array}$ \\
\hline & 76 & $\begin{array}{l}\text { Luchtvaart } \\
\text { Hulpbedrijven van het vervoer }\end{array}$ \\
\hline & 77 & Communicatiebedrijven \\
\hline \multirow[t]{2}{*}{ Bank- en verzekeringswezen } & 81 & Bankwezen \\
\hline & 82 & Verzekeringswezen \\
\hline \multirow[t]{3}{*}{ Overige tertiaire dienstverlening } & 83 & $\begin{array}{l}\text { Exploitatie van en handel in onroerende goederen } \\
\text { e.d. }\end{array}$ \\
\hline & 84 & Zakelijke dienstverlening \\
\hline & 85 & Verhuur en machines e.a. roerende goederen \\
\hline \multirow[t]{2}{*}{ Overheid en onderwijs } & 90 & $\begin{array}{l}\text { Openbaar bestuur, defensie en wettelijke sociale } \\
\text { verzekering }\end{array}$ \\
\hline & 92 & Onderwijs \\
\hline \multirow[t]{6}{*}{ Overige kwartaire dienstverlening } & 91 & Religieuze organisaties e.d. \\
\hline & 93 & Gezondsheids- en veterinaire diensten \\
\hline & 94 & Maatschappelijke dienstverlening \\
\hline & $\begin{array}{l}95 \\
96\end{array}$ & $\begin{array}{l}\text { Sociaal-culturele en culturele instellingen } \\
\text { Sport en recreatie }\end{array}$ \\
\hline & 97 & $\begin{array}{l}\text { Bedrijfs- en werknemersorganisaties, research- } \\
\text { instellingen, overige sociale organisaties }\end{array}$ \\
\hline & 98 & Overige dienstverlenende bedrijven \\
\hline
\end{tabular}




\section{BIJLAGE C. STATISTISCH SUPPLEMENT}

Tabel C.1. Aantal werkenden naar bedrijfssector en geslacht in de regio Rijnmond en in geheel Nederland, gemiddelde 1989-1991

\begin{tabular}{|c|c|c|c|c|c|c|}
\hline \multirow[t]{2}{*}{ Bedrijfssector } & \multirow[b]{2}{*}{ mannen } & \multicolumn{2}{|c|}{ Rijnmond } & \multirow[b]{2}{*}{ mannen } & \multicolumn{2}{|c|}{ Nederland } \\
\hline & & vrouwen & totaal & & vrouwen & totaal \\
\hline Land-, tuin- en bosbouw, visserij & 5.000 & . & 6.500 & 198.000 & 93.500 & 261.500 \\
\hline Chemische industrie & 12.500 & & 14.000 & 113.500 & 23.000 & 137.000 \\
\hline Metaalindustrie en openbare nutsbedrijven & 29.500 & 4.500 & 33.500 & 488.500 & 74.500 & 563.000 \\
\hline Delfstoffenwinning en aardolie industrie & 6.500 & & 7.000 & 19.500 & 2.500 & 22.000 \\
\hline Overige industrie & 13.500 & 5.500 & 19.000 & 317.500 & 111.000 & 428.500 \\
\hline Bouwnijverheid en bouwinstallatiebedrijven & 28.000 & 2.000 & 30.000 & 371.500 & 22.500 & 394.000 \\
\hline Groothandel en reparatiebedrijven & 28.500 & 7.500 & 36.500 & 337.500 & 96.500 & 434.500 \\
\hline Detailhandel en horeca & 19.000 & 22.000 & 41.000 & 266.500 & 298.000 & 564.500 \\
\hline Vervoer en communicatie & 46.000 & 8.500 & 55.000 & 290.500 & 63.500 & 354.000 \\
\hline Bank- en verzekeringswezen & 13.500 & 8.500 & 22.000 & 125.000 & 85.500 & 210.500 \\
\hline Overige tertiaire dienstverlening & 26.000 & 12.000 & 38.000 & 252.500 & 128.500 & 381.000 \\
\hline Overheid en onderwijs & 33.500 & 22.500 & 56.500 & 575.500 & 283.500 & 859.000 \\
\hline Overige kwartaire dienstverlening & 25.000 & 55.000 & 80.000 & 332.000 & 673.500 & 1005.500 \\
\hline Totaal & 289.000 & 153.500 & 442.500 & 3.714 .500 & 1.945 .500 & 5.660 .000 \\
\hline
\end{tabular}

Bron: CBS/ROA

Tabel C.2. Aantal werkenden naar bedrijfssector en geslacht in de regio Rijnmond als percentage van het aantal werkenden naar bedrijfssector en geslacht in geheel Nederland, gemiddelde 1989-1991

\begin{tabular}{|c|c|c|c|}
\hline Bedrijfssector & mannen & $\begin{array}{l}\text { Rijnmond } \\
\text { vrouwen }\end{array}$ & totaal \\
\hline Land-, tuin- en bosbouw, visserij & 3 & . & 3 \\
\hline Chemische industrie & 11 & . & 10 \\
\hline Metaalindustrie en openbare nutsbedrijven & 6 & 6 & 6 \\
\hline Delfstoffenwinning en aardolie industrie & 33 & . & 32 \\
\hline Overige industrie & 4 & 5 & 4 \\
\hline Bouwnijverheid en bouwinstallatiebedrijven & 8 & 9 & 8 \\
\hline Groothandel en reparatiebedrijven & 8 & 8 & 8 \\
\hline Detailhandel en horeca & 7 & 7 & 7 \\
\hline Vervoer en communicatie & 16 & 13 & 16 \\
\hline Bank- en verzekeringswezen & 11 & 10 & 11 \\
\hline Overige tertiaire dienstverlening & 10 & 9 & 10 \\
\hline Overheid en onderwijs & 6 & 8 & 7 \\
\hline Overige $\mathrm{kwartaire}$ dienstverlening & 8 & 8 & 8 \\
\hline Totaal & 8 & 8 & 8 \\
\hline
\end{tabular}


$-46-$

Tabel C.3. Percentage vrouwen naar bedrijfssector in de regio Rijnmond en in geheel Nederland, gemiddelde 19891991

$\begin{array}{lcc}\text { Bedrijfssector } & \text { Rijnmond } & \text { Nederland } \\ \% & \% & \%\end{array}$

Land-, tuin- en bosbouw, visserij

Chemische industrie

Metaalindustrie en openbare nutsbedrijven

. $\quad 36$

Delfstoffenwinning en aardolie industrie

Overige industrie

Bouwnijverheid en bouwinstallatiebedrijven

Groothandel en reparatiebedrijven

13

Detailhandel en horeca

Vervoer en communicatie

29

7

21

54

Bank- en verzekeringswezen

Overige tertiaire dienstverlening

Overheid en onderwijs

Overige kwartaire dienstverlening

. = minder dan 2.000 werkenden 
Tabel C.4. Aantal werkenden naar beroepsklasse en geslacht in de regio Rijnmond en in geheel Nederland, gemiddelde 1989-1991

\begin{tabular}{|c|c|c|c|c|c|c|c|}
\hline \multirow{2}{*}{$\begin{array}{l}\text { ROA- } \\
\text { code }\end{array}$} & \multirow[t]{2}{*}{ beroepsklasse } & \multicolumn{3}{|c|}{ Rijnmond } & \multicolumn{3}{|c|}{ Nederland } \\
\hline & & mannen & vrouwen & totaal & mannen & vrouwen & totaal \\
\hline 0 & PEDAGOGISCHE BEROEPEN & 11.000 & 11.000 & 22.000 & 168.500 & 127.000 & 296.000 \\
\hline 01 & Onderwijs(kundige) beroepen & 11.000 & 11.000 & 21.500 & 163.000 & 123.000 & 286.000 \\
\hline 0131 & $\begin{array}{l}\text { Leerkrachten basis- en } \\
\text { speciaal onderwijs }\end{array}$ & 2.000 & 6.000 & 8.000 & 37.000 & 63.000 & 100.000 \\
\hline 0132 & $\begin{array}{l}\text { Docenten voortgezet en } \\
\text { hoger onderwijs }\end{array}$ & 7.000 & 4.000 & 11.000 & 97.500 & 50.500 & 147.500 \\
\hline 0133 & $\begin{array}{l}\text { Schoolhoofden e.a. } \\
\text { onderwijskundige beroepen }\end{array}$ & 2.000 & $\cdot$ & 3.000 & 29.000 & 10.000 & 38.500 \\
\hline 02 & Sport(instructieve) beroepen & - & . & . & 5.500 & 4.000 & 9.500 \\
\hline 0221 & $\begin{array}{l}\text { Sportinstructeurs, officials, } \\
\text { beroepssportlieden }\end{array}$ & $\cdot$ & $\cdot$ & - & 5.500 & 4.000 & 9.500 \\
\hline 1 & CULTURELE BEROEPEN & 2.500 & $\cdot$ & 4.000 & 46.000 & 30.500 & 76.500 \\
\hline 11 & Taal- en letterkundige beroepen & . & . & . & 2.000 & 4.000 & 6.000 \\
\hline 1131 & $\begin{array}{l}\text { Taal- en letterkundigen, } \\
\text { vertalers, tolken }\end{array}$ & · & $\cdot$ & . & 2.000 & 4.000 & 6.000 \\
\hline 12 & Theologische beroepen & · & · & . & 7.000 & $\cdot$ & 8.500 \\
\hline 1231 & Pastorale beroepen & . & . & . & 7.000 & . & 8.500 \\
\hline 13 & Kunst- en vormgevende beroepen & 2.500 & . & 3.500 & 36.500 & 25.500 & 62.000 \\
\hline 1321 & Fotografen, filmers, vormgevers, etaleu & urs & . & • & 20.000 & 11.500 & 31.500 \\
\hline 1331 & Beeldende en uitvoerende kunstenaars & . & - & - & 16.500 & 14.000 & 30.500 \\
\hline 2 & AGRARISCHE BEROEPEN & 6.500 & 2.000 & 8.000 & 224.000 & 60.000 & 284.000 \\
\hline 20 & Agrarische beroepen & 6.500 & 2.000 & 8.000 & 224.000 & 60.000 & 284.000 \\
\hline 2011 & $\begin{array}{l}\text { Uitvoerend agrarisch personeel, } \\
\text { bosarbeiders }\end{array}$ & 4.000 & . & 5.500 & 94.000 & 47.500 & 141.500 \\
\hline 2012 & Zelfstandige agrariërs, boswachters & 2.500 & . & 2.500 & 126.500 & 12.000 & 138.500 \\
\hline 2031 & Landbouwkundige vakspecialisten & $\cdot$ & - & $\cdot$ & 3.500 & • & 3.500 \\
\hline 3 & TECHNISCHE, AMBACHTS- EN & & & & & & \\
\hline & INDUSTRIEBEROEPEN & 20.000 & 7.000 & 127.000 & 1.524 .000 & 127.000 & .651 .000 \\
\hline 30 & $\begin{array}{l}\text { Technische, ambachts-en industrie- } \\
\text { beroepen }\end{array}$ & 42.500 & 3.000 & 45.500 & 482.000 & 41.500 & 524.000 \\
\hline 3011 & Heftruck- en hefvorkchauffeurs & 2.000 & • & 2.000 & 22.000 & . & 22.000 \\
\hline 3012 & Machinisten bouw en industrie & 3.500 & . & 4.000 & 31.000 & . & 31.000 \\
\hline 3021 & $\begin{array}{l}\text { Directeuren, bedrijfsleiders, } \\
\text { leidinggevenden industrie }\end{array}$ & 17.000 & . & 18.000 & 207.000 & 19.500 & 226.500 \\
\hline 3022 & $\begin{array}{l}\text { Technische en medische } \\
\text { vertegenwoordigers }\end{array}$ & & . & $\cdot$ & 5.500 & . & 6.500 \\
\hline 3023 & Technische tekenaars & 3.500 & . & 4.000 & 36.000 & . & 37.500 \\
\hline 3024 & Technische analisten, amanuenses & 2.000 & . & 2.500 & 23.500 & 8.000 & 31.000 \\
\hline 3031 & $\begin{array}{l}\text { Bèta-onderzoekers, technische } \\
\text { vakspecialisten }\end{array}$ & 4.000 & . & 4.500 & 48.000 & 6.000 & 54.000 \\
\hline 31 & Voedings- en genotmiddelenberoepen & 3.000 & . & 3.500 & 58.500 & 10.000 & 69.000 \\
\hline 3111 & Voedingsmiddelenbereiders & 2.000 & . & 2.500 & 37.000 & 7.500 & 45.000 \\
\hline 3112 & $\begin{array}{l}\text { (Zelfstandige) bakkers e.a. } \\
\text { (industrieel) bakkerijpersoneel }\end{array}$ & · & - & - & 21.500 & 2.500 & 24.000 \\
\hline 32 & Textielberoepen & . & . & 2.000 & 25.000 & 25.000 & 50.500 \\
\hline 3211 & Produktiepersoneel textielindustrie & • & . & • & 8.000 & 2.000 & 10.000 \\
\hline 3212 & Stoffeerders, schoen- e.a. lederwarenn & makers. & . & . & 14.000 & 5.500 & 19.500 \\
\hline
\end{tabular}


3213 Kleding- e.a. textiel- en bontproduktenmakers

5.500

3.500

17.500

21.000

33 Hout- en papierberoepen

5.500

129.000

$2.500 \quad 131.500$ papier- en kartonmakers

3312 Houtbewerkers, timmerlieden

$5.500^{\circ}$

11.500

117.500

12.500

2.500

3.500

43.500

119.000

$34 \quad$ Grafische beroepen

3.500

43.500

12.000

55.500

3411 Drukkers, boekbinders, fotolaboranten 2.500

5.000

27.000

12.000

55.500

35 Chemische beroepen 5.000

5.000

27.000

$2.000 \quad 28.500$

3511 Produktiepersoneel chemische industrie 5.000

26.000

317.500

$2.000 \quad 28.500$

3611 Delfstoffen(be)werkers, metaalvervaardigers .

13.500

$9.500 \quad 327.500$

3612 Machinale metaalbewerkers

3613 Lassers, constructiewerkers, edelmetaalsmeden

5.500

34.500

$4.000 \quad 38.000$

5.500

58.500

$2.000 \quad 60.500$

3614 Machinebank- en plaatwerkers, gereedschaps- en modelmakers

3615 Onderhoudsmonteurs, fietsen- en

6.000

6.000

73.000

74.000

4.500

66.000

$2.000 \quad 68.000$

4.000

45.000

2.000

12.500

14.500

12.000

139.000

$12.000 \quad 151.000$

3711 Samenstellers elektrotechnische produkten kwaliteitscontroleurs

3712 Lijnwerkers, kabelmonteurs en -lassers

3721 Elektriciens, elektro- en telecom(onderhouds)monteurs $\quad \mathbf{8 . 5 0 0}$

3722 Middelbare elektrotechnici

3731 Hogere elektrotechnici

16.500

3.500

$8.500 \quad 25.000$

8.500

95.500

4.500

18.500

$3.000 \quad 99.000$

.$\quad 4.500$

19.000

38 Bouwmaterialen-, glas- en aardewerkberoepen

3811 Produktiepersoneel bouwmaterialen-, glas- en aardewerkindustrie

$\begin{array}{rrrr}2.000 & 36.000 & 4.500 & 40.000 \\ 2.000 & 36.000 & 4.500 & 40.000 \\ 22.500 & 266.000 & 7.500 & 274.000\end{array}$

39 Bouw - en installatieberoepen

22.500

47.000

47.000

straatmakers, stukadoors

2.500

2.500

21.500

2.000

32.500

22.000

isoleerders, glaszetters

2.000

3913 Huis-, scheeps- en constructieschilders 2.500

2.500

45.500

32.500 -reparateurs

5.000

5.000

71.000

45.500

3915 Overige bouwvaklieden, (spoor)weg- en reinigingswerkers

6.000

6.000

22.000

$5.000 \quad 76.000$ werkvoorbereiders

2.000

2.000

26.500

22.500

3931 Architecten, geodeten

e.a. hogere bouwkundigen

2.500

3.000

286.000

28.000

4 TRANSPORTBEROEPEN

31.000

2.000

33.000

$41.500 \quad 328.000$

7.000

8.000

84.500

$33.500 \quad 118.000$

4011 Laders, lossers, vul- en inpak(machine)bedienden

7.000

8.000

84.500

$33.500 \quad 118.000$

41 Maritieme e.a. Waterwegtransportberoepen

4.500

4.500

16.000

16.000

4111 Vissers, vis- en schaaldierkwekers, jagers e.d. 
4112 Matrozen e.a. scheepsdek- en machinekamerpersoneel

4121 Scheepsofficieren, loodsen, walinspecteurs

42 Rail- en wegtransportberoepen

4211 Conducteurs, chauffeurs

e.a. transportmiddelenbestuurders

43 Lucht- en overige transportberoepen 5.000

4321 Vliegers, boordwerktuigkundigen, transportdienstleiders

5.000

5 MEDISCHE EN PARAMEDISCHE BEROEPEN

7.000

$\begin{array}{ll} & \text { logopedisten, pedicuren } \\ 5031 & \text { Fysio-, arbeids- e.a. bewegingstherapeuten } \\ 5032 & \text { Radiologische, medische en }\end{array}$ biologische laboranten

5033 Geneeskundigen, medische adviseurs, apothekers

2.500

5034 Diergeneeskundigen, veterinaire geneeskundigen

5035 Tandheelkundigen en

tandheelkundige specialisten

6 ECONOMISCH-ADMINISTRATIEVE BEROEPEN

86.000

72.000

158.000

2.000

9.500

60 Economisch-administratieve beroepen 7.500

7.500

2.000

61 Administratieve beroepen

49.000

6111 Postdistributiepersoneel

2.500

6112 Datatypisten, computeroperators

6121 Administratief leidinggevenden

6122 Secretaressen, typisten

3.500

6123 Bibliotheekassistenten

6124 Boekhoudkundige, belasting-, loketen bankemployees

6125 Commercieel-administratieve employees

6126 Telefonisten, balie-employees, enquêteurs e.d.

6131 Systeemanalisten, -programmeurs en -beheerders

6132 Accountants, economen e.a. economische specialisten

62 Commerciële beroepen

6211 Winkel-, straat- en marktverkopers, demonstrateurs

6221 Winkeliers e.a. detail- en groothandelaren

$52.000 \quad 101.000$

$12.000 \quad 12.000$

13.500

16.000

29.500

14.500

13.500

28.000

5.000

8.500

4.000

26.000

7.000

17.500

13.500

8.000

. 10.000

2.000
9.500 3.000

5.000

2.000

6.500

4.500

8.000

158.500

158.500

27.500

27.500

99.500

290.000

389.500

99.500

290.000

389.500

23.500

$94.000 \quad 117.500$

13.000

$91.000 \quad 103.500$

$21.500 \quad 21.500$

$3.000 \quad 11.000 \quad 14.000$

$\begin{array}{lll}6.000 & 17.500 \quad 23.500\end{array}$

$\begin{array}{lll}12.500 & 25.500 \quad 38.500\end{array}$

$8.500 \quad 18.000 \quad 27.000$

25.500

3.000

$9.500 \quad 35.000$

4.500

3.500

6.000

$985.500 \quad 845.5001 .831 .000$

$80.500 \quad 18.500 \quad 99.000$

$80.500 \quad 18.500 \quad 99.000$

$548.000 \quad 597.5001 .146 .000$

$\begin{array}{lll}33.000 & 9.000 \quad 41.500\end{array}$

$\begin{array}{lll}7.000 & 8.000 & 14.500\end{array}$

$\begin{array}{lll}31.500 & 11.500 \quad 43.000\end{array}$

$3.000 \quad 138.500 \quad 141.000$

$\begin{array}{lll}7.500 & 13.000 \quad 20.500\end{array}$

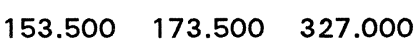

$\begin{array}{lll}156.000 & 163.000 \quad 319.000\end{array}$

$15.500 \quad 60.000 \quad 76.000$

$\begin{array}{llll}9.500 & 99.000 & 13.500 & 112.500\end{array}$

4.500

42.000

$8.000 \quad 50.500$

312.000

$215.000 \quad 527.000$

$86.500 \quad 159.000 \quad 245.500$

$\begin{array}{lll}117.000 & 32.000 \quad 149.000\end{array}$

$108.500 \quad 24.000 \quad 132.500$ 
$-50-$

63 Bestuurlijke en juridische beroepen 3.500

6331 Leden en leidinggevenden openbaar bestuur, beleidsambtenaren $\quad 2.000$

6332 Juristen

2.000

. 4.000

45.000

14.000

59.000

7 SOCIAAL-CULTURELE BEROEPEN

5.500

7.000

2.000

24.500

5.000

30.000

70 Sociaal-culturele beroepen

5.500

7.000

12.500

9.000

29.500

7021 Auteurs, journalisten, nieuwslezers, presentatoren

12.500

82.500

$83.500 \quad 166.000$

7031 Bibliothecarissen, archivarissen, conservatoren

2.000

82.500

$83.500 \quad 166.000$

18.000

$14.000 \quad 31.500$

7032 Personeels- en beroepenspecialisten. arbeidsbemiddelaars

7033 Maatschappelijk werkers, reclasseringsambtenaren

7034 Sociale wetenschapsbeoefenaren

7035 Overige sociaal-culturele en commerciële vakspecialisten

$\begin{array}{lll}6.500 & 7.500 \quad 14.000\end{array}$

VERZORGENDE EN DIENSTVERLENENDE BEROEPEN

11.500

27.000

39.000

148.500

330.500

479.000

81 Horecaberoepen

8.000

7.000

15.000

89.000

$93.500 \quad 182.500$

serveerpersoneel

5.000

6.000

11.000

53.500

$70.500 \quad 124.000$

8121 Houders en leidinggevenden horeca- en recreatiebedrijven

2.500

4.000

35.500

$23.000 \quad 58.500$

82 Verzorgende beroepen

4.000

20.000

24.500

60.000

$237.000 \quad 297.500$

lager dienstverlenend personeel

3.500

8.500

12.000

50.500

$99.000 \quad 149.500$

9.000

9.500

$2.500 \quad 111.500 \quad 114.500$

e.a. verzorgend personeel

2.500

3.000

6.500

$26.500 \quad 33.500$

9 OPENBARE ORDE- EN VEILIGHEIDSBEROEPEN

6.000

7.000

89.000

$6.000 \quad 95.000$

91 Politie-, brandweer-en bewakingsberoepen

$\begin{array}{llllll}5.500 & \cdot & 6.000 & 52.000 & 5.000 & 57.000\end{array}$

9121 Politie-, brandweer- en bewakingspersoneel

5.500

6.000

52.000

5.000

57.000

37.000

38.000

92 Militaire beroepen

37.000

38.000

Totaal (incl. beroep onbekend)

$289.000 \quad 153.500 \quad 442.500$ 
Tabel C.5. Aantal werkenden naar beroepsklasse en geslacht in de regio Rijnmond als percentage van het aantal werkenden naar beroepsklasse en geslacht in geheel Nederland, gemiddelde 1989-1991

\begin{tabular}{|c|c|c|c|c|}
\hline $\begin{array}{l}\text { ROA- } \\
\text { code }\end{array}$ & beroepsklasse & mannen & $\begin{array}{l}\text { Rijnmond } \\
\text { vrouwen }\end{array}$ & totaal \\
\hline 0 & PEDAGOGISCHE BEROEPEN & 7 & 9 & 7 \\
\hline 01 & Onderwijs(kundige) beroepen & 7 & 9 & 8 \\
\hline 0131 & $\begin{array}{l}\text { Leerkrachten basis- en } \\
\text { speciaal onderwijs }\end{array}$ & 5 & 10 & 8 \\
\hline 0132 & $\begin{array}{l}\text { Docenten voortgezet en } \\
\text { hoger onderwijs }\end{array}$ & 7 & 8 & 7 \\
\hline 0133 & $\begin{array}{l}\text { Schoolhoofden e.a. } \\
\text { onderwijskundige beroepen }\end{array}$ & 7 & . & 8 \\
\hline $\begin{array}{l}02 \\
0221\end{array}$ & $\begin{array}{l}\text { Sport(instructieve) beroepen } \\
\text { Sportinstructeurs, officials, } \\
\text { beroepssportlieden }\end{array}$ & . & . & $\cdot$ \\
\hline 1 & CULTURELE BEROEPEN & 5 & . & 5 \\
\hline $\begin{array}{l}11 \\
1131\end{array}$ & $\begin{array}{l}\text { Taal- en letterkundige beroepen } \\
\text { Taal- en letterkundigen, } \\
\text { vertalers, tolken }\end{array}$ & . & . & . \\
\hline $\begin{array}{l}12 \\
1231\end{array}$ & $\begin{array}{l}\text { Theologische beroepen } \\
\text { Pastorale beroepen }\end{array}$ & $\dot{.}$ & $\dot{.}$ & $\cdot$ \\
\hline 13 & Kunst- en vormgevende beroepen & 7 & . & 6 \\
\hline 1321 & Fotografen, filmers, vormgevers, etaleurs & . & . & . \\
\hline 1331 & Beeldende en uitvoerende kunstenaars & . & . & . \\
\hline 2 & AGRARISCHE BEROEPEN & 3 & 3 & 3 \\
\hline 20 & Agrarische beroepen & 3 & 3 & 3 \\
\hline 2011 & $\begin{array}{l}\text { Uitvoerend agrarisch personeel, } \\
\text { bosarbeiders }\end{array}$ & 4 & . & 4 \\
\hline 2012 & Zelfstandige agrariërs, boswachters & 2 & . & 2 \\
\hline 2031 & Landbouwkundige vakspecialisten & . & $\cdot$ & $\cdot$ \\
\hline 3 & $\begin{array}{l}\text { TECHNISCHE, AMBACHTS- EN } \\
\text { INDUSTRIEBEROEPEN }\end{array}$ & 8 & 6 & 8 \\
\hline 30 & $\begin{array}{l}\text { Technische, ambachts- en industrie- } \\
\text { beroepen }\end{array}$ & 9 & 7 & 9 \\
\hline 3011 & Heftruck- en hefvorkchauffeurs & 9 & . & 9 \\
\hline 3012 & Machinisten bouw en industrie & 11 & . & 13 \\
\hline 3021 & $\begin{array}{l}\text { Directeuren, bedrijfsleiders, } \\
\text { leidinggevenden industrie }\end{array}$ & 8 & . & 8 \\
\hline 3022 & $\begin{array}{l}\text { Technische en medische } \\
\text { vertegenwoordigers }\end{array}$ & & . & \\
\hline 3023 & Technische tekenaars & 10 & . & 11 \\
\hline 3024 & Technische analisten, amanuenses & 9 & . & 8 \\
\hline 3031 & $\begin{array}{l}\text { Bèta-onderzoekers, technische } \\
\text { vakspecialisten }\end{array}$ & 8 & . & 8 \\
\hline $\begin{array}{l}31 \\
3111 \\
3112\end{array}$ & $\begin{array}{l}\text { Voedings- en genotmiddelenberoepen } \\
\text { Voedingsmiddelenbereiders } \\
\text { (Zelfstandige) bakkers e.a. } \\
\text { (industrieel) bakkerijpersoneel }\end{array}$ & $\begin{array}{l}5 \\
5\end{array}$ & $\dot{.}$ & $\begin{array}{l}5 \\
6\end{array}$ \\
\hline 32 & Textielberoepen & . & . & 4 \\
\hline $\begin{array}{l}3211 \\
3212\end{array}$ & $\begin{array}{l}\text { Produktiepersoneel textielindustrie } \\
\text { Stoffeerders, schoen- e.a. lederwarenmakers }\end{array}$ & . & . & $\cdot$ \\
\hline 3212 & Stoffeerders, schoen- e.a. lederwarenmakers & - & $\cdot$ & . \\
\hline
\end{tabular}


3213 Kleding-e.a. textiel- en bontproduktenmakers

33 Hout- en papierberoepen

3311 Houtzagers, hout(waren)papier- en kartonmakers

3312 Houtbewerkers, timmerlieden

34 Grafische beroepen

3411 Drukkers, boekbinders, fotolaboranten

3611 Delfstoffen(be)werkers, metaalvervaardigers

3612 Machinale metaalbewerkers

3613 Lassers, constructiewerkers, edelmetaalsmeden

3614 Machinebank- en plaatwerkers, gereedschaps- en modelmakers

3615 Onderhoudsmonteurs, fietsen- en instrumentmakers

3621 Auto-, motor- en bromfietsmonteurs

3622 Middelbare (scheeps)werktuigkundigen e.a. metaalkundigen

3631 Hogere werktuigkundigen

37 Elektrotechnische beroepen

3711 Samenstellers elektrotechnische produkten, kwaliteitscontroleurs

3712 Lijnwerkers, kabelmonteurs en -lassers

3721 Elektriciens, elektro- en telecom(onderhouds)monteurs

3722 Middelbare elektrotechnici

3731 Hogere elektrotechnici

38 Bouwmaterialen-, glas-en aardewerkberoepen

3811 Produktiepersoneel bouwmaterialen-, glas- en aardewerkindustrie

39 Bouw-en installatieberoepen

3911 Metselaars, tegelzetters, straatmakers, stukadoors

3912 Betonwerkers, dakdekkers, isoleerders, glaszetters

3913 Huis-, scheeps- en constructieschilders

3914 Loodgieters, sanitair-installateurs en -reparateurs

3915 Overige bouwvaklieden, (spoor)weg- en reinigingswerkers

3921 Bouwkundige technici, opzichters, werkvoorbereiders

3931 Architecten, geodeten e.a. hogere bouwkundigen

41 Maritieme e.a. waterwegtransportberoepen

4111 Vissers, vis- en schaaldierkwekers, jagers e.d. 
4112 Matrozen e.a. scheepsdek-en machinekamerpersoneel

4121 Scheepsofficieren, loodsen. walinspecteurs

42 Rail- en wegtransportberoepen

e.a. transportmiddelenbestuurders

43 Lucht-en overige transportberoepen

4321 Vliegers, boordwerktuigkundigen, transportdienstleiders

50 Medische en paramedische beroepen

5021 Gediplomeerde verpleegkundigen, verloskundigen

5022 Leerling-verpleegkundigen, zieken- en kraamverzorgenden

5023 Dokters-, tandarts- en dierenartsassistenten

5024 Apothekersassistenten, opticiens, orthoptisten

5025 EEG-laboranten, keurmeesters, diëtisten, logopedisten, pedicuren

5031 Fysio-, arbeids- e.a. bewegingstherapeuten

5032 Radiologische, medische en biologische laboranten

5033 Geneeskundigen, medische adviseurs, apothekers

5034 Diergeneeskundigen, veterinaire geneeskundigen

5035 Tandheelkundigen en tandheelkundige specialisten

\section{ECONOMISCH-ADMINISTRATIEVE} BEROEPEN

$\begin{array}{rrr}9 & 9 & 9 \\ 9 & 11 & 10 \\ 9 & 11 & 10 \\ 9 & 9 & 9 \\ 8 & 9 & 7 \\ 11 & \cdot & 12 \\ \cdot & \cdot & 9 \\ 9 & 9 & 10 \\ 9 & \cdot & 9 \\ 9 & 9 & 9 \\ . & 8 & 9 \\ 9 & 8 & 8 \\ 10 & 8 & 9 \\ 8 & 8 & 9 \\ 8 & 8 & 9 \\ 7 & & 9 \\ 10 & & 9\end{array}$

60 Economisch-administratieve beroepen

6031 Hogere leidinggevenden

61 Administratieve beroepen

6111 Postdistributiepersoneel

6112 Datatypisten, computeroperators

6121 Administratief leidinggevenden

6122 Secretaressen, typisten

6123 Bibliotheekassistenten

6124 Boekhoudkundige, belasting-, loketen bankemployees

6125 Commercieel-administratieve employees

6126 Telefonisten, balie-employees, enquêteurs e.d.

6131 Systeemanalisten, -programmeurs en -beheerders

6132 Accountants, economen e.a. economische specialisten

6221 Winkeliers e.a. detail- en groothandelaren

6222 In-/verkoopchefs, handels-en verzekeringsagenten, makelaars e.d. 
63 Bestuurlijke en juridische beroepen

6331 Leden en leidinggevenden openbaar bestuur, beleidsambtenaren

6332 Juristen

7 SOCIAAL-CULTURELE BEROEPEN

70 Sociaal-culturele beroepen

7021 Auteurs, journalisten, nieuwslezers, presentatoren

7031 Bibliothecarissen, archivarissen, conservatoren

7032 Personeels- en beroepenspecialisten, arbeidsbemiddelaars

7033 Maatschappelijk werkers, reclasseringsambtenaren

7034 Sociale wetenschapsbeoefenaren

7035 Overige sociaal-culturele en commerciële vakspecialisten

8 VERZORGENDE EN DIENSTVERLENENDE BEROEPEN

81 Horecaberoepen

8111 Koks, kelners e.a. keuken- en serveerpersoneel

8121 Houders en leidinggevenden horeca- en recreatiebedrijven

82 Verzorgende beroepen

8211 Portiers, schoonmaak- e.a. lager dienstverlenend personeel

8212 Kinder-, gezins-, bejaardenverzorgenden e.a. verzorgend personeel

8221 Kappers, schoonheidsspecialisten

9 OPENBARE ORDE- EN VEILIGHEIDSBEROEPEN

91 Politie-, brandweer-en bewakingsberoepen

9121 Politie-, brandweer- en bewakingspersoneel

92 Militaire beroepen

9221 Beroepsmilitairen

Totaal (incl. beroep onbekend)

. = minder dan 2.000 werkenden 
Tabel C.6. Percentage vrouwen naar beroepsklasse in de regio Rijnmond en in geheel Nederland, gemiddelde 19891991

ROA- beroepsklasse
$\begin{aligned} & \text { Rijnmond } \\ & \text { code }\end{aligned}$

0 PEDAGOGISCHE BEROEPEN

01 Onderwijs(kundige) beroepen $\quad 51$

0131 Leerkrachten basis- en speciaal onderwijs $\quad 75$

0132 Docenten voortgezet en hoger onderwijs $\quad 36 \quad 34$

0133 Schoolhoofden e.a. onderwijskundige beroepen $\quad 26$

02 Sport(instructieve) beroepen 42

0221 Sportinstructeurs, officials, beroepssportlieden $\quad 42$

1 CULTURELE BEROEPEN 40

11 Taal- en letterkundige beroepen 67

1131 Taal- en letterkundigen, vertalers, tolken $\quad 67$

12 Theologische beroepen

1231 Pastorale beroepen

13 Kunst- en vormgevende beroepen

1321 Fotografen, filmers, vormgevers, etaleurs

1331 Beeldende en uitvoerende kunstenaars $\quad .46$

2 AGRARISCHE BEROEPEN $\quad 25 \quad 21$

20 Agrarische beroepen $\quad 25 \quad 21$

2011 Uitvoerend agrarisch personeel, bosarbeiders $\quad 25$

2012 Zelfstandige agrariërs, boswachters $\quad$. 9

2031 Landbouwkundige vakspecialisten

3 TECHNISCHE, AMBACHTS- EN INDUSTRIEBEROEPEN

30 Technische, ambachts-en industrieberoepen

3011 Heftruck- en hefvorkchauffeurs

3012 Machinisten bouw en industrie

3021 Directeuren, bedrijfsleiders, leidinggevenden industrie $\quad$. . $^{\circ}$

3022 Technische en medische vertegenwoordigers . . .

3023 Technische tekenaars $\quad . \quad 26$

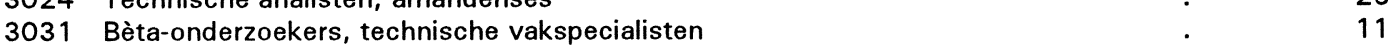

31 Voedings- en genotmiddelenberoepen $\quad$. 14

3111 Voedingsmiddelenbereiders $\quad 17$

3112 (Zelfstandige) bakkers e.a. (industrieel) bakkerijpersoneel 10

32 Textielberoepen

3211 Produktiepersoneel textielindustrie

3212 Stoffeerders, schoen- e.a. lederwarenmakers 28

3213 Kleding- e.a. textiel- en bontproduktenmakers $\quad .83$

33 Hout- en papierberoepen 2 . 2

3311 Houtzagers, hout(waren)-, papier- en kartonmakers $\quad$.

3312 Houtbewerkers, timmerlieden

34 Grafische beroepen $\quad$. 22

3411 Drukkers, boekbinders, fotolaboranten $\quad$. 22

35 Chemische beroepen $\quad$. 7

3511 Produktiepersoneel chemische industrie $\quad 7$

36 Metaalberoepen 3

3611 Delfstoffen(be)werkers, metaalvervaardigers

3612 Machinale metaalbewerkers $\quad$. 11 
3613 Lassers, constructiewerkers, edelmetaalsmeden

3614 Machinebank- en plaatwerkers, gereedschaps- en modelmakers

3615 Onderhoudsmonteurs, fietsen- en instrumentmakers

3621 Auto-, motor- en bromfietsmonteurs

3622 Middelbare (scheeps)werktuigkundigen e.a. metaalkundigen

3631 Hogere werktuigkundigen

37 Elektrotechnische beroepen

3711 Samenstellers elektrotechnische produkten, kwaliteitscontroleurs

3712 Lijnwerkers, kabelmonteurs en -lassers

3721 Elektriciens, elektro- en telecom(onderhouds)monteurs

3722 Middelbare elektrotechnici

3731 Hogere elektrotechnici

38 Bouwmaterialen-, glas-en aardewerkberoepen

3811 Produktiepersoneel bouwmaterialen-, glas- en aardewerkindustrie

39 Bouw-en installatieberoepen

3911 Metselaars, tegelzetters, straatmakers, stukadoors

3912 Betonwerkers, dakdekkers, isoleerders, glaszetters

3913 Huis-, scheeps- en constructieschilders

3914 Loodgieters, sanitair-installateurs en -reparateurs

3915 Overige bouwvaklieden, (spoor)weg- en reinigingswerkers

3921 Bouwkundige technici, opzichters, werkvoorbereiders

3931 Architecten, geodeten e.a. hogere bouwkundigen

4 TRANSPORTBEROEPEN

40 Transportberoepen

4011 Laders, lossers, vul- en inpak(machine)bedienden

41 Maritieme e.a. Waterwegtransportberoepen

4111 Vissers, vis- en schaaldierkwekers, jagers e.d.

4112 Matrozen e.a. scheepsdek- en machinekamerpersoneel

4121 Scheepsofficieren, loodsen, walinspecteurs

42 Rail- en wegtransportberoepen

4211 Conducteurs, chauffeurs e.a. transportmiddelenbestuurders

43 Lucht-en overige transportberoepen

4321 Vliegers, boordwerktuigkundigen, transportdienstleiders

5 MEDISCHE EN PARAMEDISCHE BEROEPEN

50 Medische en paramedische beroepen

5021 Gediplomeerde verpleegkundigen, verloskundigen

5022 Leerling-verpleegkundigen, zieken- en kraamverzorgenden

5023 Dokters-, tandarts- en dierenartsassistenten

5024 Apothekersassistenten, opticiens, orthoptisten

5025 EEG-laboranten, keurmeesters, diëtisten, logopedisten, pedicuren

5031 Fysio-, arbeids- e.a. bewegingstherapeuten

5032 Radiologische, medische en biologische laboranten

5033 Geneeskundigen, medische adviseurs, apothekers

5034 Diergeneeskundigen, veterinaire geneeskundigen

5035 Tandheelkundigen en tandheelkundige specialisten

6 ECONOMISCH-ADMINISTRATIEVE BEROEPEN

60 Economisch-administratieve beroepen

6122 Secretaressen, typisten

6123 Bibliotheekassistenten

6124 Boekhoudkundige, belasting-, loket- en bankemployees

6125 Commercieel-administratieve employees

6126 Telefonisten, balie-employees, enquêteurs e.d.

6131 Systeemanalisten, -programmeurs en -beheerders 
6132 Accountants, economen e.a. economische specialisten

62 Commerciële beroepen

6211 Winkel-, straat- en marktverkopers, demonstrateurs

65

6221 Winkeliers e.a. detail- en groothandelaren

6222 In-/verkoopchefs, handels- en verzekeringsagenten, makelaars e.d

63 Bestuurlijke en juridische beroepen

6331 Leden en leidinggevenden openbaar bestuur, beleidsambtenaren

7 SOCIAAL-CULTURELE BEROEPEN

70 Sociaal-culturele beroepen

7021 Auteurs, journalisten, nieuwslezers, presentatoren

7031 Bibliothecarissen, archivarissen, conservatoren

7032 Personeels- en beroepenspecialisten, arbeidsbemiddelaars

7033 Maatschappelijk werkers, reclasseringsambtenaren

7034 Sociale wetenschapsbeoefenaren

7035 Overige sociaal-culturele en commerciële vakspecialisten

81 Horecaberoepen

8111 Koks, kelners e.a. keuken- en serveerpersoneel

8121 Houders en leidinggevenden horeca- en recreatiebedrijven

82 Verzorgende beroepen

8211 Portiers, schoonmaak- e.a. lager dienstverlenend personeel

8212 Kinder-, gezins-, bejaardenverzorgenden e.a. verzorgend personeel

8221 Kappers, schoonheidsspecialisten

9121 Politie-, brandweer- en bewakingspersoneel

$92 \quad$ Militaire beroepen

9221 Beroepsmilitairen 
Tabel C.7. Aantal werkenden naar opleidingstype en geslacht in de regio Rijnmond en in geheel Nederland, gemiddelde 1990-1991

\begin{tabular}{|c|c|c|c|c|c|c|c|}
\hline \multirow{2}{*}{$\begin{array}{l}\text { sol- } \\
\text { code }\end{array}$} & \multirow[t]{2}{*}{ opleidingstype } & \multicolumn{3}{|c|}{ Rijnmond } & \multicolumn{3}{|c|}{ Nederland } \\
\hline & & mannen & vrouwen & totaal & mannen & vrouwen & totaal \\
\hline $0,1,2$ & BASISONDERWIJS & 37.000 & 15.000 & 52.000 & 423.000 & 174.000 & 597.000 \\
\hline $000,111,201$ & Basisonderwijs & 37.000 & 15.000 & 52.000 & 423.000 & 174.000 & 597.000 \\
\hline 3 & MAVO, LBO & 71.000 & 41.000 & 112.000 & 932.000 & \multicolumn{2}{|c|}{493.0001 .425 .000} \\
\hline \multirow[t]{2}{*}{301} & \multicolumn{2}{|l|}{ MAVO en onderbouw } & & & & & \\
\hline & HAVO/VWO & 15.000 & 17.000 & 32.000 & 206.000 & 190.000 & 396.000 \\
\hline $321-329$ & LBO Agrarisch & 4.000 & • & 4.000 & 89.000 & 7.000 & 96.000 \\
\hline $331-339$ & LBO Technisch & 37.000 & . & 40.000 & 493.000 & 25.000 & 518.000 \\
\hline $341-349$ & LBO Haven \& Vervoer & 5.000 & . & 6.000 & 36.000 & - & 37.000 \\
\hline \multirow[t]{2}{*}{$361-369$} & LBO Economisch- & \multirow[b]{2}{*}{5.000} & & & & & \\
\hline & Administratief & & 8.000 & 13.000 & 61.000 & 73.000 & 134.000 \\
\hline $381-389$ & LBO Verzorgend & - & 12.000 & 14.000 & 26.000 & 186.000 & 211.000 \\
\hline $391-394$ & \multicolumn{2}{|l|}{ LBO Beveiliging \& Bewaking } & $\cdot$ & • & 6.000 & • & 7.000 \\
\hline 4 & HAVONWO, MBO & 120.000 & 65.000 & 186.000 & 1.572 .000 & \multicolumn{2}{|c|}{867.0002 .439 .000} \\
\hline 401 & Bovenbouw HAVO/VWO & 13.000 & 11.000 & 25.000 & 152.000 & 115.000 & 267.000 \\
\hline $421-429$ & MBO Agrarisch & • & • & 3.000 & 109.000 & 12.000 & 121.000 \\
\hline 431 & MBO Technisch Laborator & rium $\quad$. & . & • & 9.000 & 5.000 & 13.000 \\
\hline $436-439$ & MBO Technisch & 49.000 & . & 51.000 & 635.000 & 36.000 & 671.000 \\
\hline $441-449$ & MBO Haven \& Vervoer & 9.000 & . & 9.000 & 39.000 & 4.000 & 44.000 \\
\hline 452 & MBO Medisch Laboratoriu & um . & . & • & 4.000 & 17.000 & 21.000 \\
\hline 451,454 & MBO Verpleging \& & & & & & & \\
\hline & Ziekenverzorging & . & 11.000 & 12.000 & 19.000 & 151.000 & 170.000 \\
\hline $453,461-464$ & MBO Economisch \& & & & & & & \\
\hline & Administratief & 28.000 & 22.000 & 51.000 & 402.000 & 265.000 & 667.000 \\
\hline 466 & MBO Bestuurlijk & 3.000 & . & 4.000 & 35.000 & 10.000 & 44.000 \\
\hline 471 & MBO Sociaal-Cultureel & • & . & . & 16.000 & 26.000 & 41.000 \\
\hline $481,484,486$ & MBO Verzorgend & . & 8.000 & 10.000 & 32.000 & 179.000 & 211.000 \\
\hline 483 & MBO Horeca \& Kappers & • & 3.000 & 4.000 & 22.000 & 25.000 & 47.000 \\
\hline $491-494$ & MBO Politie \& Defensie & 7.000 & $\cdot$ & 8.000 & 83.000 & 4.000 & 87.000 \\
\hline 5 & HBO & 41.000 & 30.000 & 71.000 & 515.000 & 355.000 & 871.000 \\
\hline 506 & HBO Onderwijs & 7.000 & 10.000 & 17.000 & 117.000 & 120.000 & 237.000 \\
\hline 511 & HBO Tolk \& Vertaler & • & • & • & $\cdot$ & 3.000 & 5.000 \\
\hline 516 & HBO Theologisch & . & - & . & 3.000 & • & 3.000 \\
\hline $521-529$ & HBO Agrarisch & . & - & . & 13.000 & • & 15.000 \\
\hline 531 & HBO Technisch Laborator & rium $\quad$. & . & 3.000 & 19.000 & 10.000 & 29.000 \\
\hline $536-539$ & HBO Technisch & 9.000 & . & 9.000 & 111.000 & 4.000 & 115.000 \\
\hline $541-549$ & HBO Vervoer & 7.000 & . & 7.000 & 26.000 & • & 26.000 \\
\hline 552 & HBO Medisch Laboratoriu & um . & . & 3.000 & 4.000 & 14.000 & 18.000 \\
\hline 551,554 & HBO Verpleging \& Param & ledisch & 4.000 & 5.000 & 21.000 & 54.000 & 75.000 \\
\hline 561 & $\begin{array}{l}\text { HBO Economisch- } \\
\text { Administratief }\end{array}$ & & & & & 73.000 & 166000 \\
\hline 562 & $\begin{array}{l}\text { Administratiet } \\
\text { HBO Technische Bedrijfsk }\end{array}$ & kunde & 1.000 & $\begin{array}{r}13.000 \\
.\end{array}$ & 10.000 & $\begin{array}{r}13.000 \\
.\end{array}$ & 10.000 \\
\hline 566 & HBO Bestuurlijk & . & . & . & 17.000 & 3.000 & 20.000 \\
\hline 571 & HBO Sociaal-Cultureel & 4.000 & 4.000 & 7.000 & 45.000 & 54.000 & 99.000 \\
\hline 583 & HBO Horeca & • & • & . & 3.000 & • & 4.000 \\
\hline 586 & HBO Kunst & . & . & . & 20.000 & 13.000 & 33.000 \\
\hline $591-594$ & HBO Politie \& Defensie & . & · & . & 9.000 & . & 9.000 \\
\hline 6 & Wo & 22.000 & 6.000 & 28.000 & 291.000 & 99.000 & 390.000 \\
\hline 606 & WO Onderwijs & - & - & . & 11.000 & 7.000 & 19.000 \\
\hline 611 & WO Humaniora & . & . & . & 18.000 & 15.000 & 33.000 \\
\hline 616 & WO Theologisch & . & . & . & 5.000 & • & 6.000 \\
\hline
\end{tabular}


-59-

\begin{tabular}{|c|c|c|c|c|c|c|c|}
\hline $621-629$ & WO Agrarisch & . & . & & 8.000 & & 10.000 \\
\hline 631 & WO Wis-/Natuurkunde & . & . & 3.000 & 33.000 & 6.000 & 39.000 \\
\hline $636-639$ & WO Technisch & 4.000 & . & 4.000 & 51.000 & 3.000 & 54.000 \\
\hline \multirow[t]{2}{*}{651} & WO Dier-/Genees-/ & & & & & & \\
\hline & Tandheelkunde & 3.000 & . & 4.000 & 35.000 & 12.000 & 47.000 \\
\hline 652 & WO Farmacie & . & . & . & 4.000 & - & 5.000 \\
\hline \multirow[t]{2}{*}{$661-662$} & WO Econom(etr)ie \& & & & & & & \\
\hline & Bedrijfskunde & 4.000 & - & 4.000 & 43.000 & 3.000 & 47.000 \\
\hline \multirow[t]{2}{*}{666} & WO Rechten \& & & & & & & \\
\hline & Bestuurskunde & 3.000 & - & 4.000 & 34.000 & 13.000 & 48.000 \\
\hline 671 & WO Sociaal-Cultureel & 3.000 & - & 4.000 & 41.000 & 31.000 & 72.000 \\
\hline \multirow[t]{2}{*}{686} & WO Kunst & ${ }^{\circ}$ & - & . & . & 3.000 & 5.000 \\
\hline & Totaal & 293.000 & 156.000 & 449.000 & 3.746 .000 & 994.000 & 740.000 \\
\hline
\end{tabular}

Bron: CBS/ROA 
Tabel C.8. Percentage vrouwen naar opleidingstype in de regio Rijnmond en in geheel Nederland, gemiddelde 19901991

\begin{tabular}{llc}
\hline $\begin{array}{l}\text { SOl- } \\
\text { code }\end{array}$ & opleidingstype & Rijnmond \\
& vrouwen & mannen \\
\hline
\end{tabular}

\section{$0,1,2$ \\ 3 \\ 301 \\ $321-329$ \\ 331-339 \\ 341-349 \\ 361-369 \\ 381-389 \\ 391-394}

000, 111, 201

BASISONDERWIJS

4

401

421-429

431

436-439

441-449

452

451,454

$453,461-464$

466

471

$481,484,486$

483

491-494

5

506

511

516

521-529

531

536-539

541-549

552

551,554

561

562

566

571

583

586

591-594

6

\section{6}

611

616

621-629

631

636-639

651

652
Basisonderwijs

MAVO, LBO

MAVO en onderbouw HAVO/VWO

LBO Agrarisch

LBO Technisch

LBO Haven \& Vervoer

LBO Economisch-Administratief

LBO Verzorgend

LBO Beveiliging \& Bewaking

HAVO/VWO, MBO

Bovenbouw HAVO/VWO

MBO Agrarisch

MBO Technisch Laboratorium

MBO Technisch

MBO Haven \& Vervoer

MBO Medisch Laboratorium

MBO Verpleging \& Ziekenverzorging

MBO Economisch \& Administratief

MBO Bestuurlijk

MBO Sociaal-Cultureel

MBO Verzorgend

MBO Horeca \& Kappers

MBO Politie \& Defensie

HBO

HBO Onderwijs

HBO Tolk \& Vertaler

HBO Theologisch

HBO Agrarisch

HBO Technisch Laboratorium

HBO Technisch

HBO Vervoer

HBO Medisch Laboratorium

HBO Verpleging \& Paramedisch

HBO Economisch-Administratief

HBO Technische Bedrijfskunde

HBO Bestuurlijk

HBO Sociaal-Cultureel

HBO Horeca

HBO Kunst

HBO Politie \& Defensie

wo

Wo Onderwijs

WO Humaniora

WO Theologisch

WO Agrarisch

WO Wis-/Natuurkunde

WO Technisch

WO Dier-/Genees-/Tandheelkunde

WO Farmacie
9

9

9

9

9

8

8

8

7

9

8

4

16

10

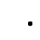

8

9

3

8

20

7

8

9

5

9

8

7

6

.

.

8

8
27

7

8

.

7

.

7

8

7

6

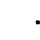

8

7 
$-61-$

661-662 WO Econom(etr)ie \& Bedrijfskunde

WO Rechten \& Bestuurskunde

WO Sociaal-Cultureel

9
9
7

671

WO Kunst

Totaal

. = minder dan 3.000 werkenden

Bron: CBS/ROA 
Tabel C.9. Percentage vrouwen naar opleidingstype in de regio Rijnmond en in geheel Nederland, gemiddelde 19901991

\begin{tabular}{|c|c|c|c|}
\hline $\begin{array}{l}\text { SOI- } \\
\text { code }\end{array}$ & opleidingstype & $\begin{array}{l}\text { Rijnmond } \\
\%\end{array}$ & $\begin{array}{c}\text { Nederland } \\
\%\end{array}$ \\
\hline $0,1,2$ & BASISONDERWIJS & 29 & 29 \\
\hline $000,111,201$ & Basisonderwijs & 29 & 29 \\
\hline 3 & MAVO, LBO & 37 & 35 \\
\hline 301 & MAVO en onderbouw HAVO/VWO & 53 & 48 \\
\hline $321-329$ & LBO Agrarisch & . & 7 \\
\hline $331-339$ & LBO Technisch & . & 5 \\
\hline $341-349$ & LBO Haven \& Vervoer & $\therefore$ & $\therefore$ \\
\hline $361-369$ & LBO Economisch-Administratief & 62 & 54 \\
\hline $381-389$ & LBO Verzorgend & 86 & 88 \\
\hline $391-394$ & LBO Beveiliging \& Bewaking & $\cdot$ & $\cdot$ \\
\hline 4 & HAVONWO, MBO & 35 & 36 \\
\hline 401 & Bovenbouw HAVO/VWO & 44 & 43 \\
\hline $421-429$ & MBO Agrarisch & . & 10 \\
\hline 431 & MBO Technisch Laboratorium & . & 38 \\
\hline $436-439$ & MBO Technisch & . & 5 \\
\hline $441-449$ & MBO Haven \& Vervoer & . & 9 \\
\hline 452 & MBO Medisch Laboratorium & . & 81 \\
\hline 451,454 & MBO Verpleging \& Ziekenverzorging & 92 & 89 \\
\hline $453,461-464$ & MBO Economisch \& Administratief & 43 & 40 \\
\hline 466 & MBO Bestuurlijk & • & 23 \\
\hline 471 & MBO Sociaal-Cultureel & $\cdot$ & 63 \\
\hline $481,484,486$ & MBO Verzorgend & 80 & 85 \\
\hline 483 & MBO Horeca \& Kappers & 75 & 53 \\
\hline $491-494$ & MBO Politie \& Defensie & · & 5 \\
\hline 5 & HBO & 42 & 41 \\
\hline 506 & HBO Onderwijs & 59 & 51 \\
\hline 511 & HBO Tolk \& Vertaler & · & 60 \\
\hline 516 & HBO Theologisch & . & . \\
\hline $521-529$ & HBO Agrarisch & . & . \\
\hline 531 & HBO Technisch Laboratorium & . & 34 \\
\hline $536-539$ & HBO Technisch & . & 3 \\
\hline $541-549$ & HBO Vervoer & . & . \\
\hline 552 & HBO Medisch Laboratorium & • & 78 \\
\hline 551,554 & HBO Verpleging \& Paramedisch & 80 & 72 \\
\hline 561 & HBO Economisch-Administratief & 54 & 44 \\
\hline 562 & HBO Technische Bedrijfskunde & . & $\cdot$ \\
\hline 566 & HBO Bestuurlijk & & 15 \\
\hline 571 & HBO Sociaal-Cultureel & 57 & 55 \\
\hline 583 & HBO Horeca & · & $\dot{0}$ \\
\hline 586 & HBO Kunst & . & 39 \\
\hline $591-594$ & HBO Politie \& Defensie & $\cdot$ & $\cdot$ \\
\hline 6 & wo & 21 & 25 \\
\hline 606 & WO Onderwijs & . & 37 \\
\hline 611 & WO Humaniora & . & 45 \\
\hline 616 & WO Theologisch & . & • \\
\hline $621-629$ & WO Agrarisch & . & . \\
\hline 631 & WO Wis-/Natuurkunde & . & 15 \\
\hline $636-639$ & WO Technisch & . & 6 \\
\hline 651 & WO Dier-/Genees-/Tandheelkunde & . & 26 \\
\hline 652 & WO Farmacie & . & . \\
\hline
\end{tabular}


$-63-$

661-662 WO Econom(etr)ie \& Bedrijfskunde

WO Rechten \& Bestuurskunde

WO Sociaal-Cultureel

6

666

671

WO Kunst

27

43

686

Totaal

. = minder dan 3.000 werkenden

Bron: CBS/ROA 
Tabel C.10. Aantal werkenden naar bedrijfssector en naar opleidingsniveau in de regio Rijnmond en in geheel Nederland, gemiddelde 1990-1991

\begin{tabular}{|c|c|c|c|c|c|c|c|c|c|c|}
\hline \multirow{2}{*}{\multicolumn{3}{|c|}{ Bedrijfssector }} & \multirow{3}{*}{1} & \multicolumn{7}{|c|}{ Opleidingsniveau } \\
\hline & & & & \multirow[t]{2}{*}{2} & \multirow{2}{*}{\multicolumn{2}{|c|}{3}} & \multirow[t]{2}{*}{4} & \multirow[t]{2}{*}{5} & \multirow[t]{2}{*}{6} & \multirow[t]{2}{*}{ totaal } \\
\hline \multicolumn{3}{|l|}{ Rijnmond } & & & & & & & & \\
\hline \multicolumn{3}{|c|}{ Land-, tuin- en bosbouw, visserij } & - & . & \multicolumn{2}{|c|}{3.000} & . & $\cdot$ & • & 7.000 \\
\hline \multirow{2}{*}{\multicolumn{3}{|c|}{$\begin{array}{l}\text { Chemische industrie } \\
\text { Metaalindustrie en openbare nutsbedrijven }\end{array}$}} & & . & \multicolumn{2}{|c|}{3.000} & . & 6.000 & 3.000 & 14.000 \\
\hline & & & 6.000 & . & \multicolumn{2}{|c|}{10.000} & . & 13.000 & 3.000 & 34.000 \\
\hline \multicolumn{3}{|c|}{ Delfstoffenwinning en aardolie industrie } & & . & \multirow{2}{*}{\multicolumn{2}{|c|}{4.000}} & . & 4.000 & & 7.000 \\
\hline \multicolumn{3}{|c|}{ Overige industrie } & 4.000 & . & & & . & 7.000 & 3.000 & 19.000 \\
\hline \multicolumn{3}{|c|}{ Bouwnijverheid en bouwinstallatiebedrijven } & 6.000 & . & \multicolumn{2}{|c|}{10.000} & . & 11.000 & . & 31.000 \\
\hline \multicolumn{3}{|c|}{ Groothandel en reparatiebedrijven } & 5.000 & 3.000 & \multicolumn{2}{|c|}{7.000} & 3.000 & 15.000 & 5.000 & 38.000 \\
\hline \multicolumn{3}{|c|}{ Detailhandel en horeca } & 7.000 & 5.000 & \multicolumn{2}{|c|}{9.000} & 3.000 & 14.000 & . & 40.000 \\
\hline \multicolumn{3}{|c|}{ Vervoer en communicatie } & 8.000 & 6.000 & \multicolumn{2}{|c|}{12.000} & 3.000 & 19.000 & 7.000 & 55.000 \\
\hline \multirow{2}{*}{\multicolumn{3}{|c|}{$\begin{array}{l}\text { Bank- en verzekeringswezen } \\
\text { Overige tertiaire dienstverlening }\end{array}$}} & . & 3.000 & & & 3.000 & 9.000 & 5.000 & 22.000 \\
\hline & & & . & 3.000 & & 000 & 4.000 & 13.000 & 16.000 & 41.000 \\
\hline Overheid e & ade & wijs & 3.000 & 3.000 & & .000 & . & 18.000 & 29.000 & 58.000 \\
\hline Overige $\mathrm{kv}$ & aire & dienstverlening & 9.000 & 4.000 & & 000 & 4.000 & 29.000 & 22.000 & 79.000 \\
\hline Totaal & & & 52.000 & 32.000 & & 000 & 25.000 & 161.000 & 99.000 & 449.000 \\
\hline Nederland & & & & & & & & & & \\
\hline Land-, tuin & bo & sbouw, visserij & 37.000 & 14.000 & 94 & 000 & 5.000 & 107.000 & 8.000 & 264.000 \\
\hline Chemische & lust & & 15.000 & 8.000 & & 000 & 5.000 & 52.000 & 29.000 & 135.000 \\
\hline Metaalind & e er & openbare nutsbedrijven 8 & 86.000 & 33.000 & 140 & 000 & 15.000 & 213.000 & 81.000 & 570.000 \\
\hline Delfstoffer & nin & en aardolie industrie & & & & & & 9.000 & 6.000 & 21.000 \\
\hline Overige in & & & 78.000 & 36.000 & 101 & 000 & 17.000 & 157.000 & 42.000 & 432.000 \\
\hline Bouwnijve & & bouwinstallatiebedrijven 6 & 65.000 & 15.000 & 134 & 000 & 5.000 & 163.000 & 18.000 & 400.000 \\
\hline Groothand & n re & paratiebedrijven 4 & 47.000 & 39.000 & & 000 & 25.000 & 191.000 & 58.000 & 445.000 \\
\hline Detailhand & $\mathrm{n} \mathrm{h}$ & reca & 75.000 & 65.000 & 131 & 000 & 33.000 & 240.000 & 28.000 & 574.000 \\
\hline Vervoer er & $\mathrm{mm}$ & unicatie & 54.000 & 35.000 & & .000 & 21.000 & 124.000 & 38.000 & 358.000 \\
\hline Bank- en V & ker & ingswezen & 6.000 & 24.000 & & .000 & 25.000 & 94.000 & 46.000 & 214.000 \\
\hline Overige te & re d & ienstverlening & 15.000 & 27.000 & & .000 & 35.000 & 124.000 & 162.000 & 395.000 \\
\hline Overheid e & nde & wijs & 32.000 & 44.000 & & .000 & 36.000 & 259.000 & 412.000 & 851.000 \\
\hline Overige $\mathrm{kv}$ & & dienstverlening & 78.000 & 53.000 & 105 & 000 & 41.000 & 426.000 & 324.000 & 1.028 .000 \\
\hline Totaal & & & 97.000 & 396.000 & 1.029 & 000 & 267.000 & 2.172 .000 & 1.261 .000 & 5.740 .000 \\
\hline Legenda: & $\begin{array}{l}1 \\
2 \\
3\end{array}$ & $\begin{array}{l}\text { Basisonderwijs } \\
\text { MAVO en onderbouw HA } \\
\text { Lager Beroepsonderwijs }\end{array}$ & AVo/VWo & & $\begin{array}{l}4 \\
5 \\
6\end{array}$ & $\begin{array}{l}\text { HAVC } \\
\text { Midd } \\
\text { Hoge }\end{array}$ & $\begin{array}{l}\text { P/VWo } \\
\text { elbaar Beroe } \\
\text { onderwijs }\end{array}$ & psonderwijs & & \\
\hline$=\operatorname{mind}$ & & OO werkenden & & & & & & & & \\
\hline
\end{tabular}

Bron: CBS/ROA 
Tabel C.11. Percentage vrouwen naar bedrijfssector en naar opleidingsniveau in de regio Rijnmond en in geheel Nederland, gemiddelde 1990-1991

\begin{tabular}{lrrrrrrrr}
\hline Bedrijfsector & 1 & 2 & 3 & 4 & 5 & 6 & Opleidingsniveau \\
& $\%$ & $\%$ & $\%$ & $\%$ & $\%$ & $\%$ & $\%$ & $\%$ \\
\hline
\end{tabular}

Rijnmond

Land-, tuin- en bosbouw, visserij

Chemische industrie

Metaalindustrie en openbare nutsbedrijven

Delfstoffenwinning en aardolie industrie

Overige industrie

Bouwnijverheid en bouwinstallatiebedrijven

Groothandel en reparatiebedrijven

Detailhandel en horeca

Vervoer en communicatie

Bank- en verzekeringswezen

Overige tertiaire dienstverlening

Overheid en onderwijs

Overige kwartaire dienstverlening

Totaal

.

Nederland

Land-, tuin- en bosbouw, visserij

Chemische industrie

Metaalindustrie en openbare nutsbedrijven

Delfstoffenwinning en aardolie industrie

Overige industrie

Bouwnijverheid en bouwinstallatiebedrijven

Groothandel en reparatiebedrijven

Detailhandel en horeca

Vervoer en communicatie

Bank- en verzekeringswezen

Overige tertiaire dienstverlening

Overheid en onderwijs

Overige kwartaire dienstverlening

Totaal
14

26

19

7

50

47

29

Legenda:

\section{Basisonderwijs}

MAVO en onderbouw HAVO/VWO

Lager Beroepsonderwijs

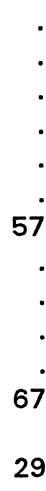

57

(

$+70^{\circ}$

$100 \quad 73$

$53 \quad 30$

44

34

. = minder dan 3.000 werkenden

$\begin{array}{rrrrrc}43 & 26 & 60 & 19 & 38 & 25 \\ 38 & 15 & . & 15 & 17 & 17 \\ 27 & 12 & 33 & 11 & 12 & 14 \\ 36 & 28 & 35 & . & 31 & . \\ 20 & 3 & . & 22 & . & 67 \\ 36 & 18 & 32 & 6 & 28 & 22 \\ 65 & 64 & 48 & 19 & 46 & 53 \\ 29 & 10 & 38 & 45 & 32 & 18 \\ 54 & 53 & 44 & 39 & 28 & 41 \\ 59 & 41 & 40 & 37 & 25 & 34 \\ 43 & 27 & 36 & 26 & 37 & 33 \\ 75 & 69 & 66 & 78 & 53 & 67 \\ 48 & 29 & 43 & 35 & 36 & 35\end{array}$

Bron: CBS/ROA 
Tabel C.12. Percentage werkenden naar opleidingsniveau per bedrijfssector in de regio Rijnmond en in geheel Nederland, gemiddelde 1990-1991 (rijpercentages)

\begin{tabular}{|c|c|c|c|c|c|c|c|}
\hline \multirow{3}{*}{ Bedrijfssector } & \multicolumn{7}{|c|}{ Opleidingsniveau } \\
\hline & 1 & 2 & 3 & 4 & 5 & 6 & totaal \\
\hline & $\%$ & $\%$ & $\%$ & $\%$ & $\%$ & $\%$ & aantal \\
\hline
\end{tabular}

Rijnmond

Land-, tuin- en bosbouw, visserij

Chemische industrie

Metaalindustrie en openbare nutsbedrijven $\quad 18 \quad$. 29

Delfstoffenwinning en aardolie industrie

Overige industrie

Bouwnijverheid en bouwinstallatiebedrijven

Groothandel en reparatiebedrijven

Detailhandel en horeca

Vervoer en communicatie

Bank- en verzekeringswezen

Overige tertiaire dienstverlening

Overheid en onderwijs

Overige kwartaire dienstverlening

Totaal

Nederland

Land-, tuin- en bosbouw, visserij

Chemische industrie

Metaalindustrie en openbare nutsbedrijven

Delfstoffenwinning en aardolie industrie

Overige industrie

Bouwnijverheid en bouwinstallatiebedrijven

Groothandel en reparatiebedrijven

Detailhandel en horeca

Vervoer en communicatie

Bank- en verzekeringswezen

Overige tertiaire dienstverlening

Overheid en onderwijs

Overige kwartaire dienstverlening

Totaal

$\begin{array}{rrr}14 & 5 & 3 \\ 11 & 6 & 19 \\ 15 & 6 & 2 \\ . & . & \\ 18 & 8 & 23 \\ 16 & 4 & 34 \\ 11 & 9 & 19 \\ 13 & 11 & 23 \\ 15 & 10 & 24 \\ 3 & 11 & \\ 4 & 7 & \\ 4 & 5 & \\ 8 & 5 & 10\end{array}$

$10 \quad 7$
7.000

4.000

34.000

7.000

19.000

31.000

38.000

40.000

55.000

22.000

41.000

58.000

79.000

449.000

Legenda: 1 Basisonderwijs

2 MAVO en onderbouw HAVO/VWO

3 Lager Beroepsonderwijs 
Tabel C.13. Percentage werkenden naar bedrijfssector per opleidingsniveau in de regio Rijnmond en in geheel Nederland, gemiddelde 1990-1991 (kolompercentages)

\begin{tabular}{|c|c|c|c|c|c|c|c|}
\hline \multirow[t]{3}{*}{ Bedrijfssector } & \multicolumn{7}{|c|}{ Opleidingsniveau } \\
\hline & 1 & 2 & 3 & 4 & 5 & 6 & totaal \\
\hline & $\%$ & $\%$ & $\%$ & $\%$ & $\%$ & $\%$ & $\%$ \\
\hline
\end{tabular}

Rijnmond

Land-, tuin- en bosbouw, visserij Chemische industrie

Metaalindustrie en openbare nutsbedrijven Delfstoffenwinning en aardolie industrie

Overige industrie

Bouwnijverheid en bouwinstallatiebedrijven

Groothandel en reparatiebedrijven

Detailhandel en horeca

Vervoer en communicatie

Bank- en verzekeringswezen

Overige tertiaire dienstverlening

Overheid en onderwijs

Overige kwartaire dienstverlening

Totaal

$\begin{array}{rrrrrrr}. & . & 4 & . & . & 2 & 2 \\ 12 & . & 4 & . & 4 & 3 & 3 \\ . & . & 13 & . & 8 & 8 & 8 \\ 8 & . & . & . & 2 & 2 & 2 \\ 12 & . & 13 & . & 4 & 4 & 4 \\ 10 & 9 & 9 & 12 & 7 & 7 & 7 \\ 13 & 16 & 11 & 12 & 9 & 8 & 8 \\ 15 & 19 & 15 & 12 & 12 & 12 & 9 \\ . & 9 & . & 12 & 6 & 5 & 12 \\ . & 9 & 5 & 16 & 8 & 16 & 5 \\ 6 & 9 & 5 & . & 11 & 29 & 9 \\ 17 & 13 & 14 & 16 & 18 & 22 & 13 \\ 100 & 100 & 100 & 100 & 100 & 100 & 18\end{array}$

Nederland

Land-, tuin- en bosbouw, visserij

Chemische industrie

Metaalindustrie en openbare nutsbedrijven

Delfstoffenwinning en aardolie industrie

Overige industrie

Bouwnijverheid en bouwinstallatiebedrijven

Groothandel en reparatiebedrijven

Detailhandel en horeca

Vervoer en communicatie

Bank- en verzekeringswezen

Overige tertiaire dienstverlening

Overheid en onderwijs

Overige kwartaire dienstverlening

$\begin{array}{rrr}6 & 4 & \\ 3 & 2 & \\ 14 & 8 & 14 \\ . & . & \\ 13 & 9 & 10 \\ 11 & 4 & 13 \\ 8 & 10 & \\ 13 & 16 & 13 \\ 9 & 9 & \\ 1 & 6 & \\ 3 & 7 & \\ 5 & 11 & \\ 13 & 13 & 13 \\ & & \end{array}$

Totaal

$100 \quad 100$

100

100

8

Legenda:

Basisonderwijs

MAVO en onderbouw HAVO/VWO

Lager Beroepsonderwijs

4 HAVO/VWO

5 Middelbaar Beroepsonderwijs

6 Hoger onderwijs

. = minder dan 3.000 werkenden

Bron: $\mathrm{CBS} / \mathrm{ROA}$ 


\begin{tabular}{|c|c|c|c|c|c|c|c|c|}
\hline \multirow{2}{*}{\multicolumn{2}{|c|}{$000^{\circ} 099^{\circ} \mathrm{S}^{\circ} 00 \mathrm{~S}^{\circ} \mathrm{L} L Z$}} & \multirow{3}{*}{$\begin{array}{l}009^{\circ} \varepsilon\llcorner\iota \\
000^{\circ} 0 乙\end{array}$} & \multirow{2}{*}{\multicolumn{2}{|c|}{ OOS'tLて's OOS'てtヤ }} & \multirow{3}{*}{ 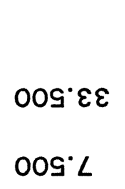 } & \multirow{3}{*}{$\begin{array}{l}\text { OOS'OL } \\
000 \%\end{array}$} & \multirow{3}{*}{$\begin{array}{l}00 S^{\circ} 86 \varepsilon \\
00 S^{\circ} 0 L\end{array}$} & \multirow{3}{*}{ 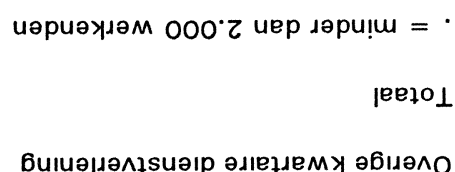 } \\
\hline & & & & & & & & \\
\hline $009^{\circ} 9001$ & .000: 29 & & $000^{\circ} \varepsilon \varepsilon 6$ & $000^{\circ} 08^{2}$ & & & & \\
\hline 000.698 & $009 \cdot 9 \varepsilon$ & oOs`てl & 000.018 & $009^{\circ} 99$ & $00 \mathcal{S}^{\circ} \varepsilon$ & $\cdot$ & 000.29 & s!!Mдәрuо иә р!әчдә^о \\
\hline $000 \cdot\llcorner 8 \varepsilon$ & $000 \cdot 91$ & $000 \cdot 6$ & $000 \cdot 99 \varepsilon$ & $000^{\circ} 8 \varepsilon$ & $000 \cdot 2$ & $\cdot$ & $000^{\circ} \mathrm{s \varepsilon}$ & 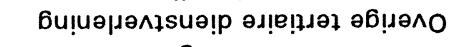 \\
\hline OOS'OlZ & oos'lı & $000^{\circ} t$ & $00 s^{\circ}+6 L$ & $000 \bullet 乙$ & $\cdot$ & $\cdot$ & $00 S^{\circ} 6 \mathrm{l}$ & 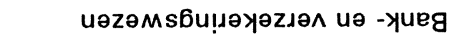 \\
\hline $000^{\circ} \downarrow \varsigma \varepsilon$ & OOS๋ヤL & $000 \cdot 8$ & 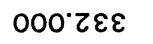 & $000^{\circ} 99$ & $00 s^{\prime} Z$ & $\cdot$ & $000^{\circ} 19$ & ә!ฺеอ! \\
\hline OOS't9s & $000 \cdot 62$ & $\operatorname{oog}^{\circ} \iota \iota$ & $000^{\circ} \triangleright 29$ & $000 \cdot 1 t$ & $000^{\circ} \varepsilon$ & $\cdot$ & $00 \mathcal{S}^{\prime} 9 \varepsilon$ & еоәдоч иә рәриечा!еґә \\
\hline 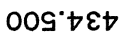 & oOs.9l & $000 \cdot 8$ & OOOOLt & $00 S^{\cdot} 9 \varepsilon$ & $000 \cdot 2$ & $\cdot$ & OOS' $\varepsilon \varepsilon$ & 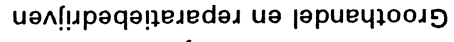 \\
\hline $000^{\circ} \triangleright 6 \varepsilon$ & OOS $^{\circ} \mathrm{L}$ & oos's & $000 \bullet\llcorner 8 \varepsilon$ & $000^{\circ} 0 \varepsilon$ & $\cdot$ & $\cdot$ & $000 \cdot 82$ & 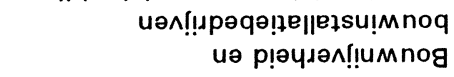 \\
\hline o০s'8Zt & $000 \cdot 62$ & $000^{\circ} \mathrm{Ol}$ & $000 \cdot 68 \varepsilon$ & $000 \cdot 6 l$ & oos' & $\cdot$ & 000.91 & 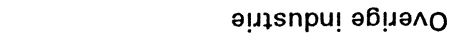 \\
\hline $000: 2 Z$ & $\cdot$ & $\cdot$ & $00 s^{\prime} 6 l$ & $000^{\circ} \mathrm{L}$ & $\cdot$ & $\cdot$ & $\operatorname{oos}^{\circ} 9$ & ә!ฺłsnpu! ә!ןордеe \\
\hline $000 . \varepsilon 99$ & $009^{\circ} 6 \varepsilon$ & oOs'9 L & $000^{\circ} \angle O S$ & o०s' $\varepsilon \varepsilon$ & $000^{\circ} t$ & $\cdot$ & oos' 82 & 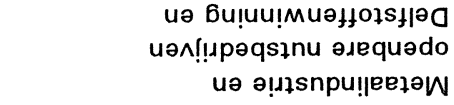 \\
\hline $000^{\circ} \angle \varepsilon l$ & $009^{\circ} 6$ & o०9't & OOS'てて। & $000^{\circ} \bullet L$ & $\cdot$ & $\cdot$ & 000 て & ә!ฺsnpu! әчэฺ!นәчว \\
\hline oog'l9Z & oos's & $\cdot$ & OOS'†s乙 & oos'9 & $\cdot$ & $\cdot$ & oos's & [!ress!n 'Mnoqsoq uә -u!̣ı '-pue \\
\hline jeejol & $\begin{array}{l}\text { ๑-ๆә!น } \\
\text { 6!ฺә^о }\end{array}$ & $\begin{array}{l}\text { פコ } \\
\text { 6!ฺә^о } \\
\text { pue|ләрәN }\end{array}$ & $\begin{array}{l}\text { pue| } \\
\text {-дәрәN }\end{array}$ & jeejol & 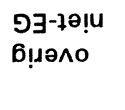 & $\begin{array}{l}9 \exists \\
\text { 6!ฺә^o } \\
\text { puouu!!y }\end{array}$ & $\begin{array}{l}\text { pue| } \\
\text {-גәрәN }\end{array}$ & 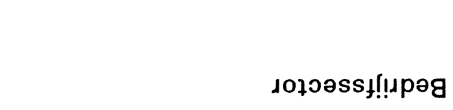 \\
\hline
\end{tabular}

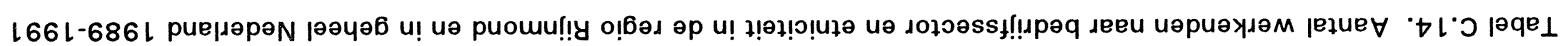


$\forall 0 y / S 80$ :uodg

\begin{tabular}{|c|c|c|c|c|c|c|c|c|c|}
\hline & & & & & & & & иәриәудәм $000^{\circ} \varepsilon$ uep & pu!us $=\cdot$ \\
\hline $000^{\circ} 0 t \angle L^{\circ} G$ & $000^{\circ} 082$ & $0002 \downarrow$ & $000^{\circ} \angle t \varepsilon^{\circ} \subseteq$ & $000 \cdot 6 t t$ & $000^{\circ} \succsim \varepsilon$ & $000 \% 6$ & $000.90 t$ & ןęo_ & \\
\hline $000^{\circ} 06 \varepsilon$ & $000^{\star} \pitchfork \tau$ & $000^{\circ} \downarrow l$ & $0000^{\circ}$ Zפ & 00082 & $\cdot$ & $\cdot$ & $000^{\circ} 92$ & $O M$ & 9 \\
\hline $000^{\circ} l \angle 8$ & $000^{\circ} 9 \varepsilon$ & $000^{\circ} \mathrm{gl}$ & $000 \cdot 618$ & $000 \cdot 1 L$ & $000^{\circ} \mathrm{s}$ & $\cdot$ & $000 \div 9$ & $\mathrm{OQH}$ & $\mathbf{S}$ \\
\hline $000^{\circ} Z \angle l^{\circ} Z$ & $000: 29$ & $000^{\circ} \iota \varepsilon$ & $000^{\circ} 6 \angle 0^{\circ} Z$ & $000 \cdot 19 l$ & $000^{\circ} \mathrm{L}$ & $\cdot$ & 000 ISL & ogw & $66 t-90 t$ \\
\hline $000<2$ & $000^{\circ} 81$ & $000^{\circ} 0 \mathrm{l}$ & $000 \cdot 6 \varepsilon 乙$ & $000 \cdot 92$ & & $\cdot$ & $000: 27$ & $O M \wedge / O \wedge \forall H$ & $10 t$ \\
\hline 000.6201 & $000^{\circ} \varepsilon t$ & $000 \cdot 9 l$ & $000 \cdot 1<6$ & $000 \cdot 08$ & $000^{\circ} \mathrm{L}$ & - & $000 \% L$ & 08า & $66 \varepsilon-90 \varepsilon$ \\
\hline $000 \cdot 96 \varepsilon$ & $000^{\circ} \angle Z$ & $000 \% 6$ & $000^{\circ} 09 \varepsilon$ & $000 \_\varepsilon$ & $000^{\circ} \varepsilon$ & $\cdot$ & 00062 & 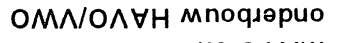 & \\
\hline $000^{\circ} \angle 69$ & 00089 & $000 \cdot 9 l$ & $000^{\circ} \varepsilon L$ & $000 \% 29$ & $000 \cdot 6$ & $\cdot$ & $000 \cdot t$ & $\begin{array}{r}\text { uә } 0 \wedge \forall W \\
\text { s!!Mдәрuos!seg }\end{array}$ & $\begin{aligned} & \begin{array}{l}l 0 \varepsilon \\
\tau^{\prime} \iota^{\prime} 0\end{array}\end{aligned}$ \\
\hline \multirow[t]{2}{*}{ |eeplot } & 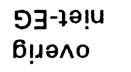 & $\begin{array}{l}9 \exists \\
6 ! 1 \ominus \wedge \circ\end{array}$ & $\begin{array}{l}\text { pue| } \\
\text {-גəpəN }\end{array}$ & [eepo] & 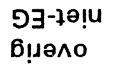 & $\begin{array}{l}\text { อコ } \\
6 ! \mu ә \wedge о\end{array}$ & $\begin{array}{l}\text { pue| } \\
\text {-גəpəN }\end{array}$ & & әроэ \\
\hline & \multicolumn{3}{|c|}{ рuердәрәN } & & & \multicolumn{2}{|c|}{ puouuu!!y } & 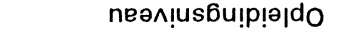 & -105 \\
\hline
\end{tabular}

166 L-066 L әр әррр!шә6

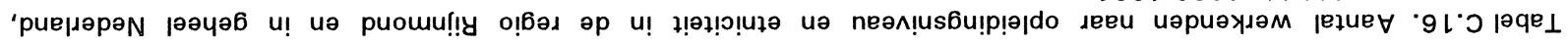

$\forall 0 y / S g o:$ :uodg

иәриәудәм 000' 2 иер дәри!щ $=\cdot$

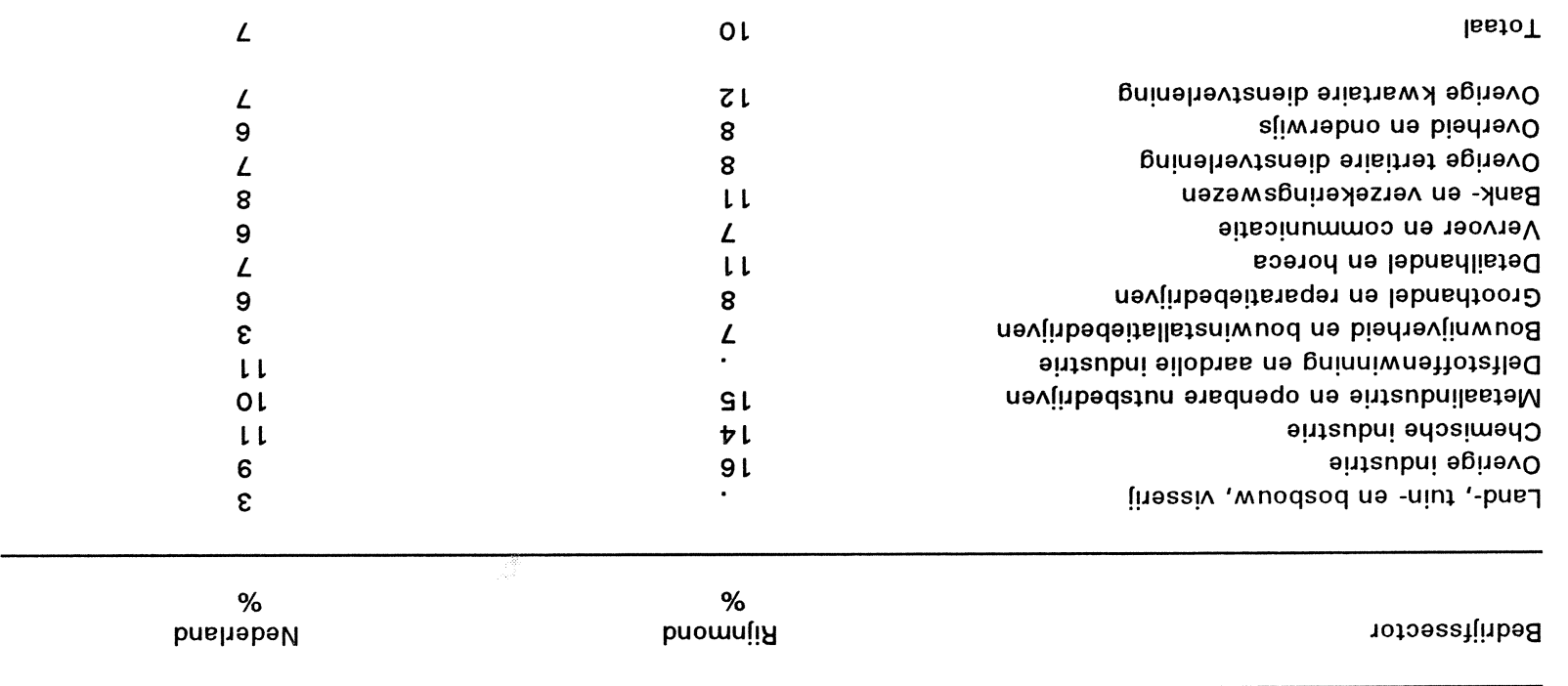

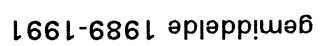

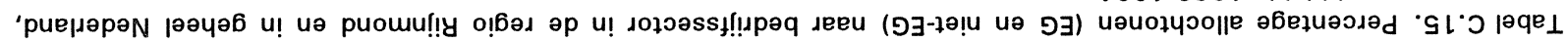




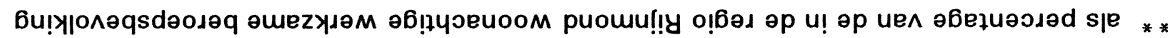

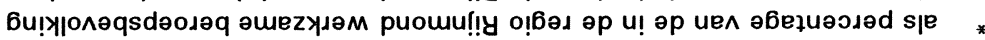
иәриәудәм $000^{\circ} Z$ uер дәри!山 $=$.

\begin{tabular}{|c|c|c|c|}
\hline 81 & $009^{\circ} Z L$ & $\nabla 2$ & $000^{\circ} \angle O L$ \\
\hline$\downarrow \downarrow$ & 000.8 & $8 \mathrm{l}$ & OOS'ヤl \\
\hline sて & $009^{\circ} \varepsilon\llcorner$ & $\angle Z$ & $000^{\circ} 91$ \\
\hline$\nabla \tau$ & $000 * 8$ & 乙ع & 000 て \\
\hline$\angle l$ & $000^{\circ} \varepsilon$ & $\tau \varepsilon$ & $000^{\circ} L$ \\
\hline Ol & $009^{\circ} t$ & 82 & OOS.9l \\
\hline Ol & $000^{\circ} t$ & Sl & $000 \div 9$ \\
\hline$\varepsilon 乙$ & 000.8 & 92 & $009^{\circ} 6$ \\
\hline 乙乙 & OOS's & $\varepsilon \varepsilon$ & 000.01 \\
\hline \multirow[t]{2}{*}{$\nabla \tau$} & $00 S^{\circ} t$ & 92 & $000 \% 9$ \\
\hline & & $9 \varepsilon$ & $009^{\prime} Z$ \\
\hline \multirow[t]{2}{*}{$\varepsilon \tau$} & 000.8 & 61 & $009^{\circ} 9$ \\
\hline & & $8 \mathrm{~L}$ & $009^{\circ} Z$ \\
\hline 82 & oOs' & & \\
\hline
\end{tabular}

ןeeto_ s!!mдәрuo uә p!әчдәло

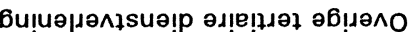
иәzәмsбu!

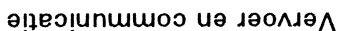
вәәдоч иә јәриечा!еґә0

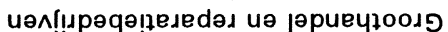
иә^!!

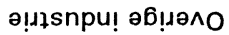

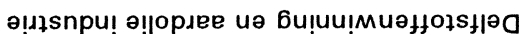

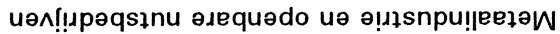

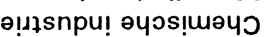

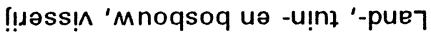

\begin{tabular}{|c|c|}
\hline $\begin{array}{ll}* * \% & \text { |ejuee } \\
\text { |əpuəd əpuee6 } 6 ! n\end{array}$ & $\begin{array}{l}\text { *\% |ejuee } \\
\text { |əpuəd әрuee6u! }\end{array}$ \\
\hline
\end{tabular}

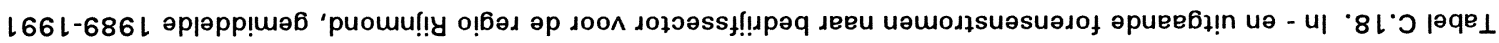

$\forall 0 y /$ sgo :uodg

\begin{tabular}{|c|c|c|c|}
\hline$\angle$ & Ol & ןeeło_ & \\
\hline Ol & い & $O M$ & 9 \\
\hline 9 & Ol & $\mathrm{OQH}$ & $\mathrm{s}$ \\
\hline$t$ & 9 & ogw & $66 t-10 t$ \\
\hline $\mathrm{OL}$ & 乙し & $O M \wedge / O \wedge \forall H$ & lot \\
\hline 9 & Ol & 087 & $66 \varepsilon-90 \varepsilon$ \\
\hline 6 & 6 & 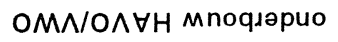 & \\
\hline$t l$ & 12 & $\begin{array}{r}\text { uə } 0 \wedge \forall W \\
\text { s!!Mرəpuos!seg }\end{array}$ & $\begin{aligned} l 0 \varepsilon \\
\tau^{\prime} L^{\prime} 0\end{aligned}$ \\
\hline $\begin{array}{c}\% \\
\text { рuе|дәрәN }\end{array}$ & $\begin{array}{c}\% \\
\text { puomul!y }\end{array}$ & neən!̣usbu!p!ə|ədo & $\begin{array}{l}\text { әроo } \\
-10 S\end{array}$ \\
\hline
\end{tabular}

L66 L-066 І әр|әрp!шә6

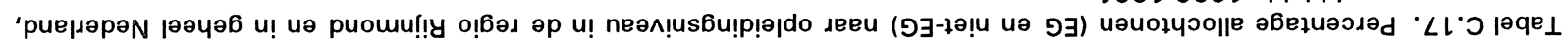




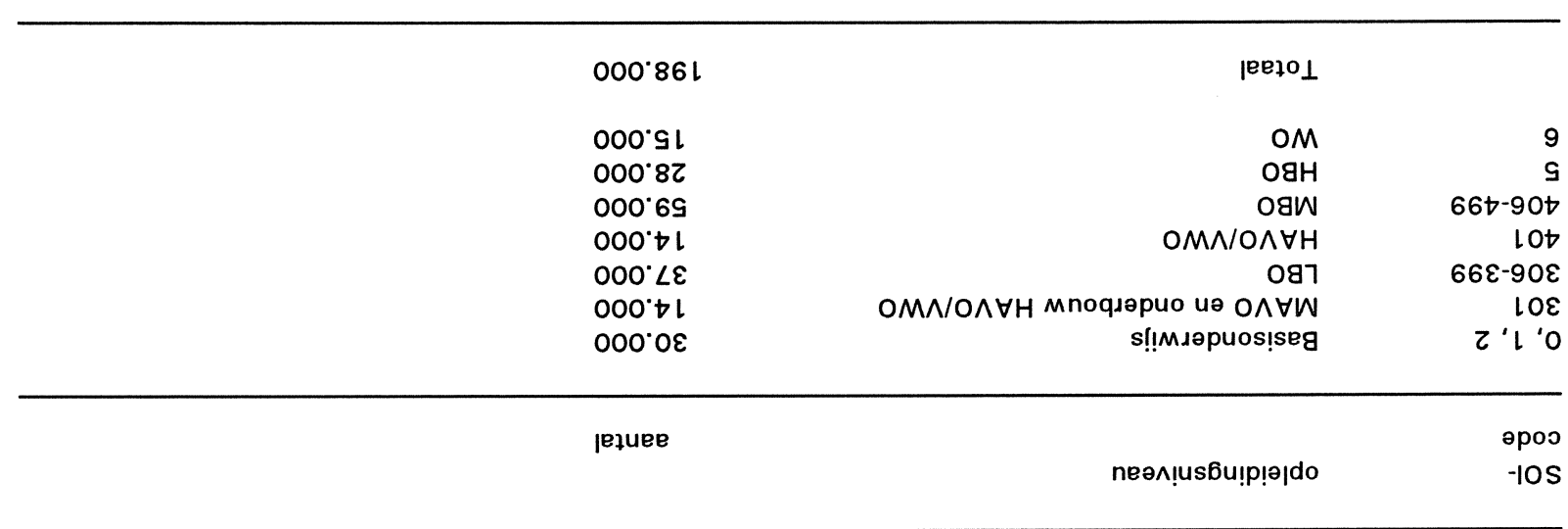

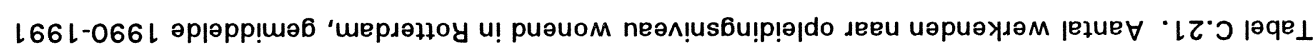

$\forall 0 y / S g 0$ :uodg

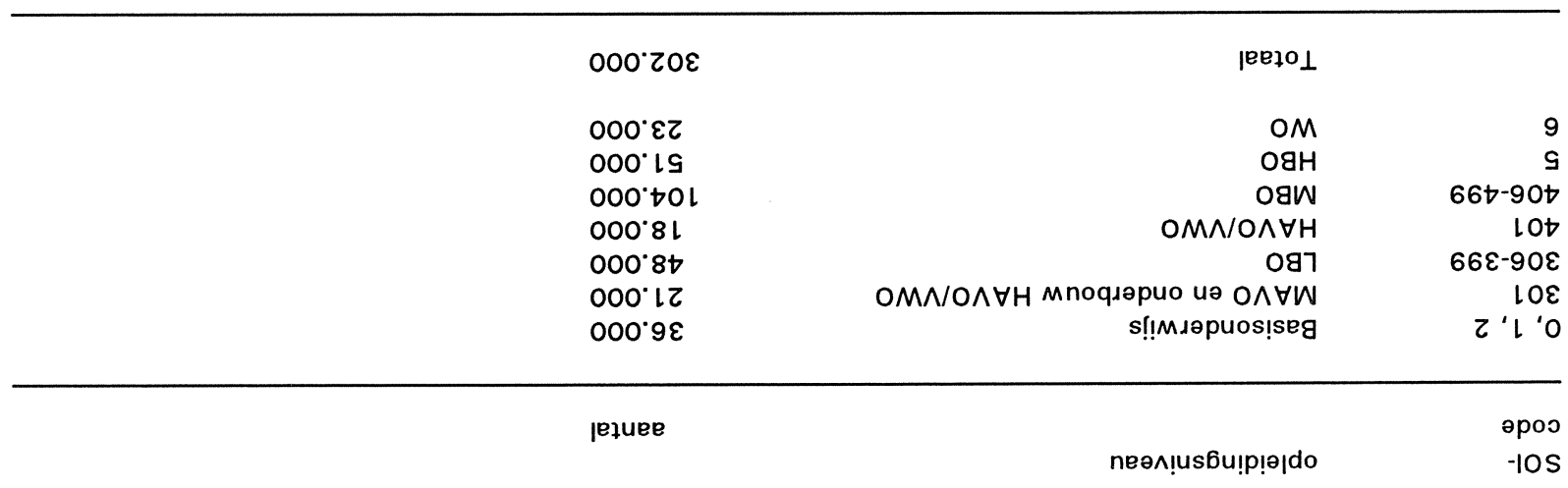

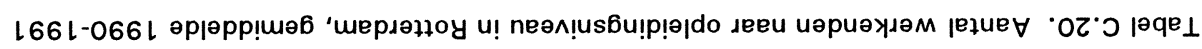

$\forall 0 y /$ sgo :uodg

\begin{tabular}{|c|c|c|c|c|c|}
\hline \multicolumn{6}{|c|}{ 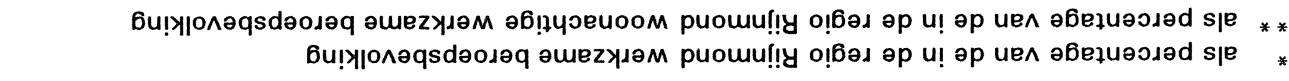 } \\
\hline 81 & $000^{\circ} \varepsilon L$ & $\triangleright 乙$ & $000 \cdot 901$ & \multicolumn{2}{|l|}{ ןęol } \\
\hline ૬ع & $000 \cdot 8$ & $9 t$ & $000^{\circ} \varepsilon l$ & $O M$ & 9 \\
\hline oz & 000 てl & $\dashv \varepsilon$ & $000^{\circ} \triangleright 2$ & ОЯН & S \\
\hline 81 & $000 \cdot 92$ & $\downarrow 乙$ & $0008 \varepsilon$ & ogw & $66 t-90 t$ \\
\hline$\angle l$ & $000 * t$ & ८乙 & $000 \div 9$ & $O M \wedge / O \wedge \forall H$ & lot \\
\hline Sl & 000 ZL & 81 & $000 \bullet 1$ & 087 & $66 \varepsilon-90 \varepsilon$ \\
\hline$\nabla l$ & $000^{\circ} t$ & 乙乙 & \multicolumn{2}{|c|}{$000^{\circ} \angle O M \wedge / O \wedge \forall H$ Mnoqдәрuo uә $O \wedge \forall W$} & \\
\hline てl & $000 \cdot 9$ & $\varepsilon\llcorner$ & $000 \%$ & s!!Mıәрuos!seg & 乙'l’o \\
\hline \multicolumn{2}{|c|}{$\begin{array}{ll}* * \% & \text { |едuee } \\
\text { |әрuәd әрuee } 6 \text { |!n }\end{array}$} & \multicolumn{2}{|c|}{ 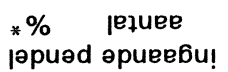 } & neə^!̣us6u!p!̣|do & $\begin{array}{r}\text { әроo } \\
-10 S\end{array}$ \\
\hline
\end{tabular}

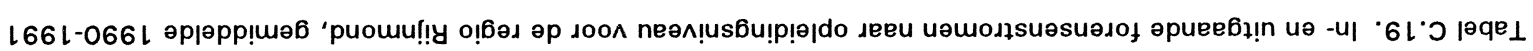




\begin{tabular}{|c|c|c|c|c|c|c|c|c|c|}
\hline & & & & & & & & \multicolumn{2}{|c|}{ чәриәудәм $000^{\circ} \varepsilon$ иер дәри!щ = } \\
\hline$\angle L$ & $000^{\bullet} \varepsilon \varepsilon$ & 6 & 00081 & 92 & $000.6 L$ & s乙 & $000 \cdot 9 L$ & |eełoL & \\
\hline ot & $000 \cdot 9$ & $\cdot$ & $\cdot$ & 87 & $000\llcorner L$ & $\varepsilon\llcorner$ & $000^{\circ} \varepsilon$ & $O M$ & 9 \\
\hline 81 & $000^{\circ} 9$ & $\cdot$ & $\cdot$ & $\angle \varepsilon$ & 000.61 & $\downarrow \tau$ & 000 てl & $\mathrm{OgH}$ & $\mathrm{s}$ \\
\hline$\angle \mathrm{l}$ & $000^{\circ} \mathrm{Ol}$ & Ol & $000 \cdot 9$ & 92 & $000^{\circ} \angle Z$ & $\varepsilon \varepsilon$ & $000^{\circ} \downarrow \varepsilon$ & ogw & $66 t-90 t$ \\
\hline 12 & $000^{\circ} \varepsilon$ & $\cdot$ & & 乙乙 & $000^{\circ} \nabla$ & 82 & $000^{\circ} 9$ & $O M \wedge / O \wedge \forall H$ & $10 t$ \\
\hline$\downarrow l$ & $000 \cdot 9$ & $\iota \iota$ & $000^{\circ} t$ & 61 & $\begin{array}{l}000^{\circ} 6 \\
000^{\circ} 9\end{array}$ & $\begin{array}{l}\varepsilon \tau \\
6 Z\end{array}$ & $\begin{array}{l}000 \cdot 1 \downarrow \\
000 \cdot 9\end{array}$ & 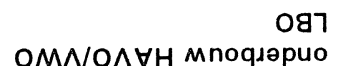 & $66 \varepsilon-90 \varepsilon$ \\
\hline Ol & $000^{\circ} \varepsilon$ & Ol & $000^{\circ} \varepsilon$ & $\downarrow l$ & $000 \cdot 9$ & $\angle L$ & $000 \cdot 9$ & $\begin{array}{r}\text { uə } 0 \wedge \forall W \\
\text { s!!Mıәрuos!seg }\end{array}$ & 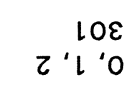 \\
\hline$\%$ & $\begin{array}{l}\text { |equee } \\
\text { [eełoł }\end{array}$ & $\begin{array}{c}\% \\
\text { puouuu!!y }\end{array}$ & $\begin{array}{l}\text { jejuee } \\
\text { fsad deeu }\end{array}$ & $\%$ & $\begin{array}{l}\text { lejuee } \\
\text { [ee]of }\end{array}$ & $\begin{array}{c}\% \\
\text { puouuu!!y }\end{array}$ & $\begin{array}{l}\text { |ełuee } \\
\text { Isad uen }\end{array}$ & & әроэ \\
\hline \multicolumn{4}{|c|}{ |әрuәd әрuee6\}!̣ } & \multicolumn{4}{|c|}{ ןpuəd әрuee6u! } & neәл!̣us6u!p!ə|do & -105 \\
\hline
\end{tabular}

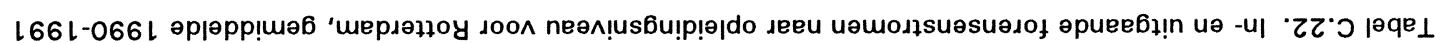

